الأخطاء اللغوية في أسئلة الاختبارات بجامعة القصيم في ضوع علم اللغة

\title{
التطبيقي
}

"الاختبارات الورقية والإكترونية" الاكتور جمال مصطفى سيدأحمد شتا لإنا

أستاذ اللغويات المساعد بكلية العلوم والآداب بعنيزة جامعة القصيم

imsheta@gmail.com

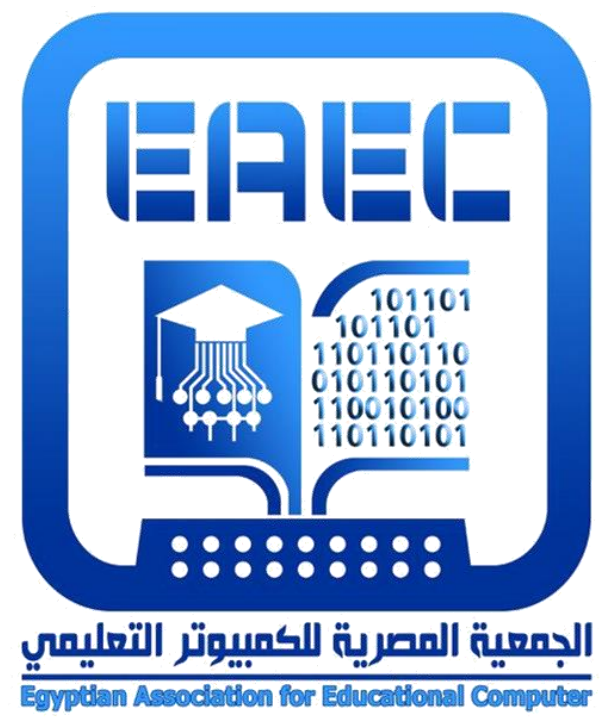

المجلة العلمية المحكمة للجمعية المصرية للكمبيوتر التعليمي

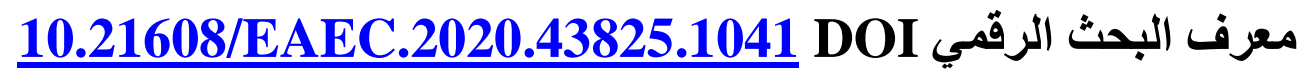
المجلا الثامن - العدد (الثاني)- الطبعة الأولي مسلسل العدد 16 - ديسمبر 2020 - لئل رقم الإيداع بدار الكتب 24388 لسنة 2682 ISSN-Online: 2682-2601 ISSN-Print: 2682-2598

http://eaec.journals.ekb.eg https://eaec-eg.com
موقع المجلة عبر بنك المعرفة المصري موقع الجمعية العنوان البريدي: ص.ب 60 الأمين وروس 42311 بورسعيد - مصر

\begin{tabular}{|c|c|c|}
\hline & $2020-09-22$ 16:46:22 & تاريخ الإرسال \\
\hline & $2020-10-13$ 06:00:41 & تاريخ المراجعة \\
\hline & $2020-10-22$ 16:23:56 & تاريخ القبول \\
\hline & 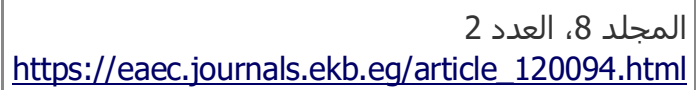 & عرض المقال المنشور \\
\hline
\end{tabular}
(c) $(\mathrm{i}) \bigodot_{\mathrm{BY}}$ $=289=$ 
مجلة الجمعية المصرية للكمبيوتر التعليمي

$=290=$

المجلد الثامن ـ العدد الثاني ـ مسلسل العدد (16) ـ ديسمبر 2020 
مجلة الجمعية المصرية للكمبيوتز التعليمي

\section{شيكر وعرفان}

يتقدم الباحث بجزيل الثكر لجامعة القصيم- مُمثُّة بعمادة البحث العلمي- على

دعمها المادي لهذا البحث، تحت رقم(2018-S-14-1-3824) خلال السنة الجامعية 1440هـ/2018م

Thanks and gratitude

The researcher extends his thanks to Qassim University represented by the Deanship of Scientific Research - for its financial support for this research, under No. (3824-S-14-12018) during the academic year $1440 \mathrm{H} / 2018$ AD 
مجلة الجمعية المصرية للكمبيوتر التعليمي 
مجلة الجمعية المصرية للكمبيوتر التعليمي

\section{الأخطاء اللغوية في أسئلة الاختبارات بجامعة القصيم في ضوء

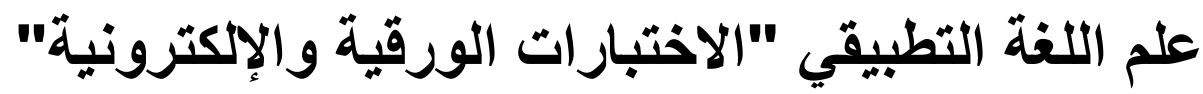

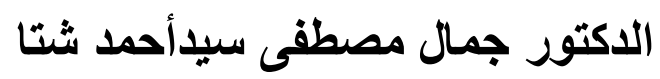

أستاذ اللغويات المساعد بكلية العلوم والآداب بعنيزة - جامعة القصيم

ملخص البحث

تهدف الدراسة إلى إيجاد السبل نحو دقة صياغة أسئلة الاختبار ات وصحتها اللغوية؛

وصولا إلى فهم الطالب الصحيح لأسئلة الاختبارات؛ وسعيا إلى تحقيق الجودة الثيادة الثاملة للمنتَج

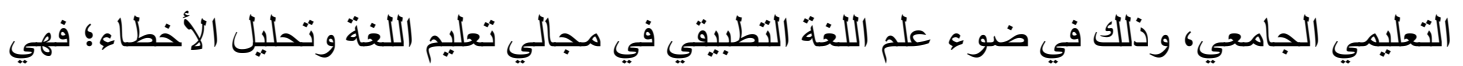

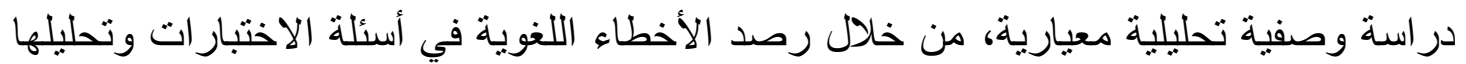

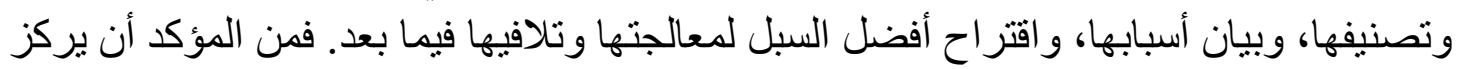

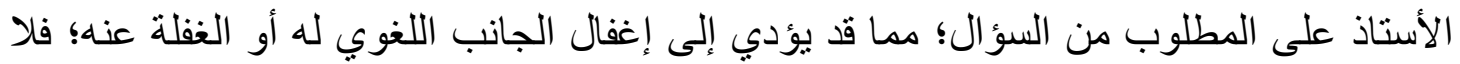

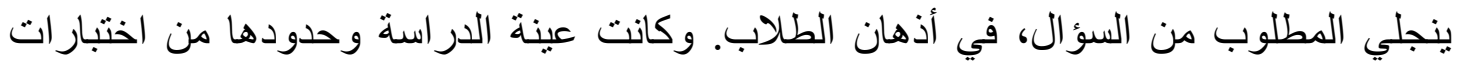

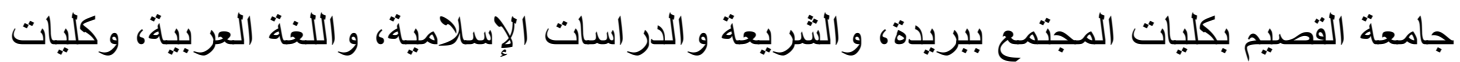

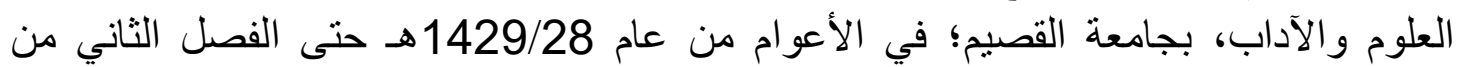

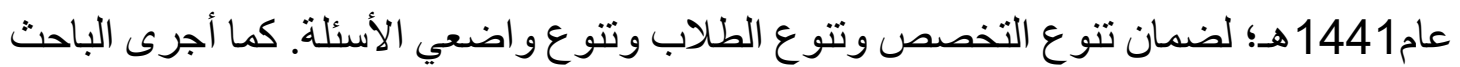

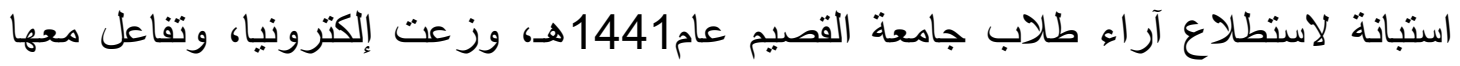

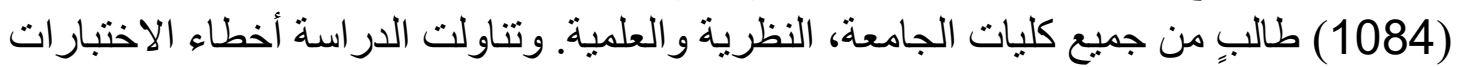

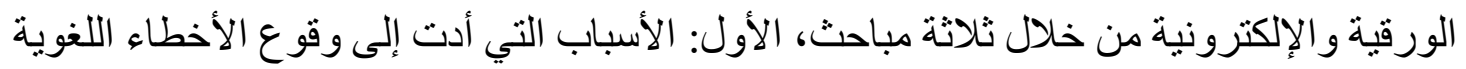

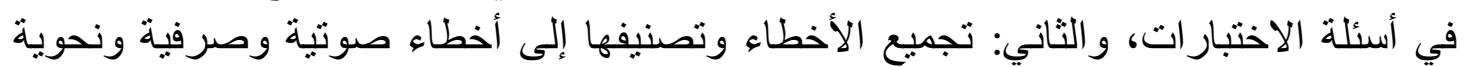

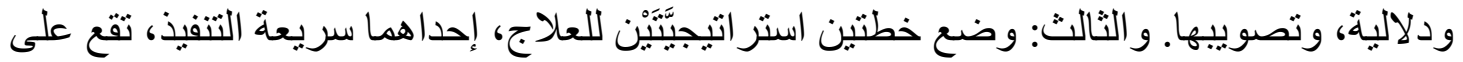

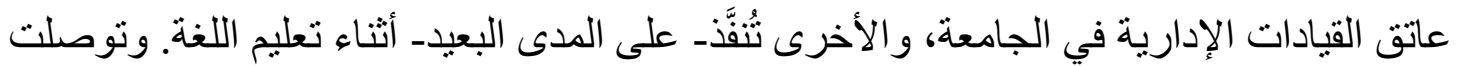

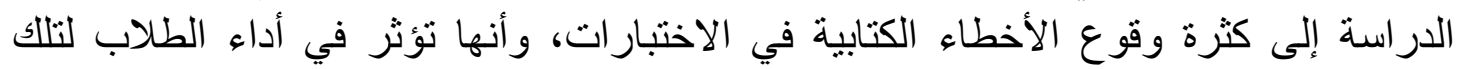

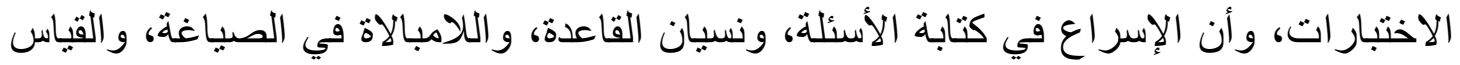

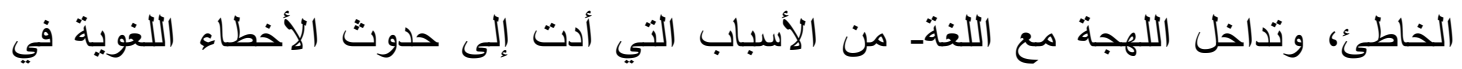
الاختبار ات، وبنت على ذلك سبل علاجها.

الكلمات المفتاحية: الاختبارات، الإلكترونية، الأخطاء، اللغويات التطبيقية.

مقدمة

ورد في الحديث النبوي: "إن أوَّلَ ما خلقَ اللهُ القلُ، فقال له: اكتُبْ، قال: ربَّ، وماذا أكثُبُ؟

قال: اكتُبْ مقاديرَ كل شيء حتى تقومَ الساعةُ" (أبو داود السجستاني، 209/10/03200م:ه6/7، 


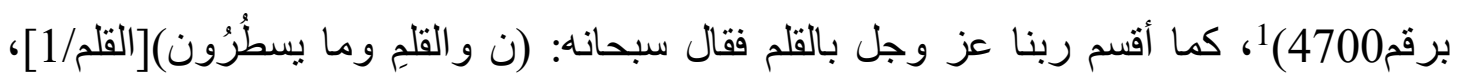

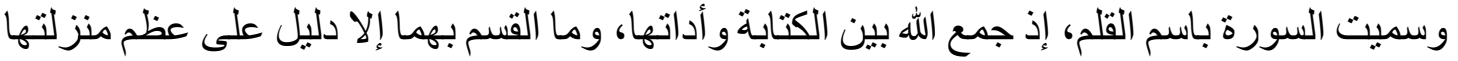

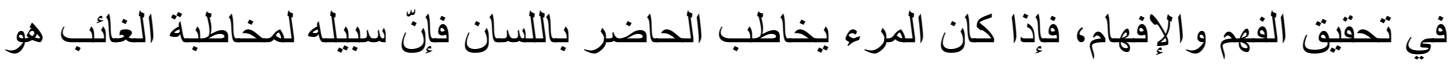
القلم، ووكّل الله تعالى بكل إنسان حفظة من الملائكة يكتبون عليه أعماله الحسنة والسيئة، التي

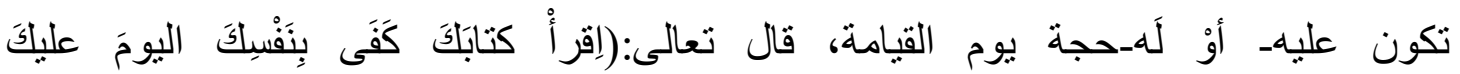
حَسييًا)]الإسر اء/14]. فدل ذلك على أهية الكتابة التي هي وسيلة من وسائل نقل العلم وحفظه،

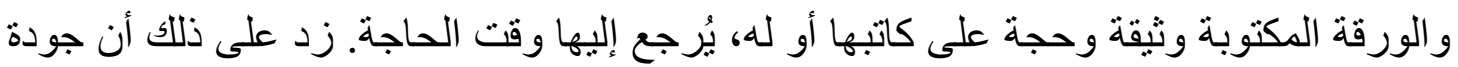
الكتابة ترفع قدر الكاتب، وتسهل له النجاح في نيل المقاصد، وبلوغ المآرب. و إذا كان الكلام المنطوق معرضًًا للنسيان فإنّهــ مكتوبًا- باق في كل زمان ومكان. (حيدرالثلاه،2012م: ص316). فالكتابة تخلّد المعاني في المباني و إن غاب مُنشؤها، وفي هذا المعنى قال أحده:

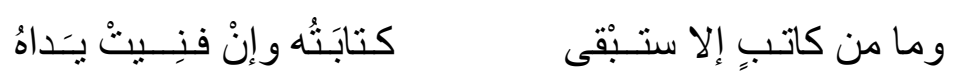

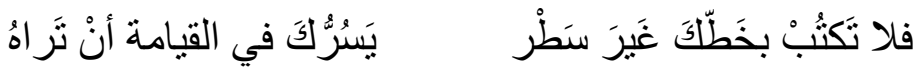

ومن المعلوم ضرورةً أن الاختبار ات وثيقة رسمية، لها صفة قانونية، لذا فالحرص على

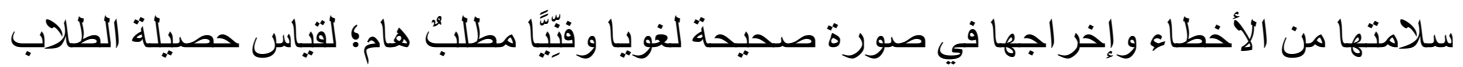
العلمية وقدر المعلومات التي أفادو ها في المقرر، من ناحية، ولتيسير فهمه الأسئلة وإجابتها بشكل

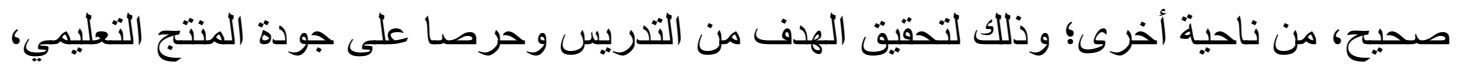

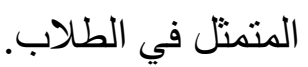

وقد وجدتُ-ـ من خلال اطلاعي على أسئلة الاختبار ات، أثناء عملي بلجان الاختبار ات في جامعة القصيم، خلال عِقد من الزمنـ أخطاءً لغوية كثيرة، مما دفعني إلى التفكير في طريقة عاجلة

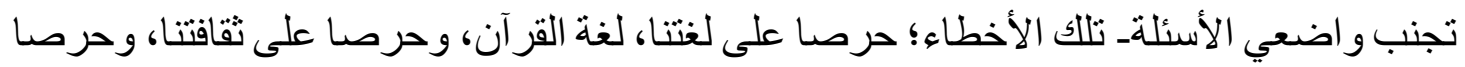

1- رُو عي في توثيق المصادر و المر اجع الترتيب المعتمد من الجمعية الأمريكية لعلم النفس، الإصدار السابع، إلا أن بعض المر اجع القبيمة أُشُشُر أصحابها بالكنية و اللقب، فذكرنا كنيته ولقبه. 
مجلة الجمعية المصرية للكمبيوتز التعليمي

على هويتنا، وحرصا على أن يفهم الطلابُ الأسئلةً فهما صحيحًا؛ لتحصيل أعلى المعدلات؛ ووصو لا إلى تحقيق الجودة الثاملة في التعليم الجامعي، وتحسين المخرجات.

لذا فقد استعنت بالله لمعالجة هذا الموضوع، ولأنبّهُ زملائي -خصوصيًا غير المتخصصين منهم- على هذا الذطر الكامن، وكذلك كل أعضاء هيئة التدريس في جامعة القصيم؛ ليضعو ا هذه اللغة في مكانها اللائق، ويعيدوا إليها شبابها، من خلال الاعتناء بصياغة أسئلتهم، ودقة ألفاظها، وجز الة أسلوبها؛ و إحكامها؛ لتحصيل المقصود من تللك الاختبار ات؛ ومساعدة الطلاب على الإجابة الصحيحة؛ مما ينعكس بالإيجاب على الإقبال على المقررات الدر اسية، و الاستفادة منها في تحصيل العلم! وتقتصر الدراسة هنا على تناول قضية الأخطاء من الجانب اللغوي فقط، أما الجانب التربوي فله أهله ودر اساته الخاصة بها، إذ إنه ليس من مجال در استنا هذي.

\section{أهمية الاراسة:}

تكمن أهمية هذه الدراسة في محاولة إيجاد حلول عملية ناجعة تؤدي إلى تلافي الأخطاء اللغوية في أسئلة الاختبار ات، من خلال الاستفادة من دراسات علم اللغة التطبيقي، في تحليل الأخطاء، وبيان أسبابهاوطرق علاجها. وسبب الاهتمام بصياغة أسئلة الاختبار ات ما يترتب على الخطأ فيها من غموض المراد من السؤال-غالبا-لدي الطلاب؛ مما يؤدي إلى تتكُّهم الطريق الصحيحة في إجاباتهم.

مشكلة البحث:

و أما عن مشكلة الدر اسة فتنحصر في كثرة الأخطاء اللغوية الواردة في اختبار ات جامعة القصيم الورقية والإلكترونية، التي اطلع عليها الباحث أثناء عمله بلجان الاختبار ات النهائبة، و اطلاعه على الاختبارات الإلكترونية الخاصة ببعض زملائه في الجامعة؛ بعد انتهاء تلك الاختبار ات. فانبرت الدراسة لمحاولة معرفة تأثنير الأخطاء اللغويةـ الواقعة في اختبار ات جامعة القصيم النهائيةـ في طلاب الجامعة، من حيث فهمه للمطلوب من السؤ ال، ومن حيث إجاباتهم عن $=295=$ 
مجلة الجمعية المصرية للكمبيوتز التعليمي

تللك الأسئلة. كما تكمن مشكلة الدر اسة أيضا في معرفة الأسباب الحقيقية المؤدية إلى وقوع الأخطاء اللغوية في الاختبار ات النهائية، وطرق علاج تللك الأخطاء من خلال علم اللغة التطبيقي، ونظرية تحليل الأخطاء.

\section{تساؤلات البحث:}

\section{يطرح البحث التساؤلات الآتية للوصول إلى التتائج المرجوة:}

1- ما تأثثر الأخطاء اللغوية في فهم الطلاب للأسئلة؟ 2- ما الأسباب التي أدت إلى وقوع الأخطاء اللغوية في أسئلة الاختبار ات؟

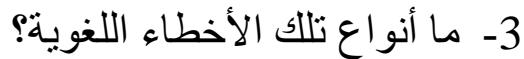
4- ما الوسائل الكفيلة بمعالجة هذه الأخطاء أو الحد منهاء

\section{أهدافـ البحث:}

للبحث أهداف عامة و أهداف خاصة، أما الأهداف العامة فتتمثل في:

1- الحفاظ على الفصحى بصفتها لغة القرآن ولغة الثقافة و عنوان الهوية العربية. 2- الاهتمام بورقة أسئلة الاختبار ات باعتبار ها وثيقة رسمية.

3ـ تحقيق الجودة في التدريس؛ باعتبار أن الاختبار ات تقيس مدى استيعاب المقرر التعليمي. و أما الأهداف الخاصة فتثمثل في:

1- التأكبد على أن المعنى مرتبط بصحة السؤ ال لغويَّا. 2- تحديد الأخطاء اللغوية وتصنيفها. 3- تحديد أسباب وقوع الأخطاء اللغوية في اختبار ات جامعة القصيم الورقية والإلكترونية، من خلال تحليل الأخطاء الواردة. 4- وضع استر اتيجية علاج سريعة لمعالجة تللك الأخطاء في ضوء علم اللغة التطبيقي ونظربة تحليل الأخطاء.

5- وضع استراتيجية علاج على المدى البعيد لمتعلمي اللغة، في ضوء علم اللغة التطبيقي ونظريةتحليل الأخطاء. 
تندرج هذه الدراسة تحت المنهجين الوصفي التحليلي والمعياري؛ بعد استقر اء عينة كبيرة من الاختبار ات النهائية في سَبع من كليات جامعة القصيم تضم أقسامًا علمية ونظرية، ثم تصنيف هذه الأخطاء، وتحليلها، ومعرفة أسبابها، ووضع الحلول لعلاجها؛ وذللك في ضوء علم اللغة التطبيقي. هذا ولم يشر الباحث إلى الألفاظ والتر اكيب التي أجاز ها مجمع اللغة العربية بالقاهرة، ولم يَعُدَّها من قبيل الأخطاء، وسنشير إليها في المبحث الثاني؛ إن شاء الله.

\section{عينة الار اسة وحدودها الزماتية و المكاتية:}

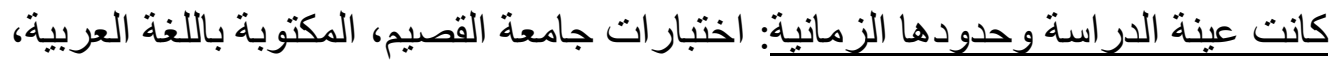
خلال ثلاثة عشر(13) عامًا در اسيَّا جامعيَّا، من عام (1429/28هـ) حتى نهاية الفصل الثاني من عام(1441هـ)، شملت المقرر ات العلمية والأدبية، في تخصصات الكيمياء، و الفيزياء، و الأحياء، و الرياضيات، وعلوم الحاسب، وتقنية المعلومات، و الإدارة، و المحاسبة، و الموارد البشرية و الاقتصاد، و التربية، و علم النفس، و التاريخ، و اللغة العربية، و الثريعة بفروعها، والأنظمة، و الثقافة الإسلامية. وحدود الدراسة المكانية: كلية المجتمع ببريدة، وكلية الثريعة و الدراسات الإسلامية للطلاب و الطالبات، وكلية اللغة العربية، وكليات العلوم و الآداب في بريدة و عنيزة و الرس و المذنب، بجامعة القصيم. وقد حرص الباحث على الاطلاع على أور اق الأسئلة الموثقة بشعار جامعة القصيم، المسجل فيها بيانات الاختبار. وقد جمع الباحث نحوًا من سبعين وأربعمائة(470) اختبارِ من موقع (كويزات) الإلكتروني، يرفع عليه طلاب الجامعات السعودية اختبار اتهم، ومنها اختبار ات جامعة القصيم، على هذا الر ابط: (hittps://koizat.com/categorr/\%od8\%ac\%od8\%a7\% إضافة إلى خمسين(50) اختبارًا نهائيًا، للفصل الدراسي الثاني عام(1440/39هـ) بكليتي المجتمع ببريدة، و العلوم و الآداب بعنيزة، وسبعة وستين(67) اختبارًا نهائَّا، ورقيَّاً و إلكترونيَّا، للفصلين الدر اسيَيْنِ الأول والثاني عام (1441/40 هـ) بكلية العلوم و الآداب في عنيزة، فيكون مجموع ما اطلع عليه الباحث نحوًا من سبعة وثمانين وخمسمائة(587) اختبارِ ، منها الاختبار ات الإلكترونية النهائية و الفصلية، واختبار ات الدراسات العليا، لكن أكثر ها من الاختبار ات النهائية. وكان الهدف من اختيار تللك الكليات تنوع التخصص وتنوع الطلاب وتتوع و اضعي الأسئلة. $=297=$ 
مجلة الجمعية المصرية للكمبيوتر التعليمي

و السبب الذي جعل الباحث يضم إلى عينة الدراسة الاختبارات الإلكترونية الثنهرية والنهائية، أنها

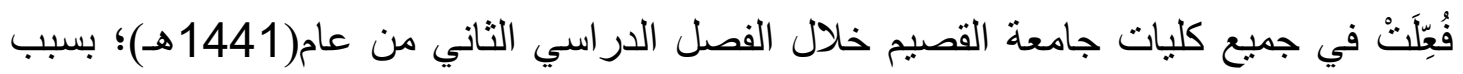
جائحة انتشار (فيروس كورونا)، فكان لابد للار اسة أن تتظر فيها أيضًا.

\section{تعريف مصطلحات الدراسة:}

ـالأخطاء اللغوية: (الأخطاء) جمع، مفرده (الخطأ)، ويُقصَّد به ما خالف قواعد اللغة العربية

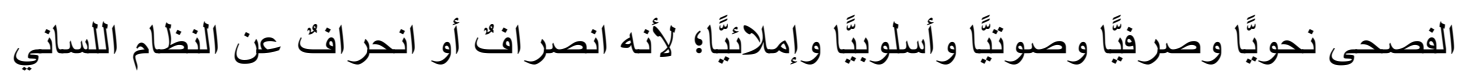

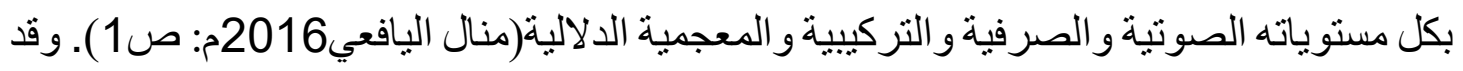

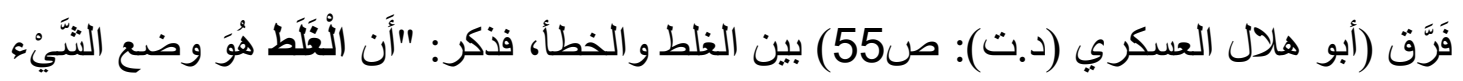

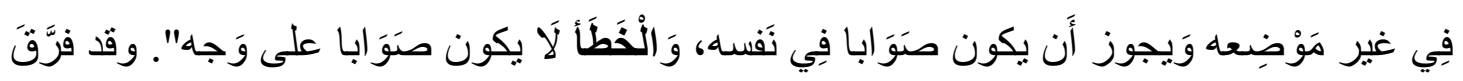
(كوردر) بين (الأغلاط) و(الأخطاء)، عند متعلم اللغة، بقوله: "فتنشير (الأغلاط) إلى خطأ في الأداء

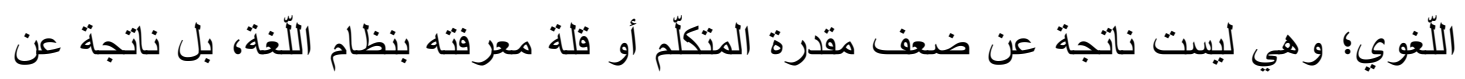

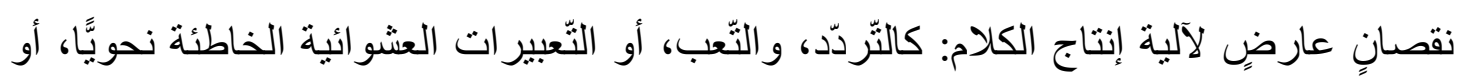

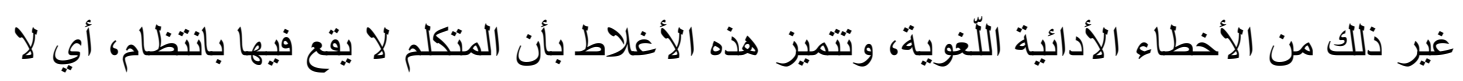

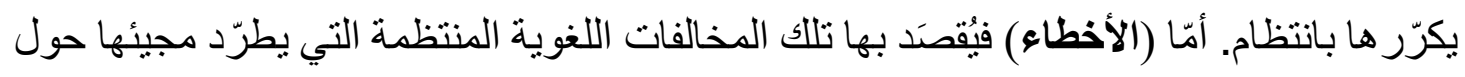

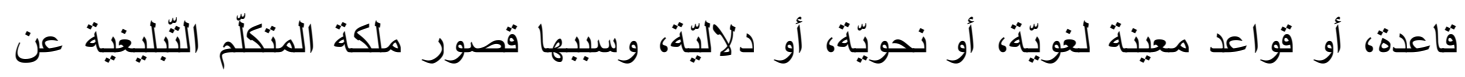

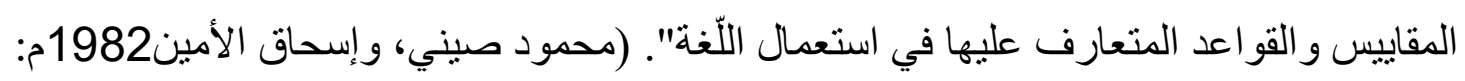

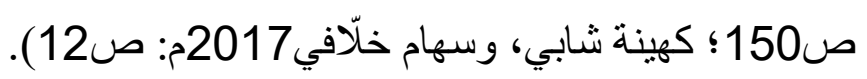
ـ الاختبارات(tests): يُقصَّد بها- هناـ الأسئلة التحريرية الشهرية و النهائيةــ الورقية، شاملة

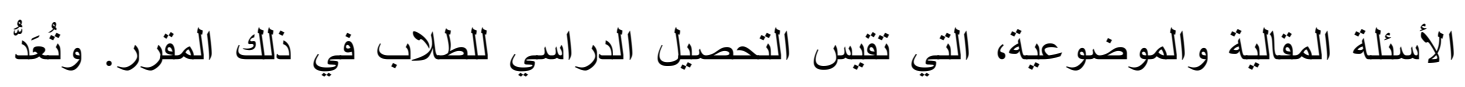

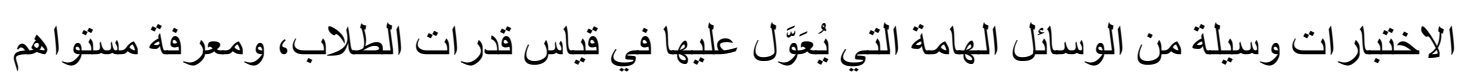

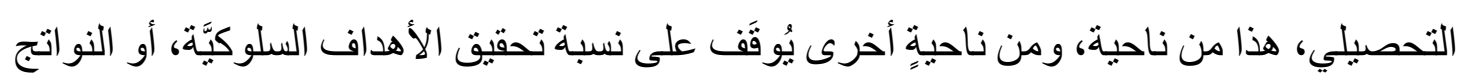

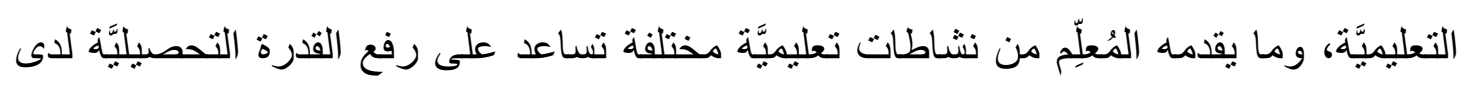

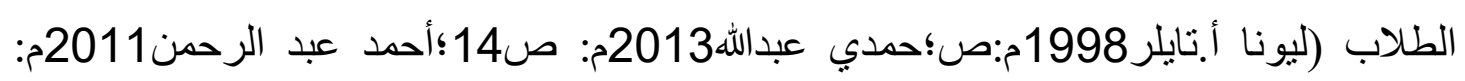


مجلة الجمعية المصرية للكمبيوتر التعليمي

ـ الاختبارات الإكترونية(Electronic Tests): تُعد الاختبار ات الإلكترونية أحد وسائل القياس العيد

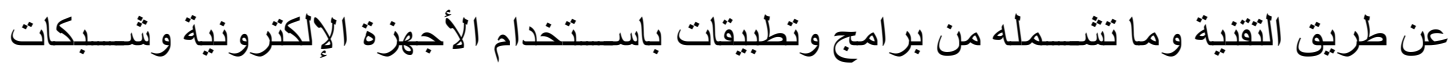

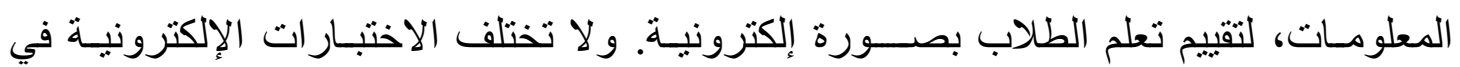
مضمونها عن الاختبار ات التقليدية، بل هي تعديل وتطوير في شكلها ووسائط تصميمها وطريقة عرضهها، لتتو افق مع الأجهزة الإلكترونية وشبكات المعلومات و البرمجيات الخاصـة بها و التقييم

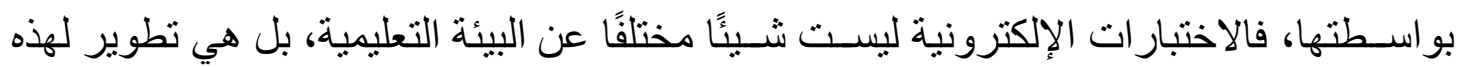

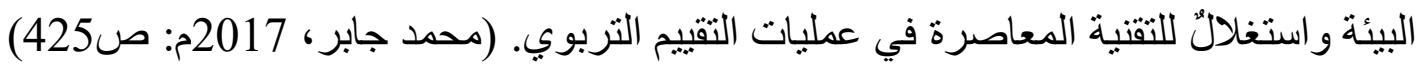
ويعرف مورا وآخرون Mora, et al(2012, p. 733 الاختبارات الإلكترونية بأنها:

وسيلة لتقييم مستوى التعلم لدى الدارسين بصورة إلكترونية من خلال أجزةة الكمبيوتر و الأجهزة الذكية وشبكة الإنترنت؛ لتحقيق السر عة في تصميم وبناء الاختبار ات وتصحيحها وتقديم التغذية المرتجعة.

ويُعرف لامساس وآخرون ( Llamas, et al (2013, p. 77 الاختبار ات الإلكترونيـة

بأنها: عملية تقيبم مدعمة بالوسـائط المتعددة تتم عبر وسـائل التواصـل و والتقنيات عن بعد؛ لتحديد مســتوى تقدم المتعلمين في مقرر ما، ويتم التحليل الإلكتروني للنتائج ومعالجتها عبر التقنية

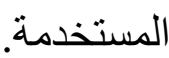

فالاختبار ات الإلكترونية تُعد وســيلة هامة من وســائل التقويم في مختلف المؤسـســـات

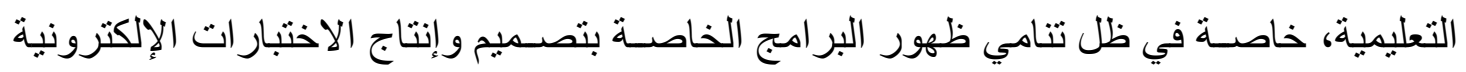

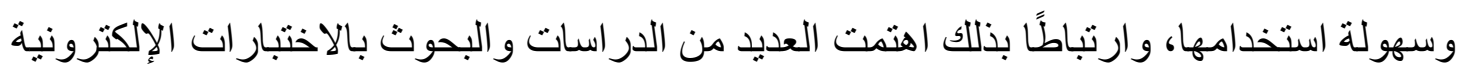

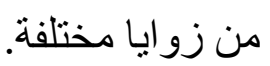
وقد تتاولت بعض الدراسات السابقة الضوابط والمعايير الدتعلقة بتصميم الاختبارات الإكترونية وإنتاجها؛ ومنها دراسات كل من: (أسماء محمود، 2011؛ أيمن الجوهري، 2011؛ إيناس مندور، 2013) و( Cigdem \& Oncu, 2015; Alonso \& Yuste, 2015 و والتي من توصلت إلى مجمو عة من المعايير التربوية والفنية اللازمة لتصميم و إنتاج الاختبار ات الإلكترونية، والتي أوصت بأهمية مراعاة الجوانب اللغوية عند تصميم هذه النوعية من الاختبارات. و الاختبارات الإلكترونية قائمة على أدوات التقويم في نظم إدارة التعلم الإلكتروني بشكل يساعد التهات 
مجلة الجمعية المصرية للكمبيوتز التعليمي

على اتخاذ القرار حول استخدامها عند التعامل مع بيئة التعلم الإلكتروني والتعليم من بعد.(عبد الرحمن سالم،2020م: صك606).

وقد استخدمت الدر اسة الحالية الاختبار ات الإكترونية الخاصة بنظام إدارة التعلم الإلكتروني المعتمـــ بجـامعـة القصــيم (black board). للفصـــل الــدراســي الثـاني من العـام الجامعي(1441/40هـــــ؛ حيث كانت جميع الاختبار ات الثـــرية والنهائية إلكترونية؛ نظرًا؛ للظروف التي مر بها العالم من انتشـار فيروس(كوفيد-19) المستجد، وما فرضته على العالَم من التباعد الاجتماعي و الانعز ال القسري.

ـ علم اللغة التطبيقي، أو اللسانيات التطبيقية(Applied Linguistics) هو أحد العلوم التي نتجت عن ظهور "علم اللغة" (Linguistics) في أو ائل القرن

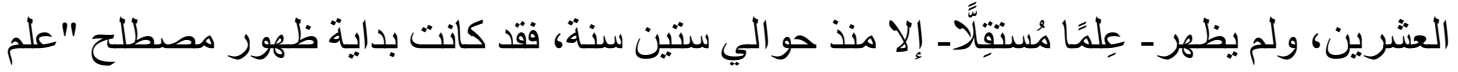

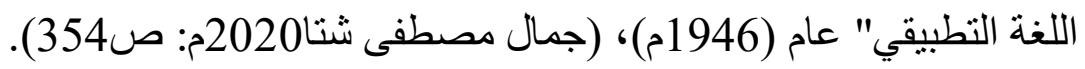
تعريف علم اللغة التطبيقي: لم يتفق علماء اللغة على تعريف قاطع لعلم اللغة التطبيقي، و لا لطبيعته، حتى إن بعضهم أنكر أن

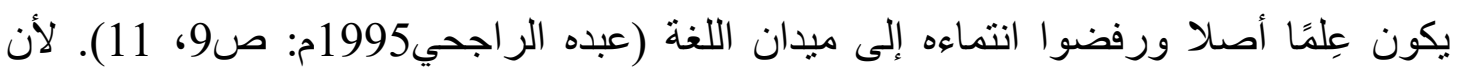
مجالاته عديدة، منها علم اللغة النفسي، علم اللغة الاجتماعي، تعلم اللغة الأولى وتعلميها، تعليم اللغة الكانة

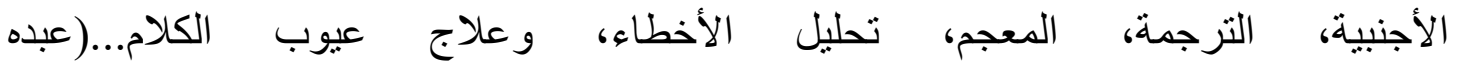

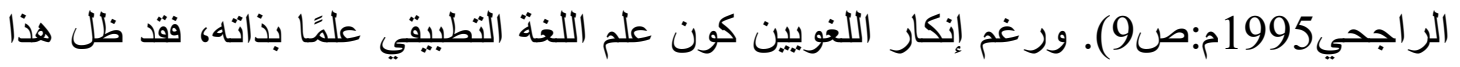

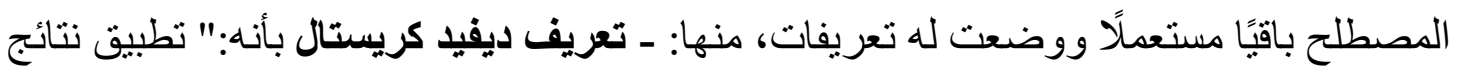
المنهج اللغوي وأساليبه الفنية في التحليل والبحث في ميدانٍ غير لغوي، ثم بعلق على التعريف قائلا: و علم اللغة بهذا المعنى ما هو إلا وسيلة لغاية معينة أكثر منه غاية في ذاته" (جلايلي

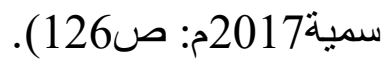

-تعريف مازن الوعر بأنه: "علم يبحث بالتطبيقات الوظيفية البراغماتية التربوية للغة من أجل تعليمها وتعلمها، للناطقين بها ولغير الناطقين بها، وييحث أيضا بالوسائل البيداغوجية [التربوية]

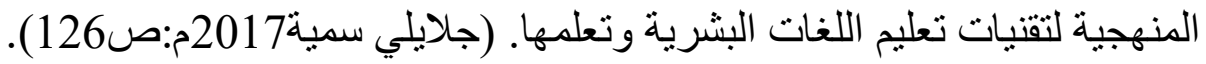


مجلة الجمعية المصرية للكمبيوتر التعليمي

ـتعريف هـ. دوجلاس براون: بأنه عبارة عن استخدام منهج النظريات اللغوية ونتائجها في بعض المشكلات ذات الصلة باللغة، وذللك في ميادين غير لغوية، وحقل هذا العلم شديد الاتساع يضم تعليم اللغات الأجنبية، أمر اض الكلام، الترجمة، فن صناعة المعاجم، و الأسلوبية وتعليم القراهة و غير ذلك (هـ. دوجلاس بر اون1994م:ص172-172؛ جلايلي سمية2017م: صندم:126). نستخلص مما سبق أن مجالات علم اللغة التطبيقي هي: تعلم اللغة الأولى وتعليهها، وتعليم اللغة الأجنبية، التعدد اللغوي، والتخطيط اللغوي، وعلم اللغة الاجتماعي، وعلم اللغة النفسي، و علاج أمر اض الكلام، و الترجمة، و المعجم، و علم اللغة التقابلي، و علم اللغة الحاسوبي، و أنظمة الكتابة وتحليل الأخطاء ... (عبده الراجحي1995م: ص9/ شارل بوتون(د.ت): ص7؛ جلايلي

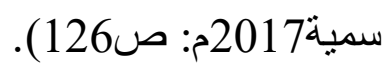

فيغلب على علم اللغة التطبيقي مجال تعليم اللغة، سـواء لأبنائها أو لغير هم، أي اللغة الأم أو اللغة الأجنبية، كما أن من مجالاته تحليل الأخطاء. (محمود فهمي حجازيكئ1992م: صك3؛

$$
\begin{aligned}
& \text { س. بيت كوردر1976م: ص64) } \\
& \text { إجراعات الدراسة: }
\end{aligned}
$$

عمل الباحث على جمع أكبر عدد من أسئلة الاختبار ات التحريرية لسبع كليات في جامعة القصيم، شملت كليات متنو عة في منطقة القصيم (بريدة- عنيزة- الرس- البكيريةـ المذنب- عقلة الصقور )، وشملت تلك الاختبارات التخصصات التطبيقية و النظرية، اللغوية وغير اللغوية، والاختبارات الورقية الثهرية والنهائية، و كذللك الإلكترونية بنظام التعلم الإلكتروني(black board)؛ خلال(13) عامًا من عُمْر الجامعة. - اطلع الباحث على كل الاختبار ات في الفترة المشار إليها وفي الكليات المحددة، و استخرج منها الأخطاء اللغوية الواقعة في الألفاظو التر اكيب و الأساليب، وصنفها حسب أنو اعها. - أجرى الباحث استطلاعًا لآراء طلاب جامعة القصيم، حول أسئلة الاختبارات، عام(1441هـ)، وكان الهدف من الاستطلاع التأكد من إحدى مشكلات الدراسة، وهي تأثنير الأخطاء اللغوية في فهم الطلاب لأسئلة الاختبار ات. - لل الباحث الأخطاء الواردة في الاختبار ات، في ضوء علم اللغة التطبيقي ونظرية تحليل الأخطاء. 
مجلة الجمعية المصرية للكمبيوتز التعليمي

- وضع الباحث استراتيجيتين لعلاج أخطاء أسئلة الاختبار ات المستقبلية؛ واحدة عاجلة، و الأخرى تُطبق على المدى البعيد أثناء تعليم اللغة؛ وفقًا لعلم اللغة التطبيقي وتعليم اللغة.

أما من ناحية استطلاع ر أي الطلاب فقد وُزِ ع الاستطلاع إلكترونيا، وتفاعل معه (1084) طالب: من جميع كليات الجامعة، النظرية والعلمية، بجميع المستويات الدر اسية، وقد صبغت الاستبانة من (14) فقرة، تم تحكيمها من أستاذين في مجال التخصص التربوي وتكنولوجيا التعليم، طُلب من كل طالب رأبه فيها (موافق بشدة/ موافق/ غير موافق/ غير موافق بشدة)، وكان الهدف منها التأكد من وجود المشكلة التي تتناولها هذه الدراسة، وكانت آراء الطلاب على النحو التالي:

\section{جدول(1) عبارات الاسنبانة والنسبة المئوية للردود عليها}

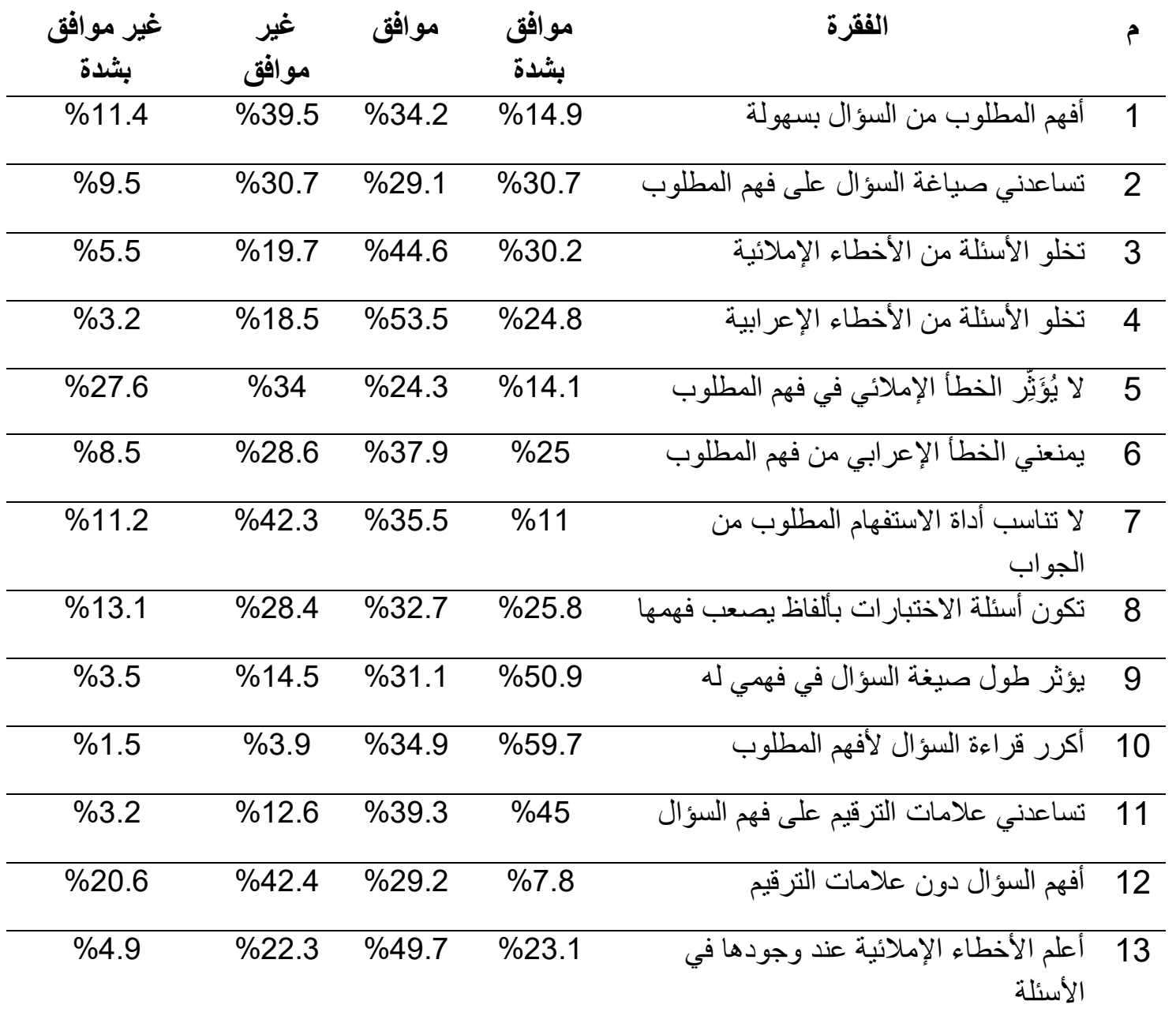


مجلة الجمعية المصرية للكمبيوتر التعليمي

\%10.4 \%36.9 \%38.8 \%13.9

14 الأسئلة

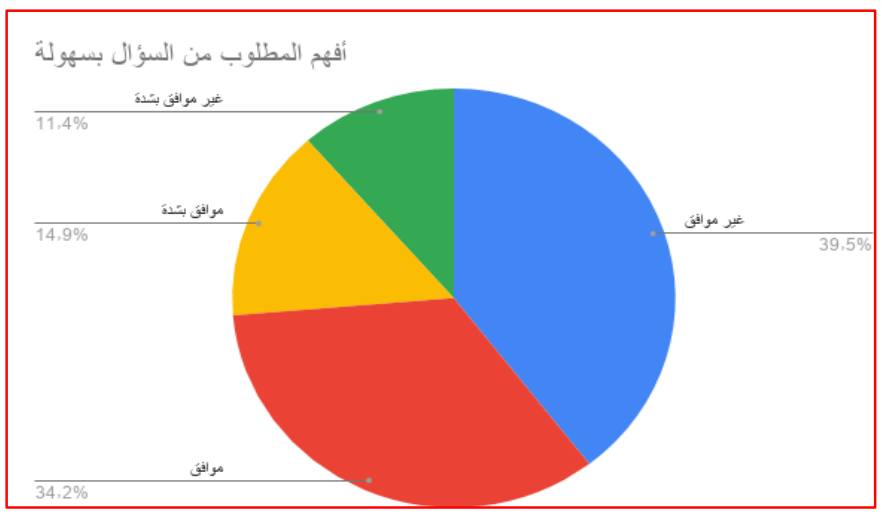

شكل(1) أفهم المطلوب من السؤال بسهولة

يلاحظ من الثكل (1) أن (49.1\%) من الطلاب يفهمون المطلوب في الأسئلة بسهولة، وأن (50.9\%) لا يتيسر لهم ذللك، و هي نسبة كبيرة تدل على صعوبة فهم الطلاب للسؤ ال، وقد يكون ذللك راجعًا إلى الطالب نفسه، أو راجعًا إلى صيغة السؤ ال، من حيث صعوبة صياغته أو ترتيب كلماته بطريقة تخالف قو اعد اللغة، أو طول السؤال الزائد.

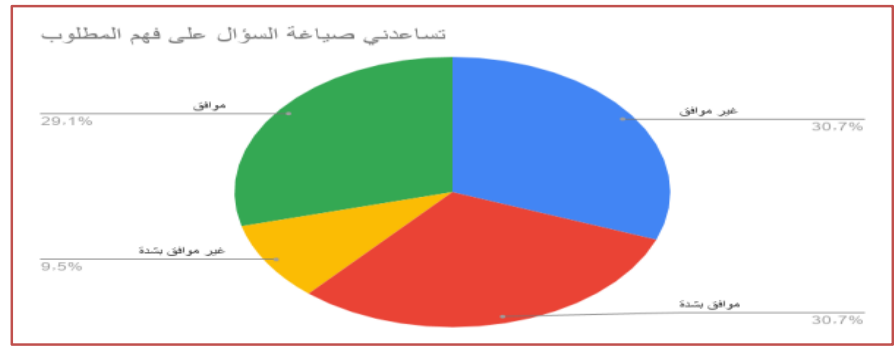

شكل(2) تساعدني صياغة السؤ ال على فهم المطلوب

ويلاحظ ــمن الشكل (2)- أن ما نسبته(59.8\%) تساعده صيغة السؤال على فهم المطلوب منه، و أن (40.2\%) منهم يفهون المطلوب من السؤ ال بغض النظر عن صيغته. وتدل نسبة المؤيدين(59.8\%) على أهمية العناية بصياغة الأسئلة بطريقة واضحة وأسلوب موجز، بل يُعَد ذلك من ضرور ات كتابة أسئلة الاختبار ات.

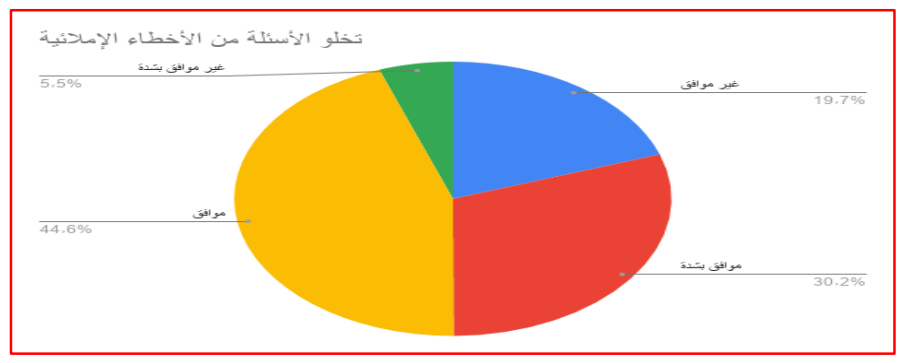


مجلة الجمعية المصرية للكمبيوتر التعليمي

شكل(3) تخلو الأسئلة من الأخطاء الإملائية

من الشكل(3) أقر(74.8\%) من طلاب الاستطلاع أن أسئلة الاختبارات خالية من الأخطاء الإملائية، وأن(25.2\%) منهم يجدون أخطاءً إملائية بورقة الأسئلة، وطبقًا لما تجمَّع لاى الباحث من أور اق الاختبار ات وما حو اه غالبها من أخطاء إملائية إلا في القليل النادر، فإن هؤلاء الطلاب الذين نفوا وقوع أخطاء إملائية في أوراق الأسئلة قد لا يعرفون الصواب من الخطأ في كتابة همزات الوصل و القطع، و التاء المربوطة و الهاء؛ لأن غالب الأخطاء الإملائية في هاتين القاعدتين. أو أنهم صادفوا أسئلة لأساتذة مجيدين للكتابة دون أخطاء. فقد وجدتُ أكثر الأخطاء الإملائية في اختبار ات كليات البنات، وفي التخصصات العلمية، مثل الكيمياء و الفيزياء و الرياضيات.

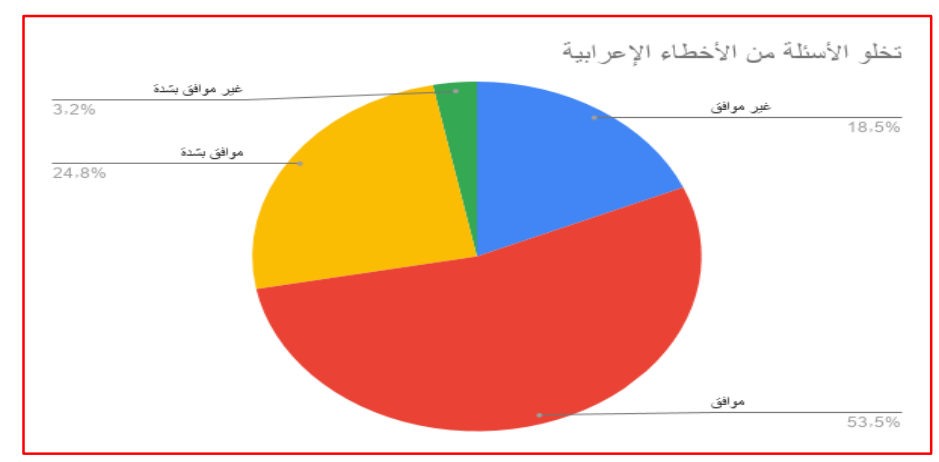

شكل(4) تخلو الأسئلة من الأخطاء الإعرابية

في الثنكل(4) يرى (78.3\%) من العينة خلو الاختبار ات من الأخطاء الإعرابية، ور أى(21.7\%) وجود أخطاء إعرابية في الاختبار ات. و الحق أن الاختبار ات حوت أخطاءً إعر ابية، لا يتفطن لها إلا المختصون بتدريس علوم اللغة، و الطلاب المتميزون النبهاء.

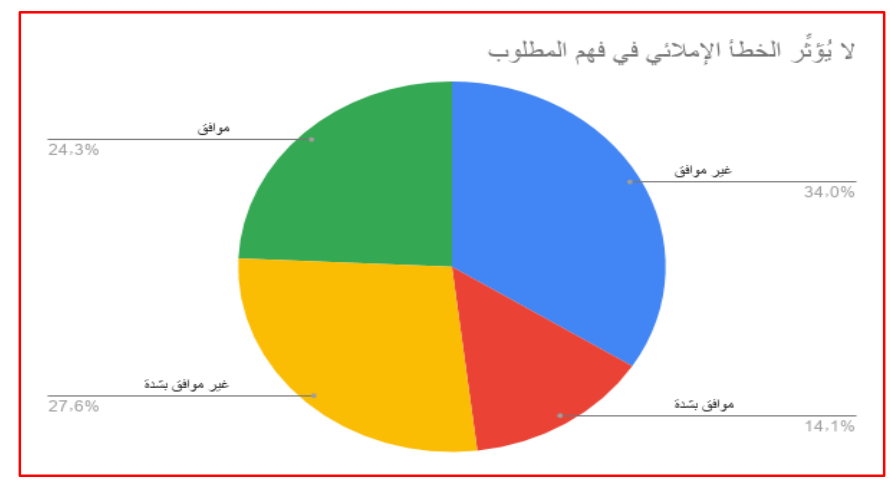

شكل(5) لا يؤثر الخطأ الإملائي في فهم المطلوب 
مجلة الجمعية المصرية للكمبيوتر التعليمي

ومن الثكل(5) يتضح أن نسبة من الطلاب بلغت(38.4\%) ترى إمكانية فهم الأسئلة مع وجود أخطاءٍ إملائية فيها، وأن ما نسبته(1.67\%) ترى أن الخطأ الإملائي يؤثر في فهم السؤال. و الحق أن الغالب هو تأثر المعنى بالخطأ الإملائي، على ما سنبيّن عند عرض الأخطاء وتحليلها، إن شاء الله.

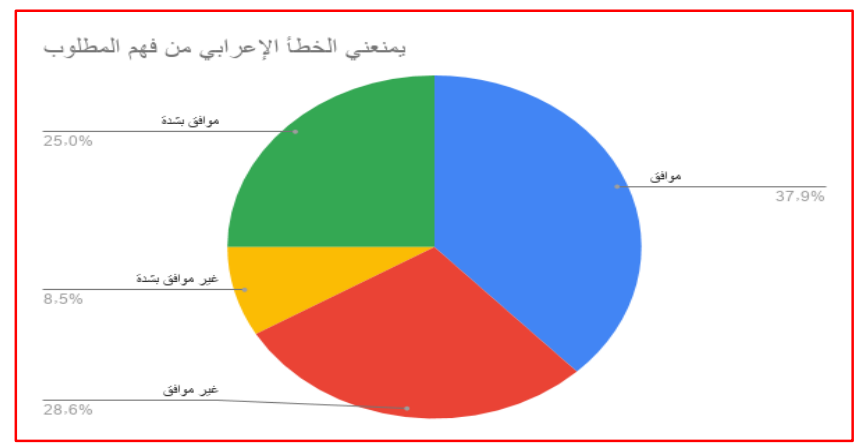

شكل(6) يمنعني الخطأ الإعر ابي من فهم المطلوب

وفي الثكل(6) يو افق(62.9\%) - من عينة الاستطلاع- على أن الخطأ الإعر ابي يمنعهم من فهم السؤال، أما ما نسبته(37.1\%) فترى أن أخطاء الإعراب لا تمنعهم من فهم المطلوب في السؤال، و الحق أن الخطأ الإعرابي له نأثثر في المعنى لأنه يغير من تركيب الجملة فيتغير المعنى.

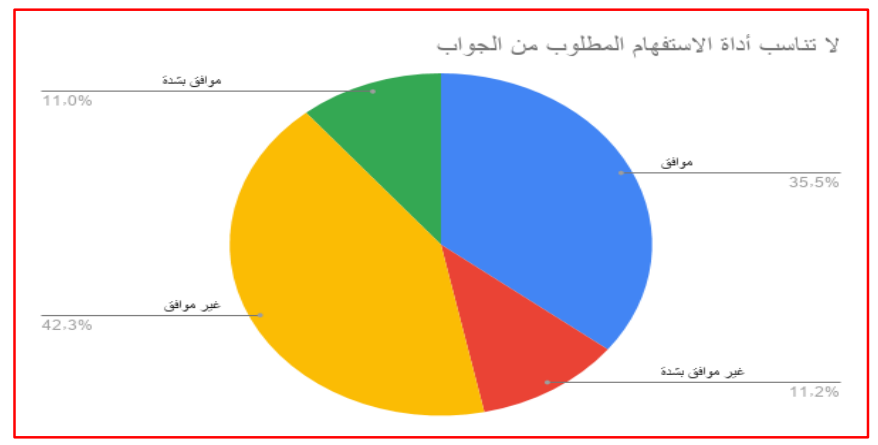

شكل(7) لا تناسب أداة الاستفهام المطلوب من الجواب

من الثكل (7) يرى(46.5\%) من العينة أن أداة الاستفهام لا تناسب المطلوب، أما ما نسبته (53.5\%) فترى أن أداة الاستفهام مناسبة للسؤال. ومن خلال استقر اء أسئلة الاختبار ات تبين أن أدوات الاستفهام المستخدمة مناسبة تمامًا للمطلوب، كما سنعرض لاحقًا، إن شاء الله. 
مجلة الجمعية المصرية للكمبيوتز التعليمي

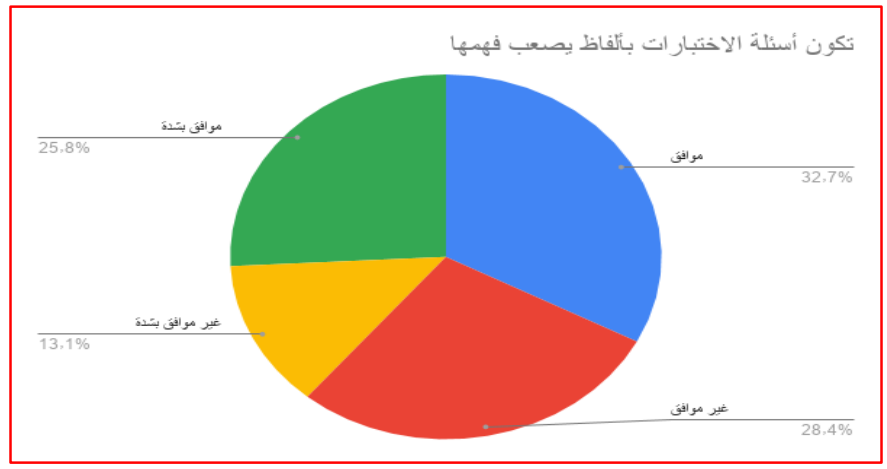

شكل(8) تكون أسئلة الاختبار ات بألفاظ يصعب فهمها

في الثكل(8) يرى (58.5\%) من العينة أن ألفاظ الأسئلة يصعب فهها، على حين يرى(41.5\%) منهم سهولة ألفاظ الأسئلة، ومن خلال فحص الاختبار ات تبين أن بعض كلمات الأسئلة كانت تحتاج إلى ضبط ليتمكن الطالب من قراعتها وفهمها، كما حوت الأسئلة عبار اتٍ ومصطلحاتٍ من المفترض أن يكون الطالب عارفًا لها، من خلال در استه للمقرر.

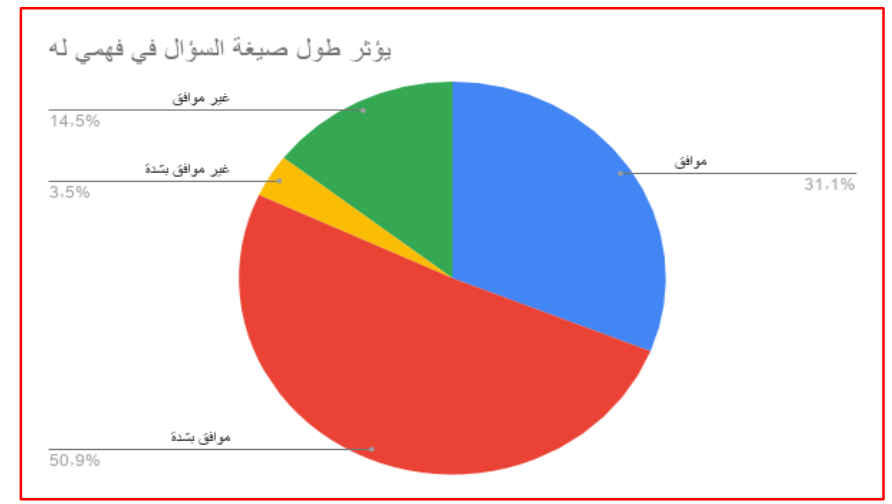

شكل(9) يؤثر طول صيغة السؤال في فهمي لله

في الثكل(9) برى(82\%) من العينة أن السؤال إذا طال فإنه بيؤثر في فهمه المطلوب في السؤال، على حين يرى(18\%) أن طول السؤال لا يؤثر في ذلك. ويبدو أن هؤلاء الذين لايرون لطول السؤال تأثثرًا اـ من الطلاب الفائقين المتميزين.

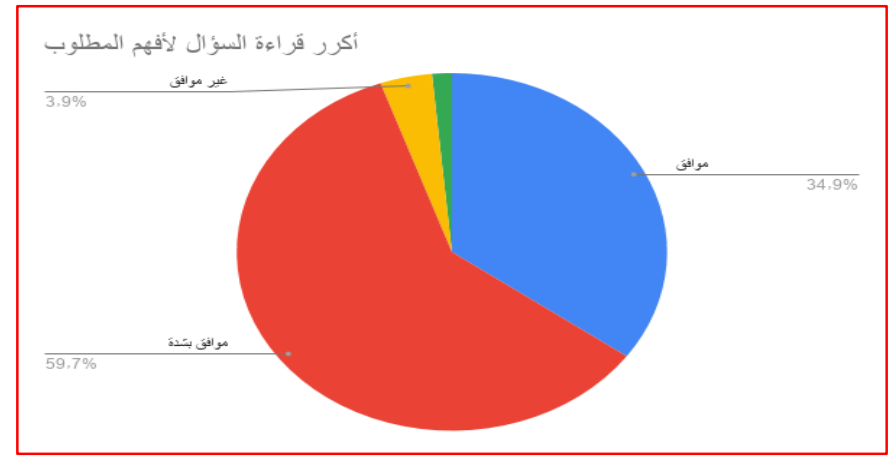

$=306=$

المجلد الثامن ـ العدد الثاني ـ مسلسل العدد (16) ـ ديسمبر 2020 
مجلة الجمعية المصرية للكمبيوتر التعليمي

$$
\text { شكل(10) أكرر قراءة السؤال لأفهم المطلوب }
$$

في الشكل(10) يكرر(94.6\%) من العينة قراءة الأسئلة قبل الإجابة عليها، وهذا هو الأحوط والأسلم للطالب؛ حتى يجيب إجابة صحيحة كما المطلوب، أو أن الأسئلة تطلب إجابات عن موضو عات صعبة الفهم على الطلاب، مما يتطلب منهم التدقيق في السؤال، أو أن الأسئلة صِيغَت بكلمات فيها صعوبة فتحتاج إلى تكرار قراءتها. على حين يرى(1.4\%) أنهم لا يحتاجون إلى تكر ار قر اءة الأسئلة.

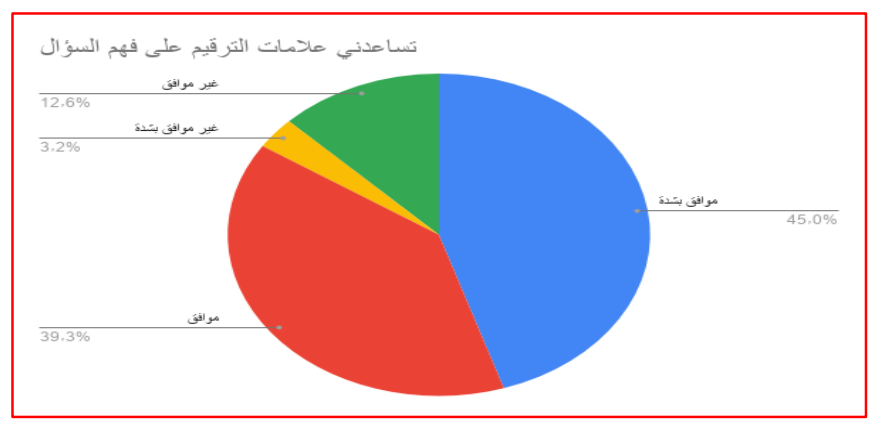

شكل(11) تساعدني علامات الترقيم على فهم السؤال

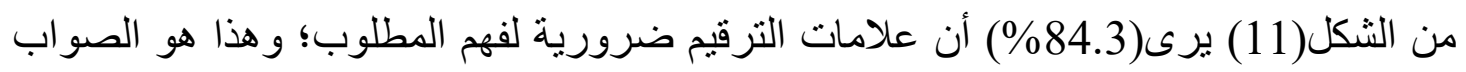
لأن تلك العلامات وُضعت لتمبيز الكلام بعضه من بعض، وقد وجدت تهاونًا في كتابة علامات الترقيم، في كثير من الاختبار ات. على حين يرى(15.7\%) أن علامات الترقيم لا نؤثر في فههم للسؤال.

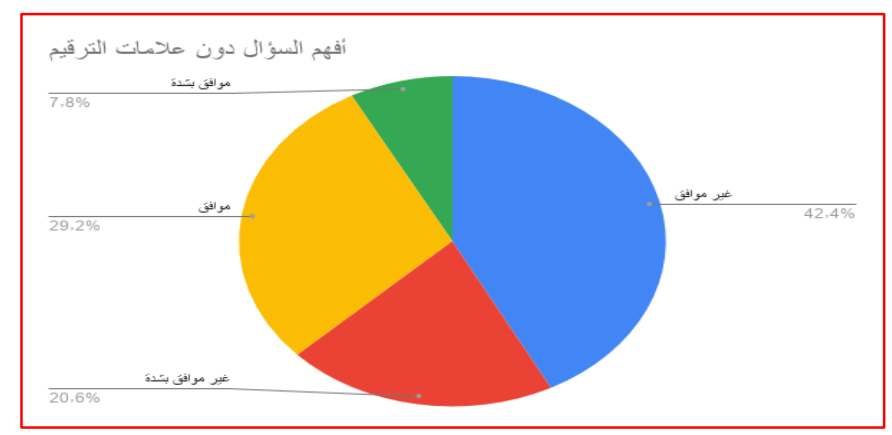

شكل(12) أفهم السؤال دون علامات الترقيم

في الثكل(12) يرى ما نسبته(37\%) من العينة أنهم يفهمون السؤال ولو لم يحتوِ على علامات ترقيم، هذه النسبة أكثر من ضعف مثيلتها في استطلاع السؤال رقم(12)، على الرغم من أن العبارتين منتابهنان. ويرى(63\%) أنهم لا يفهمون السؤ ال من دون علامات الترقيم. $=\mathbf{3 0 7}=$ 
مجلة الجمعية المصرية للكمبيوتر التعليمي

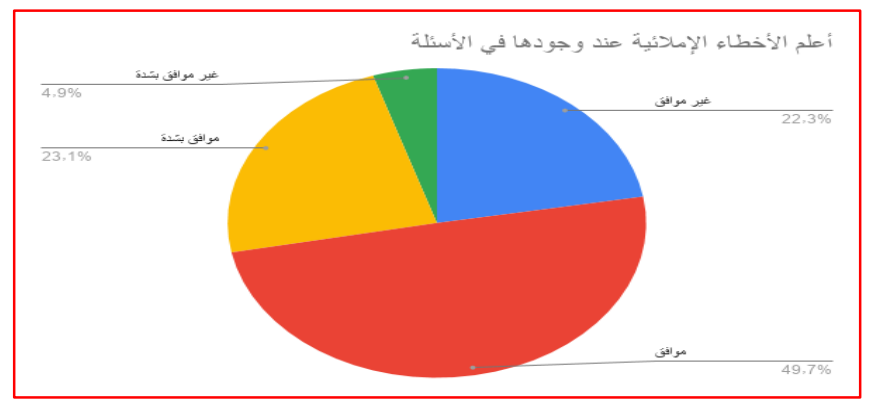

شكل(13) أعلم الأخطاء الإملائية عند وجودها في الأسئلة

وكما في الثكل(13) يرى(72\%) من العِّنة أنهم يعلمون الأخطاء الإملائية حال وجودها في السؤال، ويرى(28\%) أنهم لا بعلمون تلاك الأخطاء الإملائية.

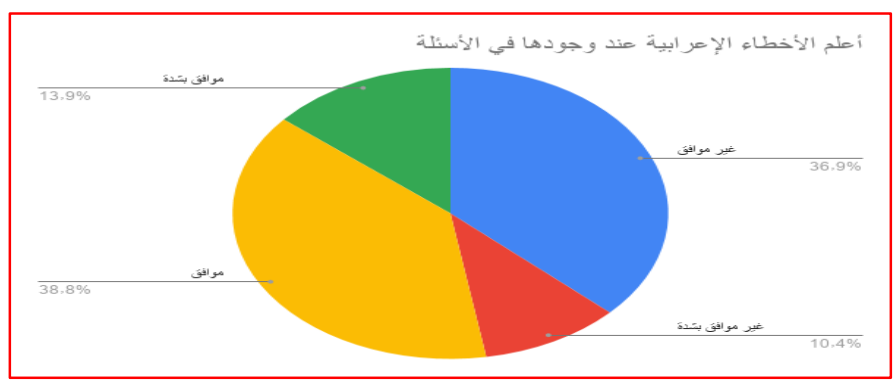

شكل(14) أعلم الأخطاء الإعر ابية عند وجودها في الأسئلة

ويتضح من الثكل(14) أن(52.7\%) من الطلاب يعلمون الأخطاء الإعر ابية إذاوقعت في الأسئلة، على حين يرى(47.3\%) أنهم لا بعلمونها، ورذه النسبة تتوافق إلى حدٍّ ما مع النسبة التي في

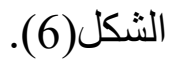

تلكم هي نسب استطلاع آر اء الطلاب في صياغة أسئلة الاختبار ات، وتعليق الباحث عليها. اللدراسات السابقة:

تعددت الدراسات التي تعالج قضية الأخطاء الثائعة عند العامّة والخاصّة، منذ القرن الثاني الهجري وحتى الآن، فهي من الكثرة والتنوع بمكان، ومن ذللك: (ما تلحن به العامة) للكسائي(189 هـ)، نشره الميمني. و(لحن العوام) لأبي بكر بن حسن الزبيدي(379هـ) بتحقيق رمضان عبدالتواب. و(تثقيف اللسان وتلقيح الجنان) لابن مكي الصقلي (501ه) بتحقيق عبدالعزيز مطر. و(درة الغوّاص في أوهام الخواصّ) لأبي القاسم الحريري (516ه). و(تقويم اللسان) لأبي الفرج عبدالرحمن بن الجوزي (597هـ) بتحقيق عبدالعزيز مطر. ونشر مؤخرًا 
(1987م) في مجلد واحد أربعة كتب في التصحيح اللغوي للخطابي ولابن برّي و لابن الحنبلي ولابن بالي، بتحقيق حاتم صالح الضامن. وفي العصر الحديث كتبت دراسات تناولت ضعف طلاب المدارس و الجامعات في اللغة، وطرق معالجتها، مثل: (مشكلة اللغة العربية: لماذا أخفقنا في تعليمها؟ وكيف نعلمها) لمحد أحمد عرفة (1945م). و و(اللغة العربية في التعليم العالي والبحث العلمي) لمازن المبارك (1973م). و (مقدمة في علم تعليم اللغة العربية) لنهاد الموسى (1984م). وكتاب (تطوير مناهج تعليم القو اعد النحوية وأساليب التعبير في مر احل التعليم العام في الوطن العربي)، إعداد: محمود أحمد السيد (ط1، المنظمة العربية للتربية والتقافة والعلوم/ تونس، 1987م). و (دليل بحوث تعليم اللغة العربية والدين الإسلامي في الوطن العربي: 1900م-1980م)، المنظمة العربية للتربية والثقافة والعلوم، إدارة التربية/ تونس، 1983م. ودراسة (ظاهرة الضعف العام في استعمال اللغة العربية) (جامعة الإمام محمد بن سعود الإسلامية/ الرياض، 1992م). كما ظهرت دراسات تعالج الأخطاء الثائعة عند الكتاب و الإعلاميين و الصحفيين، مثل:(أخطاء اللغة العربية المعاصرة عند الكتاب والإذاعيين) لأحمد مختار عمر ، (مكتبة عالم الكتب، مصر، 1991م). و(معجم تصحيح لغة الإعلام العربي) لعبد الهادي أبو طالب. و (قل و لا تقل) لمصطفى جو اد (1980م). و(معجم الأخطاء الثائعة) لمحمد العدناني (1973م) و(العربية الصحيحة) لأحمد مختار عمر (1981م). و(كبوات اليراع) لأبي تراب الظاهري (1982م). و(تصحيحات لغوية)، لعبدالعزيز أحمد الثويرف (الدار العربية للكتاب/طر ابلس،1997م). و(إصلاحات في لغة الكتابة والأدب) لعبد القدوس الأنصاري (ط1، الكئ دار المنهل/ جدة، 2006م). (انظر: الثمسان، أبو أوس، مجابهة الضعف اللغوي: 1-4). ومن الدراسات التي تناولت الأخطاء اللغوية أيضًا:

1- در اسة محمد عبد الله صالح أبو الرب(2005م): (الأخطاء اللغوية مصادر هاواتجاهات تحليلها وتقويمها: دراسة في ضوء علم اللغة التطبيقي)، وقد تناولت قضية الأخطاء بجانبيها النظري و التطبيقي، وجاءت في ثلاثة فصول، تناول الفصل الأول أهمية در اسة الأخطاء و المصطلحات المتعلقة بالأخطاء، و أنو اع الأخطاء اللغوية، وطبيعة در اسة الأخطاء، من حيث كونها وصفية أو معيارية، وحددت مقاييس الصو اب و الخطأ اللغويين، ومر احل در اسة الخطأ اللغوي، وآلية تقويم 
مجلة الجمعية المصرية للكمبيوتر التعليمي

الأخطاء اللغوية وتصحيحها. وتتاول الفصل الثاني اتجاهات تحليل الأخطاء، وهي الاتجاه التقليدي و الاتجاه التقابلي والاتجاه التكاملي، وقد ركزت الدراسة النظرية في الفصلين الأول والثاني على ولى التهاهي متعلمي اللغة الأم أو اللغة الثانية. أما الفصل الثالث فهو الجانب التطبيقي من الدر اسة حيث أوضح عمليًّا الأصول النظرية في در اسة الأخطاء اللغوية لدى متعلمي العربية الناطقين بغير ها في جامعة اليرموك، في ضوء علم اللغة التطبيقي. 2- دراسة عبد المنعم الجاسم(2019م): "الأخطاء الإملائية في اختبارات المستوى المتوستط الأوسط: دراسة تحليلية تقويمية فى المعهد العالي للّفات بجامعة دمثق"، وقد هدفت هذه الدر اسة إلى رصد الأخطاء الإملائية لدى الطلاب الأجانب الدارسين للغة العربية ـلغنةً ثانيةًَ في المعهد العالي للغات في المستوى المتوسط الأوسط بدمثق- من خلال تحليل إجاباتهم في الاختبارات لمعرفة الأخطاء وتحديدها واقتر اح طرق حلها استنادًا إلى قو اعد الأخطاء الإملائية التي أجريت عليها الدراسة. وقد أجرى الباحث إحصاءً للأخطاء الإملائية والكتابية على وجه الخصوص الخص (الهمز ات بأنو اعها، التاء المبسوطة والتاء المربوطة، الألف المدودة والألف المقصورة)، وبيان الصح و الخطأ وقاعدة كل منها. ثم عدد الباحث في نتائج الدراسة أنواع الأخطاء الإملائية التي يقع فيها الطلاب الأجانب، ثم وضع اقتراحاتٍ للمعلين لزيادة تدريب الطلاب على الكتابة. و الدر استان السابقتان في جانبيهما التطبيقي تناولتا أخطاء متعلمي اللغة العربية الناطقين بغيرها. 3- دراسة حيدر محمد هناء حميد الشلاه(2012م): "الأخطاء الإملائية الشائعة لدى طلبة كلية الاراسات القر آنية في أداء همزتي الوصل والقطع". وتهدف هذه الدراسة إلى تعرّف الأخطاء التي يقع فيها طلاب الصف الثاني في كلية الدراسات القرآنية في قستَيْ علوم القرآن ولغته، في أداء همزتي الوصل و القطع عام(2011/2010م)، وقد أجرى الباحث اختبارين متباعدين ليتأكد من ثبات الاختبار، وبعد تحليل النتائج تبين أن الأخطاء في كتابة همزة الوصل في الأفعال هي الأعلى نسبة بين الطلاب تلاها الأخطاء في همزة الوصل في الأسماء ثم في الحروف ثم همزة القطع في الأسماء ثم في الأفعال ثم في الحروف. ثم أوصى المعلمين بالإكثار من تدريب الطلاب على كتابة الهمزة في أول الكلمة وسؤ الهم عنها دائمًا. 4-دراسة ماهر صبري، وصفاء سلطان، وأميرة الثافعي(2012م): "برنامج تدريبي مقترح لعلاج الأخطاء المنهجية واللفوية الثائعة في تقارير بحوث التربية العلمية المنشورة بالمملكة 
مجلة الجمعية المصرية للكمبيوتر التعليمي

العربية السعودية" وهي دراسة وصفية تحليلية لعينة ممثلة لبحوث التربية العلمية ودر اساتها المنشورة في المملكة العربية السعودية، في الفترة من(2001-2010م) وتحديد الأخطاء المنهجية و اللغوية الثائعة في تقارير تلك البحوث، مثل الأخطاء النحوية والصرفية، والأخطاء الأسلوبية و التركيبية، و الأخطاء الإملائية، ووضع برنامج تدريبي مقترح للباحثين في مجال التربية العلمية في المملكة العربية السعودية لعلاج هذه الأخطاء وتلافيها مستقبلً، مدة البرنامج(30) ساعة، خلال (5) أيام، كل يوم جلستان، أربعة أيام للتدريب على عمل منهجية البحوث التربوية بدءًا من كتابة العنو ان حتى صياغة النتائج و التوصيات، ويوم و احد(جلستان) للتدريب على تجنب الأخطاء اللغوية. وقد تناولت الدراسة أخطاء لغوية كثيرة، لكنها لم تراع قرار ات مجمع اللغة العربية في الألفاظ و الأساليب و التر اكيب.

5-دراسة صفاء عبد العزيز سلطان(2009م): "الأخطاء اللغوية الشائعة في البحوث التربوية المنشورة تشخيصها ومقترحات علاجها" وقد رصدت الأخطاء النحوية والصرفية والتركيبية و الأسلوبية و الإملائية وأخطاء علامات الترقيم، في البحوث التربوية في عدد من المجلات العلمية المحكمة في جمهورية مصر العربية، وهي: مجلة دراسات في المناهج وطرق التدريس، ومجلة القر اعة و المعر فة، ومجلة التربية العلمية، ومجلة در اسات عربية في التربية و علم النفس، في الفترة من (2001-2010م). لكن هذه الدر اسة لم تر اع قرار ات مجمع اللغة العربية بالقاهرة في الألفاظ و الأساليب و التر اكيب.

6-دراسة سليمان يوسف خاطر(1429هـ): "الأخطاء اللغوية في صياغة الاختبارات النهائية أسبابها وأنماطها وعلاجها: دراسة وصفية تحليلية تقويمية"، وكانت عينة تلك الدراسة الاختبار ات النهائية خلال خمسة فصول دراسية متتالية، بداية من الفصل الدراسي الأول للعام الجامعي(1425-1426هـ)، حتى الفصل الدر اسي الأول للعام الجامعي (1427-1428هـ)، شملت جميع التخصصات التي ثُدََّس باللغة العربية، في الأقسام العلمية بكلية المعلمين بحائل، وهي الدر اسات القر آنية و الدر اسات الإسلامية و اللغة العربية و التربية و علم النفس و الرياضيات و العلوم و الحاسب الآلي و التربية الفنية وتقنيات التعليم والتربية الرياضية و البدنية. وقد اتبع الباحث المنهج الوصفي التحليلي، كما جمع الأخطاء في التعبير والأسلوب و الصرف و النحو و الدلالة والإملاء. 
مجلة الجمعية المصرية للكمبيوتر التعليمي

فجاءت دراسته مستو عبة لكثير من أخطاء أسئلة الاختبار ات في كلية المعلمين بحائل، وكان من نتيجة در استه:

1-كثرة الأخطاء بأسئلة الاختبار ات، فقد أصبحت ظاهرة شائعة.

2- تنوع تللك الأخطاء، في الأصوات وفي الأسلوب و الإملاء و الصرف والنحو.

3- الوقوع في تلك الأخطاء سببه عدم الاهنمام بصياغة الأسئلة.

و اقترحت الدر اسة ما يأتي:

1-إقامة دور ات تدريبية تذكيرية لأعضاء هيئة التدريس.

2-تبادل أور اق الأسئلة بين الأساتذة بعد انتهاء الاختبار ات، لإبداء الملاحظات.

3-تشكيل لجنة بكل قسم لمر اجعة أسئلة الاختبار ات قبل طباعتها.

ويتضح أن دراستنا اختلفت حدودها الزمانية و المكانية وعينتها، وطريقة التحليل عن الدر اسة السابقة؛ فإن دراستنا شملت سبع كليات، ودراسة سليمان خاطر لكلية واحدة هي كلية المعلمين في حائل. كما أن الحدود الزمانية لدراسة سليمان خاطر من عام(1425-1428هـ)، خلال خمسة فصول دراسية، للاختبار ات النهائية الورقية فقط، أما دراستنا فمن عام(14291441هـ) أي (13) عاما جامعيًّا، خلال (26) فصلًّ دراسيَّا، شملت الاختبار ات النهائية و الثهرية، و الورقية والإلكترونية. و اتفقت الدر استان في المنهج، فدر استناوصفية تحليلية معيارية، ودر اسة سليمان خاطر وصفية تحليلية تقويمية، إلا أن در استتا تحلل أخطاء الاختبار ات في ضوء علم اللغة التطبيقي، وفي ضوء قرارات مجمع اللغة العربية بالقاهرة، الذي أجاز استخدام ما عده بعض اللغويين أخطاء- ومنهم صاحب الدراسة المذكورة- وقد ذكرنا هذه الأخطاء المجازة من المجمع اللغوي في المبحث الثالث. كما أن در استنا استطلعت آراء عدد كبير من الطلاب في أسئلة الاختبار ات، من حيث صعوبة عبار ات الأسئلة، وسرعة فهمه للأسئلة ومعرفة المطلوب في السؤ ال من خلال كلمات السؤال و أسلوبه. فقد طرح الباحث أربعة عشر سؤالًا على طلاب جامعة القصيم، من خلال موقع (جو جل مستندات)، مستبينًا رأيهم في الاختبار ات، وقد استجاب عدد منهم بلغ (1083) طالبٍ، من شنَّى كليات الجامعة، حيث نُشِر رابطُ الاستبانة لهم- عن طريق مستشار 
مجلة الجمعية المصرية للكمبيوتز التعليمي

عمادة التعليم الإلكتروني بجامعة القصيم (أ.د. محمد جابر خلف الله)- في المجمو عات الطلابية في برنامج التراسل(و اتساب)، مما أدى إلى استجابة عدد كبير من الطلاب، من المستويات المختلفة، و التخصصات الأدبية و العلمية.

\section{المبحث الأول}

\section{الأخطاء اللغوية في أسئلة الاختبارات الأسباب الدافعة}

مما لا شــك فيه أنتا نخطئ عند تعلمنا للغة و عند اسـتعمالنا إياها، و إن وقوع متعلم اللغة ـ .

أيَّا كان - في الأخطاء، هو أســاس تعلمه، فالأخطاء اللغوية جزء لا يتجز أ من تعلم اللغة؛ حتى يتمكن المعلم من توجيهه إلى الصـــواب؛ فيتجنب الذطأ مرة ثانية؛ يقول دوجلاس براون: "إن

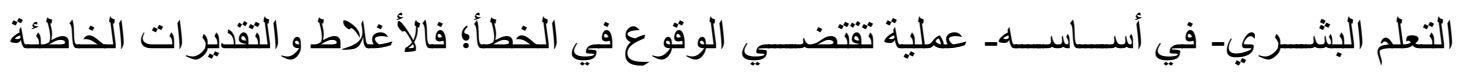
و الحســابات و الافتر اضــات غير الصــحيحة، تشــكل جانبا مهما من جو انب تعلم أية مهارة، أو

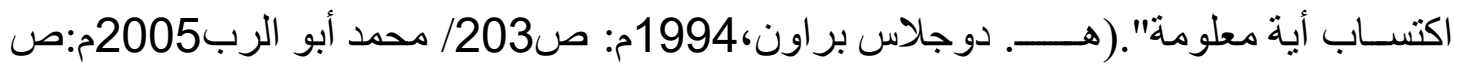

ويتعين على المتعلمين أن يدركوا أخطاءهم حتى لا يسيطر عليهم إحساس بالخوف و الفشل عند تعلمهم للغة، فعندما يدركون أخطاءهم تللك، فإن ذلك يعد مؤشر ا على اهتمامهم بتحسين مستو اهم وبلوغ مستوى متقدم، فتزيد الدافعية عندهم إلى تصحيحها و عدم إهمالها، فيجنبون أنفسهم بذلك العجز اللغوي. (هكتر هامرلي1994م: ص122، نقلا عن: منال اليافعي2016م: ص88).

فيُعد الخطأ ظاهرة بارزة في المنظومة التعليمية، في الأداء الفعلي للكلام سواء أكان هذا الأداء منطوقا أم مكتوبًا. و على ذللك تأكد وجوب الاهتداء إلى الأسباب الكامنة ور اء تللك الأخطاء؛ بقصد نوصيفها وضبطها وحصر مجالها الإجرائي(منال اليافعي2016م: ص1). و هنالك اتجاهات عديدة حملت على عاتقها أمر تحليل الأخطاء اللغوية ومعالجتها منها: $=313=$ 
مجلة الجمعية المصرية للكبيوتر التعليمي

الاتجاه التقلياي الذي عرفته الثقافة العربية في كتب لحن العامة والخاصة، عن طريق علماء اللغة في القرون الثلاثة الأولى، الذين بذلو ا جهودا كبيرة لمقاومة ظاهرة اللحن في اللغة. والاتجاه الحديث الذي تبناه اللغويون الغربيون، فقد عالجوا الأخطاء في إطار علم اللغة التطبيقي، حيث تمكنوا من بلورة تصور ات جديدة مكنت من إيجاد حلول عملية لبعض المشكلات المتصلة بتعليم اللغة، ومن ضمنها ارتكاب أبناء اللغة الأولى الأخطاء اللغوية نفسها، ويظهر ذللك من خلال نتائج الاتجاهات التي عرضها علم اللغة التطبيقي، بدءًا من الاتجاه التقابلي مرورا باتجاه تحليل الأخطاء وصولا إلى الاتجاه التكاملي الذي يجمع بين الاتجاهين الأخيرين. (منال اليافعي 2016م: المقدمة). وحقيقة فإن الاتجاه التقابلي في تحليل الأخطاء ظهر عند تعليم اللخات الأجنبية؛ لتُقابَل اللغة الأصـلية للمتعلم باللغة الأجنبية المقصــود تعلمها؛ لأن المتعلم بنقل خبرته بلغته الأولى عند در اسة اللغة الثانية فيحدث الخطأ. فكان هذا الاتجاه التقابلي؛ و صولًا إلى طريقة التعليم الصحيحة التي ثُقَرِّب إلي المتعلم فهم اللغة الثانية و اسـتيعابها وتجنب الخطأ في اسـتعمال أسـاليبها وقو اعدها (محمود إسماعيل صيني، و إسحق محمد الأمين 1982م: المقدمة).

و عالجت البحوث التقابلية أيضا أخطاء متعلمي اللغة الأولى في مراحل نموهم، أطفالا، وفي مراحلهم الدر اسية؛ فتحدث الأخطاء نتيجة للازدواج اللغوي بين اللهجة الأم التي ينشأ عليها الطفل و اللغة الفصحى المنشودة؛ بسبب التداخل بين النظام اللغوي للهجة و النظام اللغوي للفصحى، حيث كانت تتأثر باللهجة، فقامت تللك البحوث التقابلية بدر اسة الفروق بين اللهجة الأم من جانب و اللغة الفصحى المنشودة من جانب آخر؛ لأجل التنبؤ بتلك الأخطاء، ولكن هذه البحوث التقابلية فسرت جانبًا من الأخطاء، ولم تفسر الأخطاء المختلفة، فجاءت نظرية تحليل الأخطاء التي تبناها اللغوي الأمريكي، الفرنسي الأصل(كوردر Corder) وآخرون، و عارضوا بها نظرية التحليل التقابلي، وقالو ا: إن سبب الأخطاء ليس التدخل من اللغة الأم فحسب، بل هنالك أسباب أخرى داخل اللغة الهدف، و هذه الأسباب تطورية، مثل: أسلوب التعليم، والدراسة، والتعود، و النمو اللغوي، وطبيعة اللغة المدروسة،، والتعميم، والسهولة، والتجنب، والافتر اض الخاطئ، و غير ها. كل هذه العو امل لها أثرها فيما يو اجه الدارسون من مشكلات، بغض النظر عن أوجه التشابه والاختلاف بين لغة الدارسين، و اللغة الثانية التي يتعلمونها. كما يرى أصحاب نظرية تحليل الأخطاء: أنه عن طريق تحليل الأخطاء- فقطـ نستطيع أن نتعرف إلى حقيقة المشكلات التي تو اجه الدارسين أثناء 
مجلة الجمعية المصرية للكمبيوتر التعليمي

تعلمهم للغة. ومن نسبة ورود الخطأ نستطيع أن نتعرف مدى صعوبة المشكلات أو سهولتها، وبناء على هذا، فلا حاجة لنا إلى التحليل التقابلي. (محمود صيني، وإسحق الأمين1982م: المقدمة؛ محمود فهمي حجازي1992م: ص81؛ عبده الر اجي41995م: صاي؛ جاسم علي جاسم2009م: ص153؛؛ جلايلي سمية2017م: ص132).

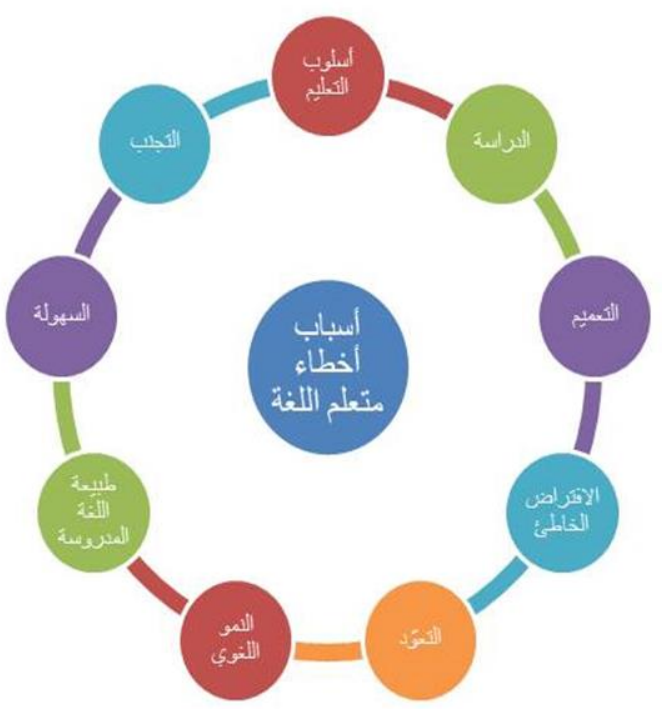

شكل رقم (15) أسباب أخطاء منعلم اللغة

وفي إطار التقدم في علمي اللغة والنفس أصبح الوصول بمتعلم اللغة إلى الأهداف السلوكية المنشودة موضع الاهتمام، وفي الوقت نفسه اهتم علماء اللغة بتصنيف الأخطاء وتفسير ها بالمعايير اللغوية، وتحليلها ومعرفة الأخطاء المشتركة التي يقع فيها كل الدارسين، لبيان أسبابها ومر اعاتها عند تدريس اللغة، وتحول الاهتمام من طريقة التدريس إلى دراسة نواتج التعلم. (محمود فهمي

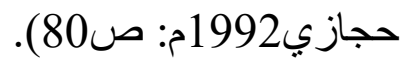


مجلة الجمعية المصرية للكمبيوتر التعليمي

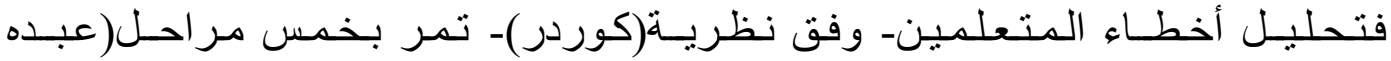
الرجحي،1995م:ص20/ يوكي ســور يـادار ما2015م: ص272/ جاســـم علي جاســـ2009م:

$$
\text { ص160) }
$$

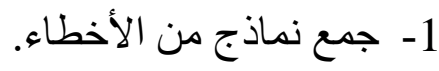

2- تحديد الأخطاء.

3- 3 وصف الأخطاء.

4- شرح الأخطاء وتفسير ها.

5- تصويب الأخطساء و علاجها.

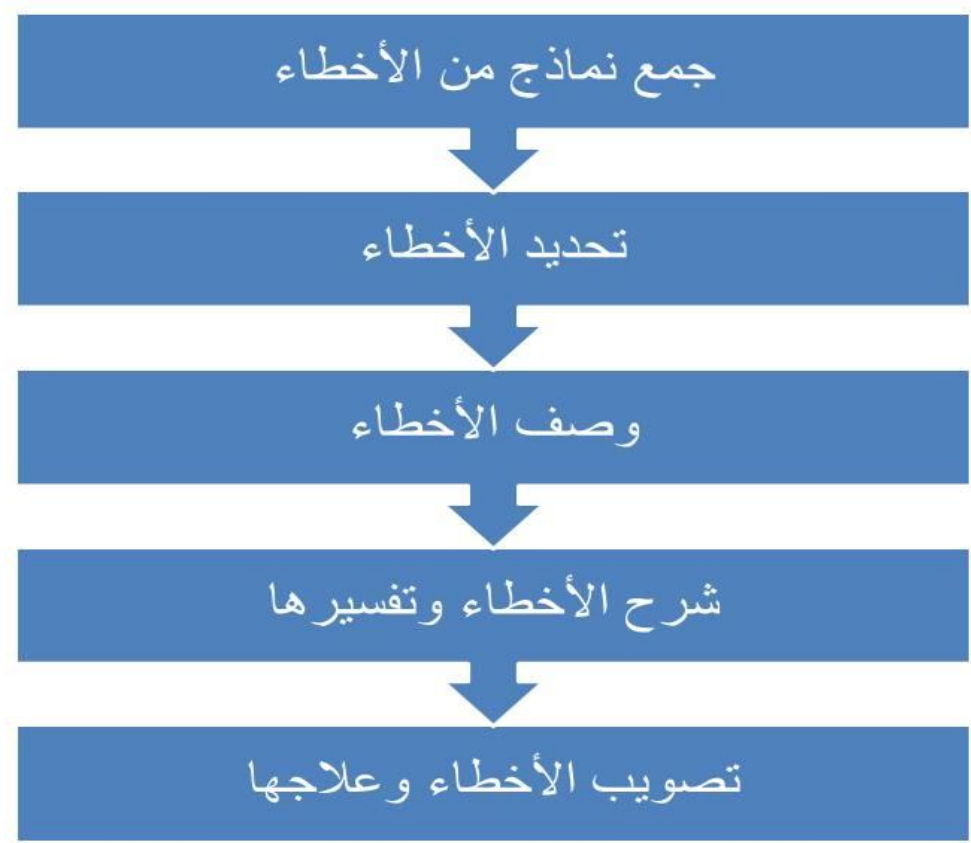

شكل(16) مر احل تحليل الأخطاء وفق نظرية كوردر

ويطر ح الباحث هنا بعض الأسئلة:

- - هل الأســـباب التي ينتج عنها أخطاء متعلم اللغة الثانية هي نفســـها التي بنتج عنها

أخطاء متعلم اللغة الأولى؟

- وهل أخطاء هؤلاء هي نفس أخطاء أولئك؟

$$
=316=
$$

المجلد الثامن - العدد الثاني - مسلسل العدد (16) - ديسمبر 2020 
لا شـك أن أخطاء صـاحب اللغة تختلف عن أخطاء الأجنبي، فأخطاء صـاحب اللغة ترجع في العادة لأســباب فيزيقية (كالإر هاق و المرض)، أو أســباب نفســية (كالتوتر و الثــــ)، و هذه الأخطاء مردهاز لات اللسـان (أو القلم) في الحذف و النقل والتكرار وتغيير خطة الكلام، بأن نبدأ بتركيب ثم ذعدل عنه إلى تركيب آخر. أما أخطاء الأجنبي فترجع إلى عوامل في التعلم أو إلى نقص في المعرفة بـالنظسام اللغوي الذي يتعلمه (عبده الراجحي595؛ محمود فهمي حجازي1992م:ص18).

و الحقيقة أن كتب اللسانيات رغم حديثها عن اختلاف أسباب أخطاء متعلم اللغة الأولى عن أسباب أخطاء متعلم اللغة الثانية، فإنها عند تحليل الأخطاء تجد مؤلفيها يجنحون إلى تفصيل الأسباب الخاصة بمتعلم اللغة الثانية فقط؛ لأن عندهم من القناعات أن ما يحتاجه متعلم اللغة الأولى نفس ما يحتاجه متعلم اللغة الثانية، من عو امل نفسية واستر اتيجيات تدريسية ومهار ات لغوية (انظر مثلا: عبده الراجدي51995م:ص36-56؛ هـ.دوجلاس براون،1994م: الفصول من الخامس إلى السابع ص103، و127؛ رشدي طعيمة، 2004م: ص105؛ محمود صيني و إسحاق الأمين،

1982م: ص1192) (19) (19)

كما أن أخطاء متعلم اللغة الثانية تختلف عن أخطاء متعلم اللغة الأولى (الأم)، فمتعم اللغة الثانية أخطاؤه تشبه أخطاء الطفل الذي يتكلم بلغته الأولى، وتتمثل تلك الأخطاء في استخدام صيغة الجمع و المفرد، أو تذكير المؤنث وتأنيث المذكر، وفي تغيير صفات الأصو ات المفخمة والثديدة، و المجهورة، مما يحولها إلى نظير اتها المرققة و المستفلة و الرخوة و المهموسة، أو في القلب المكاني للأصو ات.

كما أن أخطاء متعلم اللغة الثانية تتمثل في اضطر اب دلالة الألفاظ عنده، و الخطأ في تركيب الجملة باستخدام حرف الجر غير المناسب، والخطأ في التعريف والتنكير، وفي الإضافة وفي الصفة، إضافة إلى الأخطاء الصرفية الإملائية والإعرابية وغير ذلك.(معهد تعليم اللغة العربية لغير الناطقين بها بجامعة أم القرى(د.ت): ص12). 
مجلة الجمعية المصرية للكمبيوتر التعليمي

أما صاحب اللغة الأولى فتتمنل أخطاؤه في الأخطاء الإملائية والنحوية والصرفية و التركيبية، ولكن بدرجة أقل كثيرا من مثيلاتها عند متعلمي اللغة الثانية. فالأخطاء الصوتية تكاد تكون غير موجودة عند متعلمي اللغة الأولى، الخالين من أمراض الكلام، فصاحب اللغة ـالذي أنهى مر احل تعلمهـ نادرًا ما يخطئ في استخدام المفرد مكان الجمع أو العكس، أو يُذَكِرْر المؤنث أو العكس، أو يُغَيِر تركيب الجملة تغيير ا فاحشًا. فكل هذا لا نجده عند صساحب اللغة الأولى.

ومن نتائج اللسانيات التطبيقية، وخبرة الباحث في تعلم اللغة وتعليمها_لغةً أولىـ أجد أن الأسباب الدافعة لوقوع صاحب اللغة الأم في الخطأ اللغوي منها ما يتعلق بالمتعلم نفسه، ومنها ما يتعلق بالمقرر التعليمي، ومنها ما بتعلق بالمعلم، ومنها ما يتعلق ببيئة التدريس.

أولاً: الأسباب المتعلقة بمتعلم اللغة الأولىى:

1- ضعف مستو اه وضآلة حظه من الذكاء.

2- غيابه كثير ا عن المدرسة.

3- شرود ذهنه، لعجزه عن إرهاف سمعه وحصر ذهنه.

4- تردده وخوفه وارتباكه.

5- ضعف سمعه أو بصره.

6- 6 - 6ر عة نسيانه.

7- ضيق المتعلم بمقرر اللغة؛ لتقديمه له بطرق لا تناسبه.

8- الخوف الدائم من الخطأ أو الفشل.

9- ضعف ثقافة المتعلم، و ابتعاده عن القر اعة الحرة.

10- وجود عيوب كلامية عند المتعلم كاللثغة أو الحبسة. (عبد العزيز إبراهيم العصيلي3006م: ص303الفصل الثامن):

ثانيًا: الأسباب الخاصة بالمقرر التعليمي:

1- صعوبة المقرر التعليمي؛ بألا يناسب سن المتعلم. 
مجلة الجمعية المصرية للكمبيوتر التعليمي

2- لا يتناسب الوقت المخصص مع المقرر، لطوله أو صعوبته.

3- قلة الأمثلة المبينة للقاعدة.

4- التدريبات لا تشمل كل أجز اء المقرر.

5- وجود أخطاء لغوية في الكتب التعليمية، مما يشوش على المتعلم.

ثالثًا: الأسباب المتعلقة بالمعلم نفسه:

1- - ضعف تمييز الأصو ات.

2- انخفاض صوته أثناء الثرح.

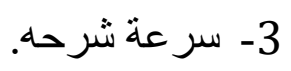

4- إهماله الطلاب الضعفاء وبطيئي الفهم.

5- قلة تبيينه للأصوات المتقاربة.

6- إثباعه الز ائد للحركات فينتج عنها المدود.

7- يكون جاهلا بأصول الوقف، أثناء القر اءة والإملاء.

8- ضعف استر اتيجيات التدريس.(عبد العليم إير اهيم، 1975م: ص22، 23).

\section{رابعًا: الأسباب المتعلقة بيئة التدريس:}

1- - كثرة الطلاب داخل القاعة الدر اسية.

2- ل الايتوفر المقعد المريح.

3- حرارة الجو غير المناسبة.

4- الضوضاء الثنديدة.

5- الإضـاءة الضعيفة أو الثديدة داخل قاعة الدر اسة.

$$
\text { 6- ضعف التهوية. }
$$

7- نظافة القاعة الدر اسية.

8- ندرة الوسائل التعليمية.

9- ضعف خبرة معلمي المقرر ات الأخرى في استخدام اللغة.

$$
=319=
$$


مجلة الجمعية المصرية للكمبيوتر التعليمي

و لا شك أن و اضع أسئلة الاختبار ات أستاذ أكاديمي متميز عن أقر انه منذ طفولته؛ و أثناء در استه اللغوية. و الطلابـ في بلادنا العربية- يدرسون المقررات اللغوية ويتدربون على مهار اتها من المرجلة الأساسية في التعليم حتى نهاية المرحلة الثانوية، و أحيانا تمتد في المرحلة الجامعية؛ لأنها لغتهم الأم التي يجب عليهم إتقان مهار اتها، شأنهم في ذلك شأن الطلاب في الدول الأجنبية. وقد عايَشَ الطلابُـــ الذين صاروا أعضاء هيئة التدريس في الجامعةــ اللغةَ ومارسوها منذ المراحل الأولى من طفولاتهم، التي تمكنهم من اكتساب مهارات اللغة، وهي مهارة الاستماع، ومهارة الكلام، ومهارة القراعة، ومهارة الكتابة. فمهارة الاستماع و الكلام بدأ بتعلمهما في مرحلة الطفولة، مع محاكاته لمن حوله من المتكلمين(هـ. دوجلاس براونة 1994م: ص58)، ومهارة الكتابة يكتسبها في مراحل متقدمة، مع دراسة قواعد الإملاء، وقو اعد النحو وقو اعد الصرف المرتبطة بالإملاء. كما مارس الكتابة من خلال دروس الإملاء ودروس التعبير(الإنشاء). فلنا أن نستبعد أغلب الأسباب الخاصة بالمتعلم، لأن المتوقع تميز هم وتفوقهم الدر اسي، إلا ما كان من: 1- ضعف ثقافة المتعلم، وابتعاده عن القراءة الحرة. 2- نسيانه القو اعد اللغوية التي درسها. 3- إهمال الصياغة وقلة التدقيق و التحري عن الصوابـ ما دام المعنى مفهومًا، حسب رأيه. 4- الخوف من عرض الاختبار على أحد المختصين؛ حتى لا يفقد سريته.

\section{المبحث الثاني}

\section{المستويات اللغوية لأخطاء أسئلة الاختبارات الورقية والإلكترونية}

إن كون عينة تحليل الأخطاء هي أسئلة الاختبار ات لهو أقرب إلى الصدق في معرفة قدرة متعلم اللغة على الأداء الإنتاجي للغة؛ لأن كاتبها يكتبها و لا يدري أنها عينة للار اسة، و إنما يكتبها للطلاب في مجال الاتصال، وبالتالي فإنتاجه للأسئلة يعكس قدرته على تلقي اللغة وفهها ثم إنتاجها.(عبده الر اجحي1995م:ص25). وشملت العينة أنو اع الأسئلة كلها المقالية و الموضو عية، في الاختبار ات الورقية، أما الاختبار ات الإلكترونية فكان أغلبها أسئلة موضو عية، كأسئلة الصو اب 
و الخطأ، والاختيار من متعدد. والقليل منها كان من الأسئلة المقالية متمثلة في أسئلة الإجابات

القصيرة.

\section{الخطأ اللغوي والتغيز الالالىي:}

غالب الأخطاء يترتب عليه تغير دلالة الكلام؛ فلو جعل الكاتب هزة الوصل قطعًا، في مثل: (أكتُبْ)، فرسمها (أكتب) لتحولت من صيغة أمر المخاطَب إلى صيغة المضار ع للمتكلم الذي لُّي يُخبر عن نفسه أنه يكتب؛ أي تحولت الجملة من الطلب إلى الخبر.

- ولو كتب و اضع الأسئلة: (مما يتركب جزيء الماء؟) بألف في (مما) لتحولت (ما) من استفهامية إلى(موصولة)، وتغير معنى الجملة من الطلب إلى الخبر.

- ووضع الهاء بدل التاء في كلمة(معادلة) يحولها من كلمة مفردة إلى كلمتين (مُعادِله) وتغيرت الدلالة.

- و إذا لم نكتب ألفًا بعد الواو في مكانها الصحيح، فلن يستطيع القارئ أن يُفرق بين المفرد و المثنى

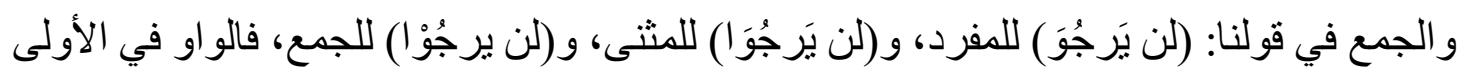
حرف من الفعل، و الفاعل ضمير مستتر(هو)، وفي الثانية كذللك، والألف ضمير المثنى فاعل، وفي الثالثة الو او ضمير الجمع في محل رفع فاعل، والألف بعدها حرف فارق بين الواو التي هي حرف وفي ولئ

$$
\text { والواو التي هي ضمبر(اسم). }
$$

- و إذا لم يلتزم الكاتب بعلامات الترقيم، فقد يلتبس على القارئ المعنى المر اد، فمثلا إذا قلنا:

$$
\text { - - - }
$$

فالأولى إخبار بصحة الإجابة، والثانية فرح أو تعجب من إصابة الإجابة الصحيحة، و الثالثة استقهام عن صحة الإجابة. فلا يمكن التفريق بين هذه المعاني دون الترقيم الصحيح. $=321=$ 
مجلة الجمعية المصرية للكمبيوتر التعليمي

-و إذا لم يضع الكاتب الكلام المنقول عن غيره بين علامني التتصبص (" ") لما علمنا كلامه من كلام غيره. و إذا كتبنا هذه الجملة: (لا تحزن من قول خالد إنك رجل فاضل!) دون كتابة فاصلة منقوطة بعد كلمة(خالد)، أودون كتابة نقطتين رأسيتين، لالتبس المعنى على القارى، وتعجب من حزن المخاطَب و(خالد) بمدحه؛ لأن الذي بُفهَم حينئذٍ أن مقولة (خالد) عن المخاطَب هي أنه رجل فاضل، ولكن الصواب أن الذي قال (لا تحزن من قول خالا)، هو نفسه الذي يقول: (إنك رجل فاضل). وقول خالد غير مذكور؛ لأنه معلوم للمتكلمَينِ؛ لذلك يجب وضع فاصلة منقوطة بعد كلمة

ومن خلال فحص أوراق الأسئلة فيما أُتيح للباحث من خلال ما توفر لديه من اختبار ات

كلية المجتمع ببريدة، وكلية العلوم والآداب في عنيزة، خلال العامين الجامعيين(1440/39هـ) و(1441/1440هـ)، و عددها اثناعشرة و مائة(112) اختبار ، إضافة إلى نحو سبعين و أربعمائة (470) اختبارٍ احتفظ بها الباحث من موقع (كويزات) الإلكتروني، الذي يرفع عليه طلاب الجامعات السعودية اختبار اتهم، ومنها اختبارات جامعة القصيم، بكلياتها المختلفة، على هذا https://koizat.com/category/\%d8\%ac\%d8\%a7\%d9\%85\%d8\%b9\%d8\%a9-): الر ابط:

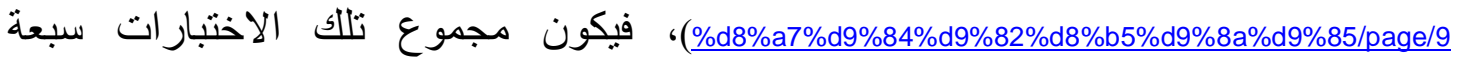
وثمانين وخمسمائة (587) منذ العام الجامعي(1429/28 هـ) وحتى نهاية الفصل الثاني من العام الجامعي(1441/40 هـ)، شملت الاختبار ات الورقية والإلكترونية المصممة على برنامج التعلم الإلكتروني المعتمد في جامعة القصيم (black board). و هي فترة زمنية تمتد على مدار ثلاثنة عثر(13) عامًا جامعيًّا، يتضح من خلالها نو عية الأخطاء اللغوية، وتطور ها، في اختبار ات جامعة القصبم.

و ونهج الباحث في تحليل أخطاء الاختبار ات هو الإشارة إلى الخطأ فقط مع تصويبه وبيان القاعدة الصحيحة، دون ذكر السؤال الذي سيق فيه، أو اسم المقرر الذي ورد فيه الخطا، إلا إذا تطلب الثرح ذللك؛ لزيادة الإيضاح. وكذلك لن يذكر الباحث اسم الكلية؛ لأن الهدف أن يهتدي القارئ إلى معرفة الخطأ وتجنبه لاحقًا، وليس إلى التشهير بكاتبه و لا بمكان عمله. 
كما أن الباحث أهمل الألفاظو الأساليب و التر اكيب التي أجاز استعمالها مجمع اللغة العربية بالقاهرة، مثل دخول (ال) على (غير). وإجازة الفصل بين المضاف و المضاف إليه بالمعطوف، مثل:(اكتبي عن مز اياو عيوب الحبس قصير المدة). و إجازة جمع (مدير ) على(مدر اء) بتو هم الميم أصلية. وإجازة إضافة الضمير(هو) أو(هي) بعد (ما ومن الاستفهاميتين). وإجازة سبق أداة الاستفهام بكلام، مثل:(الأمر بعد الحظر ماذا يفيد؟). وإجازة دخول الباء على الثيء المأخوذ في مِثل: (استبدلت السيارة بالار اجة). وإجازة إحلال حرف جر مكان آخر، مثل(أجب على) و(يؤثر على)؛ أما إحلال حرف جر مكان حرف آخر يؤدي إلى تغير دلالة الفعل؛ فهذا قد نوَّهنا إليه. فلنا في قرارات مجمع اللغة العربية سعة، وهي قرارات صادرة عن دراسة مستفيضة لكلام العرب و أقو ال العلماء. هذا وقد تنو عت المستويات اللغوية لتلك الأخطاء على النحو التالي:

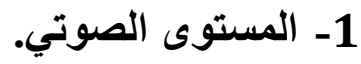

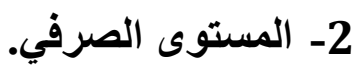

3- 1المستوى النحوي.

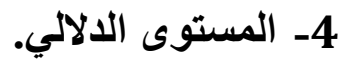

أولاً: المستوى الصوتى: وقد ضمنتُ هذا المستوى الخطأ الإملائي؛ لأنه استبدالُ صوتٍ خطأ بصوت صحيح، وكان غالب تللك الأخطاء الإملائية فيما يأتي:

1-الخلط بين همزتي الوصل والقطع: وهذا الخطأ أكثر الأخطاء اللغوية شيوعًا في أسئلة الاختبار ات، ولم يسلم منه إلا النادر منها. ومن ذلك ورود الفعل الأمر (أكتبْ) هكذا (أُكتبن) بهمزة من فوق الألف، والصواب أن الألف هنا للوصل؛ دون همزة؛ لأنه فعل أمر من الفعل الماضي

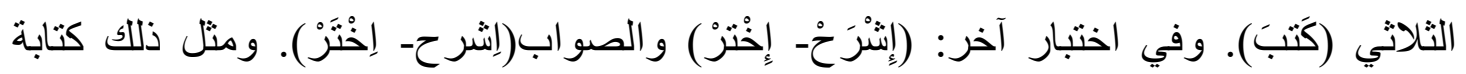

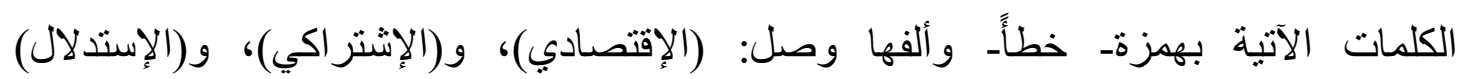
و(الإقتر اض) و(الإحتمالات) و(بطاقة الإتتمان) و(إنشرحْ) و(أملأ) و (أُذكُرْ)، و(إستعيني بالله)، و الصو اب كتابتها جميعا دون هزة. ومنه كتابة (السؤال ألأول)، و(ألاالتين) و(خط ألأعداد)،

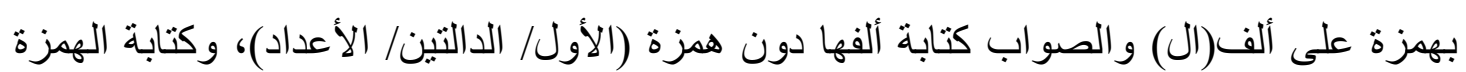
على ألف (أل) هو ما أسمته نظرية تحليل الأخطاء بـ(التعود) على الخطأ، وهو ناتج عن نطق اللام $=323=$ 
مجلة الجمعية المصرية للكمبيوتر التعليمي

الثمسية قمرية_و هي ظاهرة منتشرة عند النساء- فيضطر المتكلم إلى إظهار ألف (أل) نُطقًا، فيظن أنها همزة قطع فيكتب فوقها همزة. و على العكس من ذلك، كتب بعضهم (آجِبْ) و(اثْبُتْْ) بألف

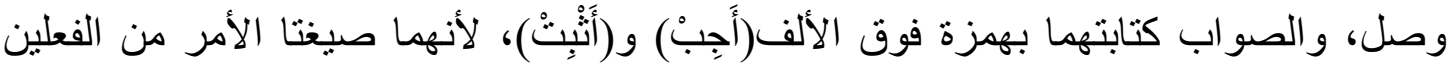
الماضبين الرباعيين(أجابَ) و(أَتْبَتَ) الذي همزتهما قطع. ومثنها كتابة: (إذَا)، و(إنْ) و(آنْ)، و(الاسئلة) و(أَجْدِي- اَوْْد) و(إبعاد)، و(الإجابة) و(الانتاج) و(اعطاه) و(الاخص) و(لِاَحد) و(آكثَرُ) و(اجهزة) و(افلام) و(اَصندرَ) دون همزة و هو خطأ، والصواب كتابتها جمبعا بهمزات

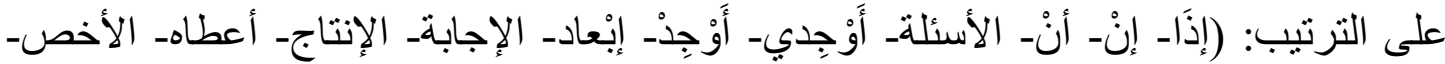
لِأَحد- أَكثرُ- أجهزة- أفلام- أَصْدرَ. وكتابة الأسماء بألف وصل منّل: (الاسفار) و(الاسلامي) و(اسر ائيل) و(اورشليم) و(اهم) و(الارجاء) و(انفسه)) و(اسباط) و(الاشربين) و(الانبياء)، و الصو اب في كل ما سبق: (الأسفار / الإسلامي/ إسر ائيل/ أورشليم/ أهم/ الإرجاء/ أنفسهم/ أسباط/ الأشوريين/ الأنبياء). و هذا الخطأ أكثر من أن نُحصِيَه، ويمكن الرجوع في معرفة قاعدة (الهززة في أول الكلمة) إلى: (عبد العليم إبراهيم،1975م:37 وما بعدها/ عبد السلام هارون،1993: 7 وما بعدها/ عمر الطبََّّاع،1993م: 27/ عبد اللطيف الخطيب،1994م:20/ حسن شحاتة و أحمد حسنين، 1998م: 11 و ما بعدها).

2-كتابة الهمزة التحتيةـ في أول الكثمةـ فوق الألف أو عكس ذلك؛ سهوًا أو جهلً، مثل كتابة (إجازة): (أجازة)، و(أمام):(إمام)، و(الأفراد):(الإفراد)، و(الأعمال):(الإعمال)، و(الإثبات): (الأثبات)، و(إذَا):(أذا)، و هذا مما يغير معنى الكلمة ويُشتّت ذهن الطالب؛ لتحولها إلى كلمة أخرى! فعلى سبيل المثال كلمة(إجازة) مصدر للفعل الرباعي(أجاز)، بمعنى: إذْنْ أو ترخيص، أما(أجازة) بفتح الهمزة فكلمة عامِيَّة مُحَرَّفة عن كسر الهمزة ولا أصل لهافي اللغة(أحمد مختار عمر،2008م: أجز 11/1). و كلمة(أمام) ظرف مكان، بمعنى(قُدَّام)، أما كلمةُ(إمام) فتُطلق على من يُوْْتَمَ به.(مجمع اللغة العربية بالقاهرة(د.ت): أمم/27/)، و هكذا بقية الكلمات.

3-الخلط بين علامة المد فوق الألف والهمزة: فقد وجدث في بعض الاختبارات (السؤال الأتي) بدل(الآتي)، و(الأسئلة الأتية) بدل (الآتية)، و(أراء) بدل(آراء)، و(أتاك) بدل(آتاك)، و(رأه) بدل(ر آه) وكُتبتبت الآية الكريمة (وآتُو ا حَقَّهُهُ يَوْمَ حَصنادِهِ) [الأنعام/141] في أحد الاختبار ات هكذا 
مجلة الجمعية المصرية للكمبيوتز التعليمي

(و أتو)، و(القرأن) بدل(القرآن)، و(أثناره) بدل (آثناره). فقد يغيب عن ذهن بعضهم أن علامة المد فوق الألف(آ) دليل على وجود ألفين هكذا(أ)، حُذِفت الثانية في الرسم وبقيت الأولى مع وضع علامة المد( ) لتدل على المحذوفة. ودخول ألف المد الثانية يكون لعلة صرفية دلالية، فكلمة (الآتي) اسم فاعل بمعنى(النالي)، و(أناك) بهمزة واحدة فعل ماض معناه (جاءك)، و(آتاك) بالمد فعل رباعي ماض على وزن(أُْْعَ) معناه (أعطاك). وكذللك باقي الكلمات، يختلف المعنى بالمد عنه بهزة واحدة(مجمع اللغة العربية بالقاهرة: أتى15/1).

4-الخطأ في كتابة الهمزة وسط الكلمة وآخرها، مثل كلمة (التَّجزِىء) في اختبار التحليل الحقيقي(2) بقسم الرياضيات، حيث يكتبونها: (التَّجزْئ) بهمزة على الياء بعد الزابي المكسورة، دون مد، رغم أن قراعتها بالمد ثم همزة؛ لأن الهمزة الأخيرة إذا كان الحرف الذي قبلها مكسورًا تُكتَب على الياء، و إذا كان ساكِنَا تُكتَبُ على السطر . ومثل كلمة(بَذْه) كُنتبت في اختبار آخر هكذا: (اختلف المؤرخون...في تحديد بدأ نشأة الخوارج)(عبد اللطيف الخطيب، 1994م:46). وفي اختبار ثنالث كُتِبت هزةة(أبطَا) هكذا:(أيهما أبطِى في تسَرُبه؟)، و الصو اب كتابتها على الألف لأن ما قبلها مفتوح. وفي اختبار رابع كُتبتبت كلمة (وَأْد) هكذا: (وما المر اد بؤد البنات؟) و المعروف أن الهمزة المتوسطة_في أغلب حالاتهاـ تُكتب على حسب قاعدة أقوى الحركتين: حركتها وحركة ما قبلها، فأقوى الحركات الكسرة ويناسبها الياء، ثم الضمة ويناسبها الو او، ثم الفتحة ويناسبها الألف، وكلمةُ(وَاد) الهمزة ساكنة وقبلها الواو مفتوحة والفتح أقوى من السكون، فنُكتب على الألف التي تناسب الفتحة. (عبد اللطيف الخطيب،1994م: 51).

5-زيادة صوت في الكلمة: مثل زيادة ألف في الضمير (هو) في جمة: (ما هُوَا [هُوَ] الوصف المناسب...؟) وهو خطأ ناتج عن إثباع فتحة الواو. وكذللك وجدتُ زيادة ألف بعد واو الفعل(أرجو ا)، و الفعل(تدعو) في جملة:(تدعوا إليه حاجة الناس)، ومثل زيادة لام في كلمة (رسول) بأحد الاختبار ات، في حديث: (عن أبي هريرة رضي الله عنه قال: قال لرسول الله صلى الله عليه

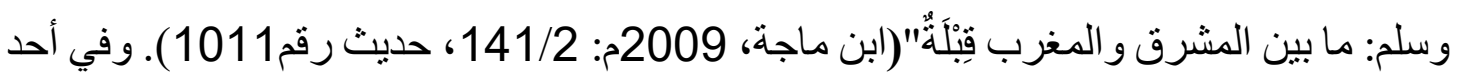
الأسئلة زيادة هاء على آخر كلمة(حُجِيَّة): (مدى حجيته التوقيع الالكترونى في الاثبات) مع ما في السؤال من أخطاء أخرى. وكذلك كتابة ألف(ذا) عند اتصالها بلام البُعْد (ذالك)؛ فهي ألف تُنتق 
مجلة الجمعية المصرية للكمبيوتر التعليمي

لا تُكتب. (مصطفى الغلاييني،1993م: 139/2). ونعد من ذلك إثبات ألف (الرحمان) في البسملةـ في أحد اختبار ات الرياضياتــ والصو اب حذفها في هذه الحالة فقط (بسم الله الرحمن الرحيم)، وكذلك كتابة:( داوود) بو اوين، و الصواب(داود) بو او و احدة. ومنه زيادة نون في كلمة(التتوير) فصارت (التننوير).

6-الخلط بين التاء المربوطة والهاء: ككتابة (مدارِه) بالتاء(مدارة)، في جملة (عندما بدور الإلكترون في مدارة الثابت). وكتابة (رابطه ايونيه) و(رابطه تسانديه)، والصواب (رابطة

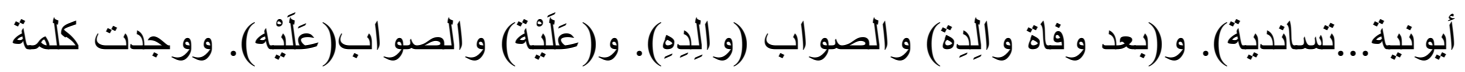

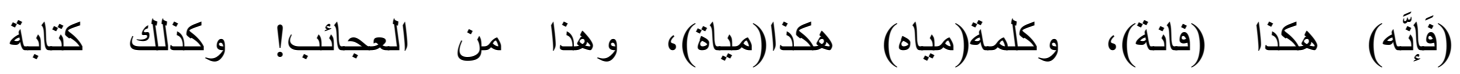
كلمة(القيامه)وكلمة(مكرو هه)-بأحد الاختبار اتـ بالهاء، و الصو اب أنهما بالتاء. و والتاء) و(الهاء) صوتان مختلفان إذا وُضحَ أحدهما مكان الآخر تغيرت الكلمة فيتغير المعنى. ويمكن التفريق بينهما في النطق بطريقة بسيطة، وهي أن الهاء عند الوقف عليها و عند وصلها تُنَقَ هاءً، أما التاء

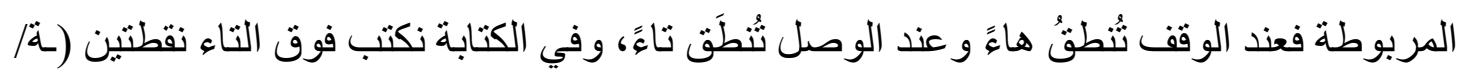

$$
\text { ة)، و الهاء لا نكتب فوقها شينًا (ـه/ ه). }
$$

7-كتابة التاء المربوطة مفتوحة، مثل:(بعد سيطرت الملك عبد العزيز على الحجاز...) والصواب(سيطرة)، لأنها بالتاء المفتوحة فعل ماض متصل بتاء تأنيث أو تاء فاعل، وكلا الاحتمالين مع الفعل لا يناسب الجملة في الدلالة والتركيب. ومثل: (نثأت الثـاعر أحمد شوقي جعلت شعره...)، والصواب (نشأة) بالتاء المربوطة؛ لأن الكلمة مصدر وليست فعلا ماضيًا. وبالجملة فإن كتابة تاء الثأنيت المتصلة بالفعل الماضي تاءً مفتوحة صدارت من البلايا التي ابتليت بها الكتابة العربية في هذا العصر.

8-استبدال الياء بالألف المقصورة، أو استبدال المقصورة بالألف الطويلة، مثل: (التأهيل الأولى للموارد البشرية يهتم بـ...)، والصواب (الأَََّبِيُ). وكتابة (إلى): (إلَّي)، وكتابة (عَلَى): (عَلَي).

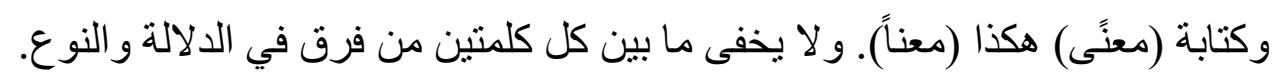


مجلة الجمعية المصرية للكمبيوتر التعليمي

9-سقوط حرف أو أكثر من الكلمة سهوًا أو جهلًا، ومن ذلك: سقوط الميم من كلمة (اللُطلَق) في عبارة: (التحريم الطلق). وترك الألف الفارقة من كلمة(آتُوا) في آية: (وأتو حقه يوم حصاده)؛ فهي ألف تُكتَب و لا ثُنطق. وترك الألف المقصورة من كلمة(مستوَى) في جملة: (يمكن أن تقع في مسنوَ و احد). وسقوط ألف(أل) في كلمة(الغُفْران)، في جملة: (صوم يوم لغفران اهِ صوم عند اليهود).

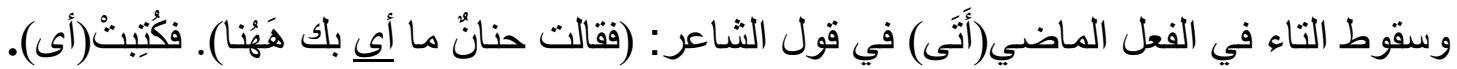
وحذف ألف (ابن) ولم يسبقها عَلَّمَ في جملة: (وهل يصح الاستدلال على عدم وجوبها بحديث بن عمر رضي الله عنه...). وسقوط الميم الثانية من كلمة (أمام) في جملة: (ضع صح أو خطأ أما العبار ات الآتية...). وسقوط هاء الضمير من كلمة (إسناده) في جملة: (الحديث الذي في إسنادِ راوٍ

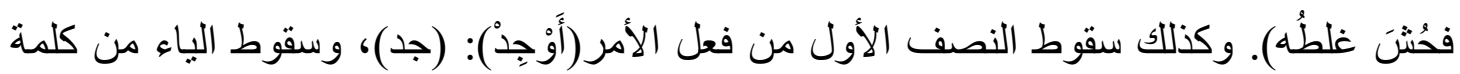
(الدولة العباسية): (العباسة). وحذف ألف(الذي) في السؤال: (ما لذي يترتب على الاحتجاج بالقدر من المفاسد؟). ومن ذلك أيضا سقوط حرف العطف قبل الضمبر(هو) في سؤال يسأل عن الحُكْمِ بمقرر(فقه القضاء): (قضاء القاضي هو غضبان أو به ما يُزعِج). وفي أحد الاختبار ات سقطت الياء المشددة للنسب من كلمة(الكَِّّيُ)، في جملة(العدد الكِم الذي تحدد قيمته شكل المجال...)، وفي اختبار آخر سقطت الياء الثانية من كلمة(يمين)، في جملة(القضاء بشاهدين مُجمع عليه، وبيمن مع شاهد مختلف فيه). وحذف أحدهم اللام الثمسية لأنها مدغمة في الحرف التالي لها فكتب(اتأثر بالانطباع)، يقصد(التأثر)، وبنفس الاختبار سقطت الواو من (وَضْع)، فقال (ضع المعوقات جانبا). و هذا الخطأ مرده-بكل تأكيد- الإسر اع في وضع الاختبار ، مع ترك التدقيق؛ لكنه يُشتت الطالب في رهاع وقت يحتاج فيه إلى التأمل و التركيز .

10-القلب المكاني سهوًا: مثل كتابة (تكمّلي) بدل (تكَلَّمي)، وكتابة (يَقْتُن) بدل (يقتُتُ)، وكتابة (مناعي الزكاة) بدل (مانعي الزكاة)، و هذا سبق قلم لا ريب، لكنه يشتت ذهن الطالب أيضًا.

11-استبدال صوت بصوت سهوًا أو جهلًا، مثل كتابة (المرأة): (المراة)، وكتابة (التعليل): (التغليل)، وكتابة (لم يُذكرَ): (لم يُذْر ). وكتابة (بِأُنَّ): (بان) فيتحول حرف الجر مع(أن) إلى فعل ماض(بانَ) أو إلى اسم فاعل(بانٍ). ومثل وضع الفاء مكان القاف في كلمة(يتقدّم)، فكُتِبت سهوًا (يتفلد)، وكتابة(السيول) بدل(السيوف) في قول الثاعر : (تسيل على حد السيوف نفوسنا وليست 
مجلة الجمعية المصرية للكمبيوتر التعليمي

على غير السيول تسيل). وفي أحد الاختبارات كتابة اسم الثاعر(الثنفرى) هكذا(الثتفرى)، و (بدين اليهودية) هكذا: (بدبن) بالباء، وكتابة كلمة (ناقة) هكذا (نافة) بالفاء. ومن ذلك (للحج مقاصد عظيمة تؤدي لوحدة ألامه الإسلامية) و الصواب(الأمة). و ون ذلك كتابة (شِبْْه المُنحرِف) في اختبار رياضيات: (شية المنحرف) وهذا أيضا سبق قلم، ناتج عن الإسراع في الكتابة وإهمال التدقيق و المر اجعة، لكنه يؤثر في الطلاب أثناء الاختبار، حيث تشوش أفكاره، على حين أنه يحتاج إلى التركيز والثبات لفهم المطلوب. ومثل كتابة (العزوبية) بالذال، في جملة (يعتبر بقاء اليهودي في العذوبية أمر منافيا للاين)، فالثخص العَزَبُ: الذي لم يتزوج، و الفعل(عَزَبَ) مصدره(عُزْبَة وعُزُوبَة)، فالصو اب (بقاء اليهودي في العُرُوبة) إلا إذا اعتبرنا (العزوبية مصدرًا صناعيَّا). (أحمد مختار عمر،1/2008: 533/1)، وكتابة الز اي ذالًا أَعُدهُه من تداخل اللهجة مع الفصحى.

12-إهمال ضبط كلمات تحتاج إلى الضبط، ففي اختبار (فقه الحدود) جاء السؤال: (يشترط للبخاة شر طان بينهما، و إذا تخلف أحد الشرطين فما حكمهم...) فلم تُضبط كلمة (بِيَّنْهُما)، ولم تُكتب فاصلة بَيْنها وبين كلمة(شرطان)؛ مما يؤدي إلى اللبس لدى الطلاب. وكذلك إهمال ضبط كلمة(أرش) في أحد اختبار ات الثريعة: (عللي: يلزم الصغير و الكبير أرش الجناية) وهي بفتح الهمزة وسكون

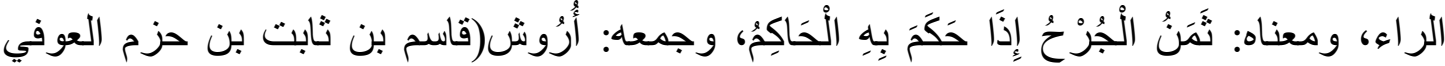

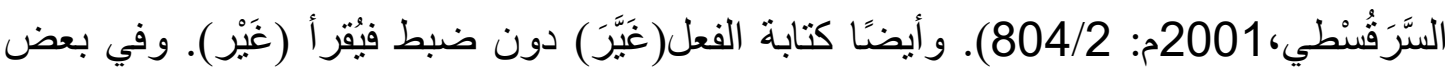
الاختبار ات في سؤال الصح و الخطأ: (كان بعض النساء الحرات يؤدين بعض الأعمال)، دون ضبط (الحر ات)، وهي بضم الحاء يليها راء مشددة مفتوحة، جمع(حُرَّة) وهي التي ليست (أَتَة).

13-الاستخدام الخاطئ لعلامات الترقيم أو إهمالها، فأجد بعض الاختبارات لا تكتب علامة الاستفام(؟) في نهاية السؤال المبدوء بأداة استفهام (ما- ماذا- لماذا- متى- أين- هل- همزة الاستفهام)، وفي بعضها أجد الكاتب بضع علامة الاستفهام في نهاية السؤال المبدوء بفعل

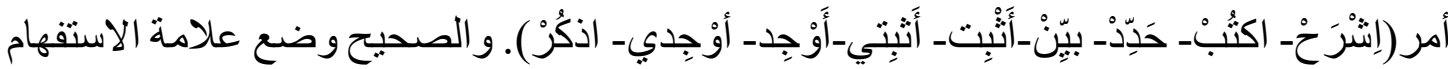
في الجملة المبدو عة بأداة الاستفهام فقط، أو التي يُستفهم بها عن شيء وحُذِفت أداة الاستفهام، نحو: (انتهيتَ من الإجابة؟)، أما الجملة المبدوءة بفعل أمر فتوضع في نهايتها نقطة؛ لأنها جملة تامة المعنى. (عبد اللطيف محمد الخطيب،1994م: 172،171/ناصيف يمين،1999م:274، 275). 
كذلك أجد نسيان استخدام علامات هامة مثل الفاصلة(،) بين جمل السؤال الطويل المكون من عدة مطالب. وترك الثرطنين(- -) المخصصتين للجمل الاعتر اضية. و إهمال وضع نقطة في نهايات الجمل، في بعض الأسئلة. و أحيانا يكتب بعضهم علامتي استفهام في نهاية السؤال(؟؟)، و هذا من الابتداع في الكتابة. ومن إهمال علامة الترقيم التي تؤثر في المعنى ترك وضع الجملة الاعتر اضية بين شرطتين (- -) في جملة (القبول كأحد ضمانات الوفاء بالكمبيالة...)، فلو وضع عبارة (كأحد ضمانات الوفاء) بين شرطتين، أو كَتَبها آخر الجملة (القبول بالكمبيالة، كأحد ضمانات الوفاء...) لكان أوضح للطالب. وكذلك جملة (أخطر ما في الوجودية بعد نفي الألو هية عبادة الذات) لو وضع عبارة (بعد نفي الألو هية) بين شرطتين لكان أوضح و أسلم. ومن إهمال علامات الترقيم التي تُحِِّر الطالب أثناء الاختبار ترك الكاتب وضع فاصلة أو شرطة بين مجمو عة إجابات لأحد الاختيار ات التي يختار ها الطالب من بين أربع مجمو عات بنفس الطريقة، فيقول السؤ ال: (عو ائد عناصر الانتاج تتمثل في:- (أ) العمل رأس المال، الارض، التنظيم (ب) الاجر، الفائدة، الريع الربح (ج) الموارد، التكنولوجيا، المال (د) الاستثمار)، حيث لم يفصل بين(العمل، ورأس المال)، وبين(الريع و الربح).

14- فصل الكلمات الواجب اتصالها في صيغة السؤال، فقد كُتبَ في أحد الأسئلة: (أجب عن ما يأتي)، و الصو اب قلب نون (عن) ميمًا و إدغامها في ميم(ما) لفظًا وخطًا (عمَّا). و فصل (أن) من(لا) في جملة:(يشترط في الغَرر...شروط منها: أن لا ندعوا إليه حاجة الناس)، والمشهور وصل (أن) المصدرية إذا تلاها (لا)، هكذا(ألا تدعو)، على رأي الجمهور ويرى أبو حيان وجوب فصلها في هذه الحالة(عبد اللطيف الخطيب،1994م:95/ مصطفى الغلاييني،1993م: 139/2). 15- إثبات ألف(ما) الاستفهامية إذا سُبِقَت بحرف جر، وحقها أن تُعََف، ومن ذلك (النهي المطلَف علاما يحمل؟)، و الصو اب(عَاَّ)). و أيضا في بعض الأسئلة (فِيما) و الصو اب(فِيمَ)، فترك ألف (ما) الاستفهامية الداخل عليها حرف جر في السؤال، يحولها إلى(ما) الموصولة؛ فيتغير المعنى. ثانيًا:المستوى الصرفي: الأخطاء في هذا المستوى قليلة، مقارنة بالأخطاء الإملائية السابقة التي لها تأثير صرفي، من حيث تغير الصيغة. ومن ذلك استخدام اسم المفعول من الفعل الثلاثي الأجوف (باع) على (المُباع) و(البضاعة المباعة) و الصواب (المَبِيع و المَبِيعة) على وزن(الََفْعِة) $=329=$ 
مجلة الجمعية المصرية للكمبيوتز التعليمي

لأن اسم المفعول من الثناثي بوزن(مفعول) فاجتمع ياء الفعل واو(مفعول)، فحُذِفت واو مفعول على رأي سيبويه، أو عين الفعل على رأي الأخفش ثم قُلبت واو مفعول ياءً لكسرة الباء(سيبويه، 1988م: 348/4، 383؛ ابن الحاجب جمال الدين عثمان بن عمر، 2010م: 91/1). وسبب عدم مجيء اسم المفعول على وزن(مُفْعَل) أن (باع) لا يأتي منه (أباعً) رباعي. ومن ذللك صياغة فعل الأمر للمؤنثة من الفعل (أجابَ) هكذا(أَجِبِي) وهو قياس خاطئ على صيغة الأمر للمفرد المذكر(أَجِبْ)، و الصو اب(أجيبي)². وفي بعض الاختبارات أيضا صياغة ذات الفعل بصيغة المضارع(أَجِبب)، و الصحيح (أَجِبْ). ومن ذلك صياغة الأمر من الفعل الثناثي المثال(وصفت) على (أَوْصِفَ) في أحد اختبار ات الرياضيات، وهو قياس خاطِئ على صيغة الأمر من الفعل

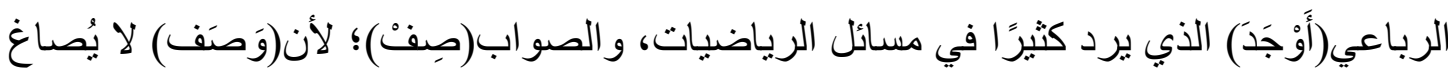
منه رباعي بوزن(أوْصَفَ)، أما (وَجَدَ) فيأتي منها(أَوْجَ). ومن ذللك استخدام فعل الماضي وهو يريد صيغة الأمر ، ففي أحد الخيار ات باختبار مهار ات الاتصال:(تحدى المتحدث)، و الصو اب (تَحَدَّ المتحدث) بتشديد الدال المفتوحة من الفعل؛ لأن السؤال: (لكي تُفْسِد اجتماع: قاطع المتحدث/ غير موضوع الحديث/ تحدى المتحدث/ كل ما سبق)، إضافة إلى الخطأ الإعر ابي في كلمة(اجتماع). ومن ذلك جمع (دعوى) على (دعاوِي)-في أحد اختبارات قسم الأنظمةــ وتكرار هذا الجمع، و الصو اب(دعاوَى). وفي ذات الاختبار استخدام اسم الفاعل مكان اسم المفعول (إذا تعدد المُدَِّعِي عليهم...) و الصو اب(المُدََّعَى عليهم). أما جمع كلمة(مدير ) على (مدر اء)، فقد أجازه المجمع اللغوي بالقاهرة، على توهم أصالة الميم الزائدة فيها(مجمع اللغة العربية بالقاهرة،1989: 150/ 150 أحمد

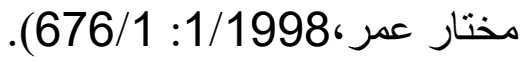

\section{ثُالثًا:المستوى النحوي:}

الأخطاء النحوية في الاختبار ات تشمل أخطاء الإعراب الناتجة عن الجهل بعناصر الجملة الفعلية و الاسمية، وأخطاء تركيب الجملة، بحذف عنصر منها، أو إطالتها بما يُخِل بالمعنى. وأخطاء

2 - - (أَجِيبي) أصله (أَجوِبي) دخله إعلال بالنقل، حيث نقلت كسرة الواو إلى الساكن الصحيح قبله، ثم قلبت الو او ياء لكسر ما قبلها فصار الفعل (أُبِيبي).

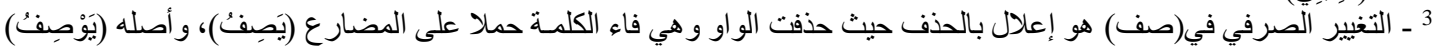
$=330=$ 


\section{مجلة الجمعية المصرية للكمبيوتر التعليمي}

استخدام حرف الجر المناسب، وإعادة ضمير المذكر على المؤنث، وإعادة ضمير المثنى على الجمع. و أخطاء كتابة الأعداد مع تمييز ها، من حيث التذكير و التأنيث، ونوع التمييز (إفر ادًا وجمعًا). و عدم التفريق بين واو الضمير وحرف الواو في الفعل. ونفصل ذلك على النحو الآتي:

1-أخطاء الإعراب: غالب أخطاء الإعراب في حالة نصب الاسم (غير المضاف أو غير المتصل بأل أو غير المنتهي بتاء أو ألف مقصورة أو همزة فوق الألف) أو عند وجود الكلمات التي تُعرَب بالحروف_كالمثنى والأسماء الخمسة وجمع المذكر السالم والأفعال الخمسةـ لأنه لابد من ظهور علامة الإعر اب في هذه الحالات، فمن ليس لديه عِلمّ بالإعر اب و المعنى فمن المحتمل وقو عه في الخطأ. ومن ذلك ما يرد في الأسئلة: (أذكر في نقاط كل مما يلي) و (ناقشن كل مما يلي)، و (وضتح في نقاط كل مما يأتي)، و (أذكُرْ دليل على التقرير بالمال)، و(يلعب دور مؤثر)، و(تُعتَبر تقرير تُفْصح عن الوضع المالي للمنشأة)، و(اذكر ثلاث من أنواع السلع)، و(اذكري ثلاث من فو ائد أدب الخلاف) و(المتغير الاقتصادي يلعب دور مؤثز في حجم عمل المنظمة...)، و(لكي تفسد اجنماع) و(عددي اثثان من مزايا وعيوب التشريع) و(اذكر فرق واحد بين...) والصواب في كل ما

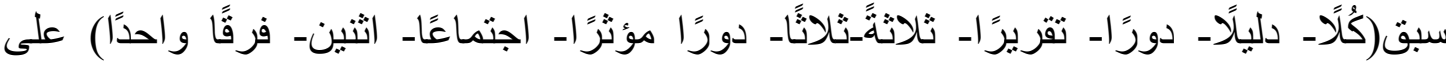
الترتيب. ومن ذلك حذف نون مضارع الأفعال الخمسة، المرفوع منها دون أن يسبقه ناصب أو جازم في أحد اختبارات الرياضيات:(اوجدي حاصل ضرب...ماذا تستتني؟)، والصواب (تستتجين). وفي اختبار (التحليل الإحصائي): (أنثبت أن التقريران التاليان متكافئان)، و الصو اب(أن التقريرين التاليين) لانتصاب الأولى ب(أن) والثانية نعت للأولى. وفي اختبار مقرر(التبولوجيا) بقسم الرياضيات(لتكن النقة "أ" هي عنصر في الفضاء التبولوجي...)، والصو اب(عنصرًا). وفي اختبار رياضيات نالث:(يكون للمعادلة الديوفنتية...حلًّل إذا ...)،

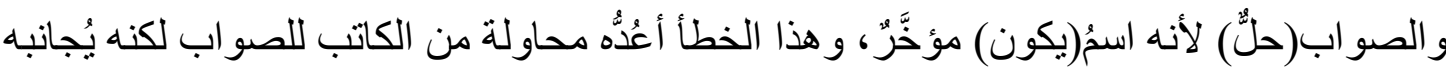
و هو ما يسميه أصحاب نظرية تحليل الأخطاء بـ(الافتر اض الخاطئ). ومن ذلك رفع المضاف إليه المجرور- في أحد اختبارات الفقه-(وكان تاريخ إنشاؤها) و الصو اب(إنشائها)، وفي ذات الاختبار(عرفي الإيلاء و الظهار؟ وما هي كفارة كِلا منهما؟) و الصو اب(كُلِّ) لأنه مضاف إليه.

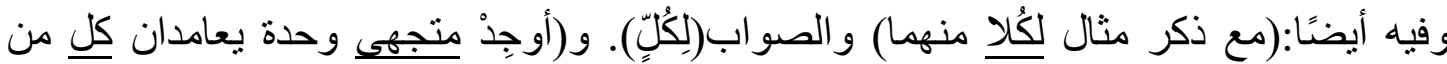
المتجهين...) والصواب(متجَهَيْ...كُلَّل...). ومن ذلكـ- في أحد الاختبارات النهائية لمقرر في ورهي 
مجلة الجمعية المصرية للكمبيوتز التعليمي

الكيمياء- (إذا كان تركيز ايونات الكالسيوم في مياة الثرب 12جزء في المليون فهي...) و الصو اب: (أيونات- مياه- جزءًا). ومن ذلك (عينة من الغاز تشغل 20لتر) و (...ليتغير الحجم الى (ك)لتر)، و الصو اب(20 لنرًا// 70لنرًا). ومن ذلك (من أر اد تعلم المنطق لابد أن يكون عالم بالكتاب و السنة) و الصواب(عالمًا). ومن ذللك في سؤال اختيارات:(يعد حق الملكية: مؤقتــ ضمني- دائم)، و الصواب: (مؤقنًاــ ضمنيَّا دائمًا). ومن ذلك وضع جمع المذكر المرفوع موضع المجرور في قوله:(الليبر الية جوهر أساسي ينفق عليه جميع الليبر اليون...)، والصواب (الليبر اليين). ومن ذلك ما جاء في نهاية أحد الاختبار ات من توقيع واضعي الأسئلة بكلمة (أستاذي المقرر ...و...)، و الصواب (أستاذا المقرر)؛ فقد تحول المعني إلى أن المقرر هو أستاذي! وفي السؤال الاختياري (إذا كانX متغير عشوائي...) جعل الخبر هو اسم كان نكرة، والصواب (متغيّرًا عشوائَّا). وفي ذات الاختبار: (إذا كان المتغير العشوائيل يتبع توزيع ذو حدين)، والصو اب: (يتبع نوزيعًا ذا حَدَّيْن). وفيه أيضًا: (نختار مصباح عشو ائيا من انتاج المصنع)، و الصو اب (مصباحًا عشو ائيَّا من إنتاج المصنع). ومن ذلك الخطأ في علامة إعراب نعت المنصوب، في جملة: (من شروط صحة البيع أن يكون المعقود عليه دينا موصوف في الذمةة) و الصواب (دَيْنًا موصوفًا). و ومنه نصب النعت المرفوع في جملة (اليهود المعاصرين هم من نسل بني إسر ائيل)، و الصو اب(المعاصرون). و ونه ترك نصب المفعول في جملة (المركب الذي لا يُكَِّّن ملح رباعي هو..) و الصو اب(ملحًا رباعِيَّا). ومنه العطف على نائب الفاعل المرفوع بمعطوف مجرور أو منصوب، في جملة (يسري النظام الجنائي على كل من يوجد داخل إقليم الدولة من مو اطنين ويُستثنى منه الأجانب و عديمي الجنسية) و الصواب(و عديمو). ومنه نصب المبتدأ المؤخر في سؤال الصح و الخطأ: (للايهود حقَّا ناريخيًّا

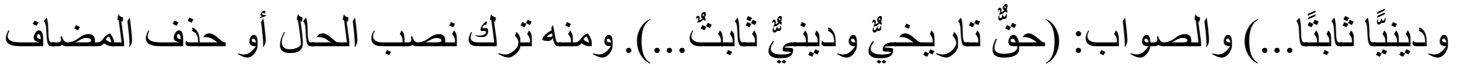
إليه في السؤال (بَيّني خلاف الفقهاء في مسألة تكرار الطلاف ثلاث في مجلس واحد...)، و الصو اب(ثلاثًا) أو(تلاثَ مر اتٍ). و ونه ترك نصب خبر كان، مع نصف المعطوف على مجرور في جملة (المطلقة طلاقار رجعيا إذا توفي عنها زوجها قبل انتهاء عدتها ما لم تكن حامل فإنها تعتد بأربعة أشهر وِشرًا)، الصو اب (ما لم تكن حاملًا...بأربعة أشهرٍ و عثرِ ) .

2-أخطاء تركيب الجملة: ومن ذلك ورود السؤال بصيغة غير صحيحة لُغويَّا مما يؤثر في فهر الطلاب له وبالتالي يؤدي إلى تجنب الإجابة الصحيحة، غالبًا، ومن ذلك فتح همزة(إن) بعد فعل $=332=$ 
القول: (قال أوجست كونت: أنـ مهمة الفلسفة...). وفتحها أيضًا بعد(حيث)، بكثرة في اختبار ات الرياضيات: (بحيث أنّ)، والصو اب كسرها في الموضعين. ومن ذلك (فتح همزة إن) في بداية الجملة (السؤال الثالث: أن للحج مقاصد عظيمة...) و الصو اب كسر ها:(إن للحج)، وكذلك إذا وقعت في جواب الثرط(إذا كان التجزيء...أدق من التجزيء...فأن ...) و الصو اب(فإن). ومن ذلك الخطأ الإملائي الذي غير صيغة الوصف؛ فاختل التركيب، مثل(الوزن الجزيئ)، والصواب كتابتها (الوزن الجُزِيئيُّ) نسبة إلى (الجُزِيء)، أي الوزن المنسوب إلى الجزيء. ومنه حذف واو الحال في الجملة الحالية، مما أخل بمعنى الجملة (قضاء القاضي هو غضبان أو به ما يزعج)، و الصواب (و هو غضبان). ومن ذلك (فهل ما يثبث للناس على بعضهمبموجب العرف)، و الصو اب:(للناس بعضهم على بعض). وفي اختبار رياضيات (إذا كان أن=N= هي مجمو عة الأعداد الطبيعية...) فهذه الجملة بها (أن) زائدة، و الصواب:(إذا كانسX=Nهي مجموعة ....). وفي اختبار آخر في الرياضيات:(تكون متتالية الدوال...متقاربة بانتظام علىD أذا وفقط أذا كان لكل ...) فنجد كتابة (إذا) بهمزة فوق الألف، وتكر ار ها و عطف (فقط) عليها، و الصو اب(تكون منتالية الدوال...متقاربة بانتظام علىD إذا كان لكل ...). ومن ذلك في سؤال إكمال الناقص: (يحتوى تحت الغلافPعلى عدد.....من المسار ات)، وصو اب التركيب:(يوجد تحت الغلافP عدد......من المسارات). وفي ذات الاختبار حذف ضمير يربط جملتين: (وضح التوزيع الالكتروني المختصر لعنصر كيميائي عدد الذري(Z=32)، و الصواب(الإلكتروني-عدده). ومن ذللك: (أثنبت أن ألدالتين التاليتين أحدهما معكوس للأخر)، و الصو اب (الدالتين...إحداهما معكوس للأُخْرَى). ومثنل حذف حرف الجر(في)

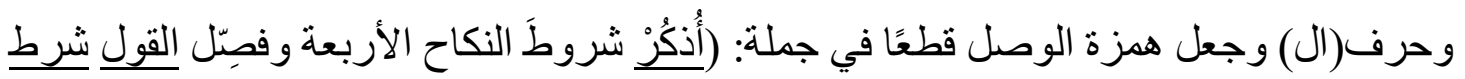
الثاني) مما أخل بالتركيب و أغمض المطلوب، والصو اب:(أْكُكْر شروط النكاح...وفَهِّل القول في الثرط الثاني). ومثل ذلك سقوط (إذا) قبل (أقرَّ)، في جملة: (عرف الإقرار في اصطلاح الفقهاء؟ و عد شروطه الثلاثة، وما الحكم أقر المريض بالمال لو ارثه؟). ومن تداخل اللهجة مع اللغة الفصحى حذف ألف الضمير المؤنث المتصل(ها) في اللهجة السعودية، فنجد في أحد الأسئلة: (... ثم اذكر وجهًا من أوجه المناسبة بين افتتاحية السورة وخاتمتَّه)، والصواب (وخاتمتها). ومن ذللك إعادة ضمير المثنى الغائب على جمع: (...فيني أي من المتباينات الآتية صحيح و أيهما خطأ)، و الصواب إبهاب. (و أيها). ومن ذلك إطالة السؤال بكلمات يمكن الاستغناء عنها، فمن ذلك (علمت أحد مشرفي البيع 
مجلة الجمعية المصرية للكمبيوتر التعليمي

تلقى هدية من عميل بمناسبة قيام هذا المشرف بالتفاني بالقيام بخدمة ما بعد البيع للعميل مار أيك؟)، وكان من الممكن صياغته هكذا: (تلقى أحد مشرفي البيع هدية من عميل لتفانيه في خدمة ما بعد البيع. فمار أيك؟) أو مثل ذلك من تعبير. ومن ذلك استخدام التعبير ات العامية في السؤ ال، كما ورد بأحد الاختبار ات: (مدير الإنتاج يضغط عليك لتعين أحد أقاربه) و الصو اب (يُجبرك) أو (يضطرُّك). ومن ذلك: (القر اءة تبني عند الإنسان اللغة و المهارة الحديث)، و(الدروس التدريبية تعود الطالب على الجر أة الحديث) و الصو اب (ومهارة الحديث/ جر أة الحديث) أو(المهارة في الحديث/ الجرأة في الحديث). ومن ذلك كتابة الفعل(أُنشِيُتْْ) المبني للمجهول، في السؤال: (أنشأت شبكة الانترنت في عام1969)، مما أدى إلى تغيير الجملة وجعلها خالية من فاعل. وقد يحتاج السؤال إلى كلمة توضحه وتبين المطلوب بسهولة، فمن ذلك في سؤال اختيار ات (السلع سريعة التلف: (أ) العرض المرن (ب) العرض قليل المرونة (ج) الطلب عديم المرونة (د) لا نهائي المرونة)، فكان الأولى أن يقول: (تلف السلع بسبب...) أو(سببه). وفي أحد أسئلة الاختيار ات، التي اختل نركيبها لحذف كلمة وتأخير كلمة؛ مما يسبب غموضا للطالب:( من الاعمال غير المحظورة على الموظف الحكومي الاشتغال بالتجارة منها...)، وصواب التركيب: (من الأعمال التجارية غير المحظور على الموظف الحكومي الاشتغال بها...).

3-أخطاء استخدام حرف الجر المناسب: من المشهور في اللغة استخدام الفعل (أرسل) متعديًا بنفسه وبـعدد من حروف الجر، هي:(على وفي و إلى والباء واللام)، ويتحدد المعنى حسب حرف الجر المستخدم، فنقول: أرسل الله عليهح المطر، أي أنزله وسلطه، وأرسل في طلبه، وأرسل إليه وله هدية، وأرسل بعمل كذا، أي وجََّهُ(أحمد مختار عمر،2/2008: 2/ 887)، وفي أحد اختبار ات مهار ات الاتصال، استُخْدِم حرف الجر (على) بمعنى (إلى)، كُتبِب: (تحليل المرسل عليه) ضمن أربع عبار ات يختار الطالب واحدةً منها، وفي ذات الاختبار(من اتصالات العاملين إلى المنظمة) و الصواب(بالمنظمة). و (بزْهِن بأن) و الصواب (برهنْ على أن). وفي أحد أسئلة اختيارات: (الميزة الكبيرة...هي قابلية التنقل به بسهولة أ.الحاسوب المحمول ب.الحاسوب المكتبي ج.الحاسوب المفكرة)، و الصو اب- حتى يتسق التركيب- حرف الجر اللام: (الميزة الكبيرة 
مجلة الجمعية المصرية للكمبيوتر التعليمي

4-أخطاء استخدام العدد مع تمييزه من حيث التذكير والتأتيث ونوع التمييز. وهذا الخطأ من من الكثرة بمكانٍ في الاختبار ات، فمن ذلك:(عدد أعضاء اللجان: 10-20عضو) و الصو اب(عضوًا). و(اذكر ثنلثث من أنواع السلع) و(اذكر ثلاثًا من أصناف المعتدات)، الصواب(ثلاثة)، لأن التمبيز(أنواع) و(أصناف) مفرده (نوع) و(صنف) و هما مذكران. و منثل ما سبق: (التفسير الموضو عي ست مجالات أذكر ثثلاثًا منها)، و الصو اب(ستةـ ثلاثة)، إضافة إلى أن(اذكر) همزة وصل. ومن ذلك (تعرضي بالثرح لخمسة نقاط)، و الصواب(لخمس نقاط)، وهو من القياس الخاطئ. ومن ذلك: (تقديم السيرة الذاتية لأحد الثركات) و الصو اب:((لإحدى الثركات). و (هالكة عن زوج وثمان أخوات) و الصو اب(وثماني). و(أجب عن ثلاث أسئلة) و الصواب(ثلاثة). وفي اختبار مهار ات الاتصال:(اذكر أربعة من وظائف اللغة اللفظية) و الصواب(أربعًا). و على عكس ما سبق: (وللغَيبة أسباب كثيرة اذكر أربعًا منها) و الصو اب(أربعة). و(بين مدى قانونية ثلاثنة من العبار ات الآتية) و الصو اب (ثلاثٍ)؛ لأن العبارة مؤنثة. ومن ذلك (خطو ات توجيه السؤال ثناثة....)، و الصو اب (ثلاث). ومن ذلك:(السؤ ال الثاني: عشرة درجات)، و الصو اب(عشر). ومن ذلك مجيء تمبيز الأعداد من (3-10) مفردة، والصو اب جمعها، وذلك كثير في اختبار ات الكيمياء، فمثلًا: (عينة من الغاز حجمها 6.4كلتر) و(عينة من الغاز تحتوى على2.2مول وحجمها 10.2لتر)، و(اناء

$$
\text { سعته 4لتر) و الصو اب (لتر ات_تحتوي- مولاتـ لترات). }
$$

رابعًا:المستوى الدلالى: المستوى الدلالي لا ينفصل عن المستوى الصوتي أو الصرفي أو النحوي، فكل ما ذُكرَ من أخطاء صوتية أو صرفية أو نحوية أدت في غالبها-إن لم يكن كلها- إلى التغير الدلالي للكلمة؛ فمثلا كتابة (أثار ) مكان (آثار)، أدى إلى تغبير الكلمة المقصودة من جمع (أثر) إلى فحل (ماضٍٍ) له دلالة مختلفة. وكذللك كسر الهمزة في الكلمات: (الأفر اد) و(الأعمال)، و(الأبعاد) يحولها إلى مصادر(الإفراد) و(الإعمال) و(الإبعاد). وكسر هزة(أمام) فتصير(إمامًا)، يغير الكلمة. وفتح همزة (إذا) فتصير(أذا) يحولها من ظرف إلى همزة استفهام داخل على اسم إثارة.

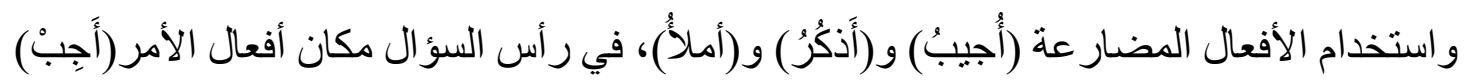
و(أذكُرْ) و(املأُ)، يحول الأمر إلى خبر، مما يفقد السؤال قيمته. وكتابة (بُعفَى)- المفتوح الفاء المبني لغير الفاعل- بكسر الفاء يليه ياء، أدى إلى خلل التركيب:(اذكر الحالات التي يُعِفي الموظف من الالتز ام بـ...). وبكتابة (علَى) و(إلَىى) ويُعطَى) بالياء يتغير المعني. ومن ذلك استخدام كلمة

$$
=335=
$$


مجلة الجمعية المصرية للكبيوتر التعليمي

(الحاجيات)- التي ليس لها معنى في اللغةـ مكان (الحاجات)، وكتابة (المتواجد)- وهي بمعنى الحزين- مكان (الموجود)، وكتابة (اثبت)فعل أمر من الثبات، مكان(أَثتبتُ) أمر من الإثبات. ومثل: سقوط كلمة يُخِل بالمعنى، كما سقطت كلمة (المَبِيت) في جملة: (ما حُكم القَسِْْ بين الزوجات في[...] مع الدليل). ومن ذلك ما ورد في رأس سؤال:(ضع خطا تحت الإجابة الصحيحة مما يلي) من

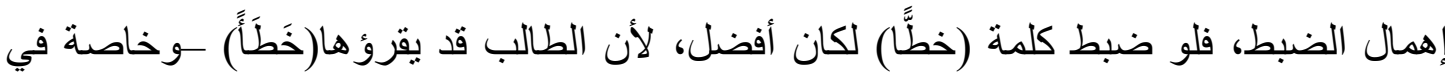
مجتمع بتخلص من الهمز في كلامهـ فيكتب علامة الخطأ تحت الجواب الصحيح فيظن الأستاذ أن هذه الكلمة يستبعدها الطالب! و عندما تُكتب هاء ضمير المذكر المفرد تاءً في كلمة (والده) في

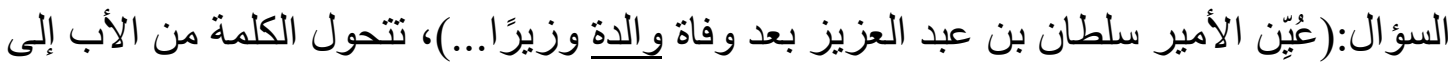
الأم. و على مثل ما سبق أتت بقية الأخطاء وستجد آتار ها في تغير المعنى واختلال التركيب.

\section{المبحث الثالث}

\section{تحليل أخطاء الاختبارات والعلاجات المقترحة}

إن تحليل الأخطاء من مصطلحات علم اللغة النطبيقي المتداول في تعليم اللغة؛ و لا يمكن وضع العلاج الناجع لها إلا بعد تحليلها ومعرفة أسبابها، التي قد تكون راجعة إلى الاستر اتيجية النفسية التي يتبعها المتعلم، و المتعلم هنا هو واضع الأسئلة، على اعتبار كونه متعلمًا للغة، أو راجعةً إلى المادة اللغوية المقدمة للمتعلم، أو إلى التداخل بين اللهجة و اللغة الفصحى، أو إلى المحيط الذي تتم فيه عملية التعلم (عبده الر اجحي،1995م :ص57). هذا على الجانب النظري أما على الجانب التطبيقي، فمن خلال استقراء اختبار ات جامعة القصيم في الفترة من عام(1429-1441هـ)، اتضح أن مُجمل أخطائها اللغوية جاءت على النحو التالي:

1- ترك همزة الألف التي بأول الكلمة جَهْلًَ أو تجاهلًا. 2- الخلط بين الألف المهموزة دون مدو الألف المههوزة المتبو عة بمد، أول الكلمة. 3- الجهل بكتابة الهمزة المتوسطة و المتطرفة. 4- الخلط بين التاء المربوطة و الهاء. 5- الجهل بالواو التي يكتب بعدها الألف الفارقة. 
مجلة الجمعية المصرية للكمبيوتر التعليمي

$$
\text { 6- 6- زيادة بعض الأحرف على الكلمة. }
$$

9- إهمال ضبط الكلمات التي تساعد على النطق الصحيح للكلمة.

10- إهمال علامات الترقيم، ووضع علامة الاستقهام في غير موضعها.

11- صياغة بعض الصيغ الصرفية على خلاف القاعدة، كاسم المفعول من الفعل الأجوف. وفعل الأمر من الفعل المنال. وقياس أمر المؤنث على أمر المذكر في الفعل (أَفْعلَ) المعتل العين. وصياغة الجمع المكسَّر خطأ، و الخلط بين اسم الفاعل واسم المفعول. 12- صياغة السؤ ال بطريقة غير محكمة. 13- استخدام حرف جر لا يتناسب مع مُتعلِّقه (الفعل). 14- الأخطاء الإعر ابية.

15- الخطأ في تذكير الأرقام وتأنيثها مع التمبيز، وفي نوع تمبيز ها إفرادًا وجمعًا.

\section{تحليل أخطاء الاختبار ات:}

يرى الباحث- بعد إمعان الباحث نظره في أخطاء الاختبار ات وتحليلها من ناحية أنو اعها

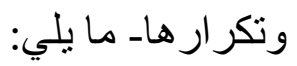

1- انتشار الأخطاء الكتابية بأنو اعها في الاختبارات انتشارًا واسعًا، وخاصة في اختبارات

$$
\text { 2- أغلب الأخطاء إملائية و إعر ابية وتركيبية. الكياء و الفيزياء والأحياء و العلوم الإدارية و علوم الحاسب. }
$$

3- تبيَّن للباحث أن (العجلة) في وضع الاختبار سبب أغلب الأخطاء؛ لاتصال أيام الاختبار ات بأيام التدريس دونما فاصلٍ زمنيّ، إضافة إلى انشغال أعضاء هيئة التدريس بأعمال و أنشطة أخرى، تسبب له تز احمًا على وقته؛ فيُسرع في كتابة الأسئلة بغير تأمل وبغير تدقيق. و الذي دعا الباحث إلى هذا التعليل أنه أحيانًا ما يجد الكلمة المكتوبة خطاً في سؤال قد أعبد كتابتُها صحيحةً في سؤال آخر في ذات الاختبار، أو كتابة الكلمة فيها قلب مكاني(يقتن/ يقنن)، أو سقوط حرف منها (الذي/ لذي)، أو فيها تصحيف (الثنفرى/ 
مجلة الجمعية المصرية للكمبيوتز التعليمي

الثتفرى)، أو زيادة حرف(التتويري/ التننويري)؛ مما يؤكِدّ على أنها أخطاء غير مقصودة لا يمكن وقو عها إلا عن طريق السر عة في الكتابة. 4- (اللامبالاة) في الكتابة، أو الجهل بالقاعدة، قد يكونا سبيًا في وقوع الخطأ بدليل تكرار الخطأ الواحد، في ذات الاختبار ، مثل كتابة(إذا): (أذا)، وكتابة(إنْ): (أنْ)، ووضع همزة على ألف(أل)، وكتابة (الآخر): (الأخر)، ومثل فتح همزة(إنَّ) في بداية الكلام. 5- بعض الأخطاء سببها (القياس الخاطئ)؛ مثل كتابة (أَجِبي) في أمر المؤنث؛ قياسًا على(أجِبْ) في أمر المذكر. ومثل كتابة (أجب عن ثناث أسئلة)، حيث ذكَّرَ العدد لأن(أسئلة) مؤنث، والصواب اعتبار المفرد في التمبيز-(سؤال)- وليس الجمع. ومن ذلك صياغة الأمر من الفعل الثناثي المثال(وصفت) على (أَوْهِفَ) في أحد اختبارات الرياضيات، و هو قياس خاطِئ على صيغة الأمر من الفعل الرباعي(أَوْجَدَ) الذي يرد كثنيرًا في مسائل الرياضيات، و الصواب(صِفْ)؛ لأن(وَصَف) لا بُصَاغ منه رباعي

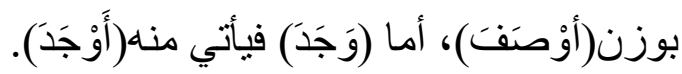
6- (الافتراض الخاطئ) من الكاتب أحد أسباب وقوع الأخطاء؛ كما تقول أصحاب نظرية

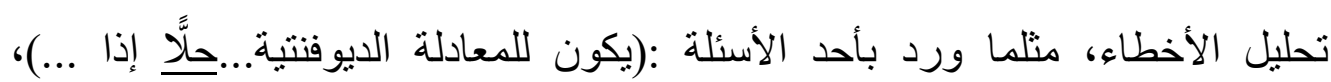

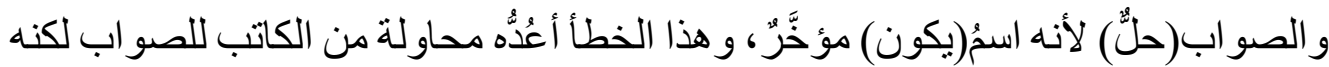
يُجانبه.

7- قد يقع الخطأ بسبب (تداخل اللهجة مع اللغة الفصحى)، مثل: (مدير الإنتاج يضغط عليك لتعين أحد أقاربه) وكلمة(يضغط) بمعنى(يضطر) أو(يُجْبِر) شائعة في عامية مصر التِ و غير ها. ومثل حذف ألف الضمير المؤنث المتصل(ها) في اللهجة السعودية، فنجد في أحد

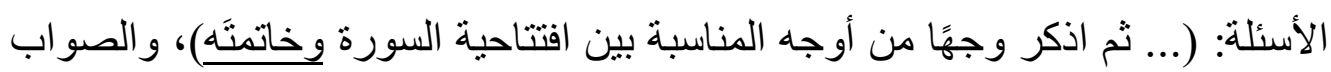
(وخاتمتها). ومن ذلك كتابة الزاي ذالاً في كلمة (العذوبيَّة) هكذا في أحد الاختبارات الإلكترونية، والصواب(العزوبية) بالزاي. ومنه كتابة كلمة (بحديث بن عمر) دون

$$
\text { ألف (ابن)؛ لأنها ثُقر أ في بعض اللهجات (بنْ عمر ). }
$$

8- قد يقع الخطأ بسبب (نسيان القاعدة) التي دُرِسَت من قَبْلُ، مثل الأخطاء الإعر ابية، وكثير من الأخطاء الإملائية البسيطة. 
مجلة الجمعية المصرية للكمبيوتر التعليمي

9- (تعود الخطأ) نتيجة النطق الخطأ للكلمة؛ فيكتبها خطأ، نحو كتابة همزة على ألف (أل)،

في مثل: (السؤ ال ألأول)، و(ألدالتين) و(خط ألأعداد)، و الصواب كتابة ألفها دون همزة في جميعها (الأول/ الدالتين/ الأعداد)، وكتابة الههزة على ألف (أل) ناتج عن نطق اللام الثمسية قمرية-وهي ظاهرة منتشرة عند النساء- فيضطر المتكلم إلى إظهار ألف (أل) نطقًا، فيظن أنها همزة قطع فيكتب فوقها همزة.

\section{استراتيجية تجنب الخطأ اللغوي في وضع أسئلة الاختبارات:}

الخطأ الإملائي إذا وقع من الأستاذ- وهو قدوة الطالب ومعلمه- يؤكد لبعض الطلاب أن ذللك هو الصو اب؛ مما بعمل على تثبيت الخطأ لديه و الالتز ام به في كتاباته، أما الغالبية من الطلاب و هم(72.8\%) حسب نتائج الاستطلاع فيعرفون الخطأ الإملائي الواقع في الأسئلة، و(52.7\%) منهم بعلمون الخطأ الإعر ابي، مما يؤثر في منزلة الأستاذ عند طلابه، وبالتالي تسقط مكانته العلمية عندهم. فالأخطاء الكتابية عند أساتذة جامعة القصيم-في اختبار اتهم- كثيرة ومتفشية تفثِّيًا و اسعًا، و هم قائمون بالتدريس ومستمرون فيه، لذا فوضع استر اتيجية لغوية تثقيفية توعوية لهم؛ لتجنب الأخطاء اللغوية، لابد أن تكون عاجلة سهلة التنفي؛ لأنتا أمام مشكلة كبيرة تتطلب حلًّ سريعًا، وهذه الاستراتيجية يقع تتفيذها على عاتق مسؤولي الجامعة. ويرى الباحث أن ثُنَّنْ تثلك الاستر اتيجية علمى النحو التالمي:

1- تدريب أعضاء هيئة التدريس على الصياغة الصحيحة لعبار ات الأسئلة، من خلال مركز تتمية القيادات و القدرات بالجامعة، ويكون التدريب إلز اميَّاــ في بداية كل فصل دراسيّة، وخاصة للأساتذة-رجالًا ونساءً في التخصصات العلمية و النظرية غير اللغوية؛ فقد انتشرت

$$
\text { الأخطاء في اختبار اتهم انتشارًا و اسعًا. }
$$

2- عقد دورة تدريبية إلزاميةـ في مهارة الكتابةـ بداية كل فصل دراسيّ، للأساتذة الجدد بالجامعة و المعيدين و المحاضرين، أُسوة بالدورات التي تقدم لهم في طرق التدريس و اللغة الإنجليز به. 3- تقديم دورات تدريبية تربوية لصياغة الأسئلة بطربقة فنية صحيحة. 
مجلة الجمعية المصرية للكمبيوتر التعليمي

4- تشكيل لجنة بكل كلية، أو بكل قسم لمر اجعة أسئلة الاختبار ات، ويُفَضَّلَ أن تكون من أعضيهاء

لجنة الاختبار ات.

5- وضع نموذج شامل لعناوين أسئلة الاختبار ات، يُقَّم للأساتذة قبل الاختبار ات.

6- وضع قائمة بالأخطاء الثائعة في أسئلة الاختبار ات مع صوابها، وتقديمها للأساتذة قبل

الاختبار ات، و هذه سيتكفل بها الباحث-إن شاء اللهـ ويقدمها للقيادات الإدارية بالجامعة. 7- تقديم حافز معنوي (مثل شهادات التقدير) لكل أستاذ خلت اختبار اته من الأخطاء الكتابية و الفنية، أسوة بالحو افز التي تُعطَى لمقدمي أنشطة الجودة و أنشطة خدمة المجتمع و الأنشطة

الطلابية.

وهذه بعض النصائح التي تُجنبّبــ واضعي الأسئلةـــ أخطاء الكتابة وخاصة في الاختبارات:

1- الاعتناء بورقة الأسئلة لأنها عنو ان الأستاذ و انعكاس لفكره و علمه، وهي حُجَّة له أو عليه. 2- التمهل في كتابة الأسئلة، ومنحها وقتًا أطول من ذي قبل. 3- إيجاز السؤال، بقدر المستطاع؛ حتى لا يتشتت الطالب، فمن نتائج استطلاع الدراسة أن(82\%) من الطلاب متفقون على أن طول السؤ ال يؤثر في فهمه لله. 4- اختيار الكلمات الواضحة والألفاظ المعهودة الفصيحة؛ فقد أعربَ(58.5\%) من عينة الاستطلاع عن صعوبة فهمه بسبب وجود ألفاظ صعبة.

5- ضبط الكلمات التي قت تحتمل أكثر من معنى، فقد أكد ما نسبته(50.9\%) من عينة الاستطلاع أنهم لا يفهمون السؤال بسهولة، وما ذلك إلا لطول السؤال أو صعوبة ألفاظه أو ترك ضبط الكلمات المحتَمِلة.

6- استخدام علامات الترقيم بدقة، مثل: الفاصلة و الشرطتين و علامة الاستفهام، وخاصة عند تعدد المطلوب في سؤال واحد، فمن نتيجة الاستطلاع أن (63\%) من الطلاب لا يفهون السؤال الخالي من علامات الترقيم، أما (84.3\%) منهم فيرون أن علامات الترقيم

$$
\text { تساعدهم في فهم السؤال. }
$$

7- الاهتمام بكتابة الهمز ات بطريقة صحيحة، وكذلك الهاء المربوطة والتاء المربوطة، حيث

يرى (71.6\%) من عينة الطلاب أن الخطأ الإملائي يؤثر في فهمه السؤال. 
مجلة الجمعية المصرية للكمبيوتز التعليمي

8- الانتباه عند نسخ اختبار قديم لاختبار جديد؛ من تعديل التاريخ واسم الاختبار و الدرجات

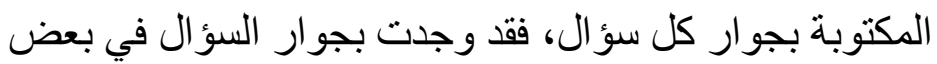

الاختبار ات(20درجات/12درجات)، و الصو اب (20درجة/ 12درجة) ولكن العجلة

$$
\text { تؤدي إلى ذلك. }
$$

9- المر اجعة الدقيقة للاختبار بعد كتابته، و إذا التبس عليك كلمة أو صيغة سؤال، فاسأل أحد المختصين عن تللك الكلمة أو الصيغة بعينها فقط، دونما عرض الاختبار كله عليه. أن ينمِّي الأستاذ معار فه من اللغة، بقر اعة الأشعار و القصص المكتوبة بالفصحى،

$$
\text { وكتب كبار الكتاب. }
$$

الإصر ار على تجنب الأخطاء الكتابية خير دافع للنجاح في ذلك بشتى الطرق.

أما بالنسبة لاستراتيجية التعليم على مستوى القاعدة؛ لتعليم الناشئة الكتابة الصحيحة وتجنيبهم الأخطاء، فتكون على النحو التالي:

1- الاهتمام بدرس الإملاء اهتمامًا كبيرًا في المرحلتين الابتدائية و المتوسطة(الإعدادية). 2- تيسير درس كتابة الهمزة أول الكلمة ووسطها وآخر ها، والتدرب على نطقها، مع كثرة الأمثلة و التدريبات.

3- التقريق بين الألف المهموزة أول الكلمة و الألف التي بعدها مد، مع الأمثلة و التدريبات. 4- زيادة الاهتمام بالتاء المربوطة و المفتوحة و الهاء، مع كثرة الأمثلة و التدريبات. 5- تنبيه المعلمين لطلابهم على علامات الترقيم ومو اضع كتابتها. 6- تدريب الطلاب على التفرقة بين الألف المقصورة القائمة والثبيهة بالياء، ومو اضع كلٍ. 7- تتبيه الطلاب على التفرقة بين واو الجماعة(الضمير)، و واو الفعل(الحرف). 8- تدريب الطلاب على الكلمات ذات الحروف التي ثُنَقَ و لا تُكتَب و الحروف التي تُكتَب و لا تُنطق. 9- تدريب الطلاب على كتابة التنوين، وخصوصًا تنوين النصب. 10- تدريب الطلاب على الكلمات التي توصل بما بعدها، والتي تُقصل عما بعدها، وبيان اختلاف الدلالة في كل منهما. 
مجلة الجمعية المصرية للكمبيوتر التعليمي

التأكيد على الطلاب بأن الأخطاء الإملائية يصاحبها اختلاف في الدلالة، مع معهديه

ضرب الأمثلة المؤكدة على ذلك.

تدريب الطلاب على الصياغة الصرفية الصحيحة، وخاصة من الأفعال التي بها

حرف علة.

الاهتمام بلرس حروف الجر ومعاني تلك الحروف.

$-13$

الاهنمام بدرس الأرقام وتمييز ها، والتدريب عليه بتوسع.

$-14$

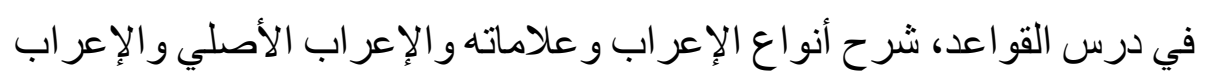

$$
\text { الفرعي، و التدريب عليه في الجمل. }
$$

16- التركيز على شر ح بعض الوظائف النحوية الأساسية، كالفاعل و المفاعيل، و المبتدأ والخبر، و على الأساليب الكثيرة الاستخدام، كأسلوب الاستفهام والتعجب والاستثناء

$$
\text { و التحذير و الثرط و النداء و المدح و الذم، و التدريب عليها. }
$$

\section{نتائج البحث}

من خلال استعر اض الأخطاء وتصنيفها وتحليلها توصل البحث إلى النتائج التالية، التي أجابت عن أسئلة الدر اسة الأربعة الاخط، وهي كالتالي:

1- ما تأثثير الأخطاء اللغوية في فهم الطلاب للأسئلة؟

تبين من خلال استطلاع رأي الطلاب أن (71.6\%) منهم يُوَّبِّر الخطأ الإملائي في فهمه

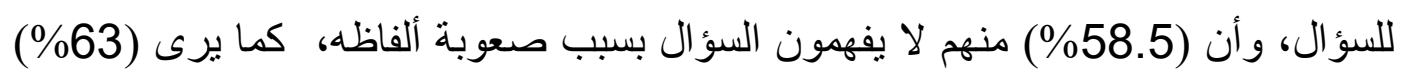
من الطلاب أنهم لا يفهمون السؤال الخالي من علامات الترقيم، أما (84.3\%) منهم فيرون أن علامات الترقيم تساعدهم في فهم السؤال، كما أعربَ(58.5\%) من عينة الاستطلاع عن عن عان صعوبة فهمهم بسبب وجود ألفاظصعبة. وأن(82\%) من الطلاب متفقون على أن طول السؤ ال يؤثر في فهمه لله. و هذه النسب تتو افق مع ما عرضته الدراسة في بداية المبحث الثاني من تغير دلالة الجملة بسبب الأخطاء الإملائية والنحوية والصرفية وتغير علامات الترقيم. 
مجلة الجمعية المصرية للكمبيوتز التعليمي

2-ما الأسباب التي أدت إلى وقوع الأخطاء اللغوية في أسئلة الاختبار ات؟

من خلال تحليل أخطاء الاختبار ات بجامعة القصيم تبين أن أسباب وقو عها: السر عة في كتابتها و قلة الاهتمام بالصباغة، ونسيان القاعدة اللغوية، و القياس الخاطئ، و الافتر اض الخاطئ، وتداخل لهجة واضع الأسئلة مع اللغة الفصحى، وتعوُّد الخطأ.

3- ما أنواع تللك الأخطاء اللغوية؟ وكانت النتيجة المتعلقة بهذا السؤال، التي ظهرت من خلال تحليل الأخطاء- في المبحث الثانيأن أخطاء الاختبار ات تمثلت في: أــ الأخطاء الإملائية المتمثلة في الخلط بين هزة الوصل وهزة القطع، و الخطأ في نطق اللام الثمسية، و الخطأ في كتابة الهمزة المتوسطة و المتطرفة. و الخلط بين علامة الهمزة و علامة المد. و الخلط بين الهاء و التاء المربوطة، وبين التاء المفتوحة والتاء المربوطة. ونسيان بعض حروف الكلمة وزيادة بعض أحرف الكلمة. وكتابة حرف خطأ مكان حرف صحيح. و إهمال علامات الترقيم.

بـ الأخطاء الصرفية، المتمثلة في الصياغة الخطأ لفعل الأمر، و الخلط بين الفعل الثلاثي و الفعل الرباعي، والعجز عن التقريق بين اسم الفاعل أو اسم المفعول، و الخطأ في صياغة اسم المفعول من الفعل الأجوف. ج- الأخطاء النحوية المتمثلة في أخطاء الإعراب؛ المبنية على الجهل بعناصر الجملة الفعلية والاسمية. وأخطاء ترتيب عناصر الجملة، أو حذف عنصر منها، أو تطويل الجملة بما يخل بمضمونها، أو إعادة ضمير المذكر على المؤنث، أو إعادة ضمير المثنى على الجمع. أو تغيير حرف الجر. أو الخلط بين واو الفعل و واو الضمير في الفعل. والخطأ في تذكير العدد و تأنيثه مع المعدود. دـ الأخطاء الدلالية المتمثلة في وضع لفظة عامِيَّة مكان لفظة فصيحة. أو لفظة غير مناسبة (متو اجد)، مكان اللفظة المناسبة(موجود)، لأن بينهما تشابهًا في الحروف. أو وضع جمع مكان مفرد، أو تغيير أحد الحروف فتتغير الكلمة ويتغير المعنى؛ كما أن الأخطاء الإملائية و الصرفية و النحوية ينبني عليها تغيُرُ الدلالة. 4-ما الوسائل الكفيلة بمعالجة هذه الأخطاء أو الحد منها؟ $=343=$ 
مجلة الجمعية المصرية للكمبيوتز التعليمي

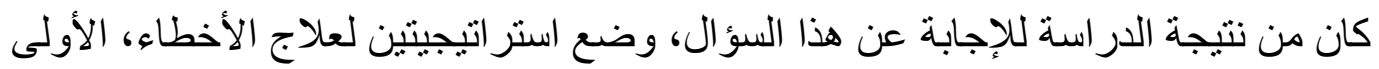
عاجلة تتمثل في عقد دور ات للأساتذة- في عمادة تنمية القيادات و القدرات بجامعة القصيم- في بداية كل فصل در اسي حول الصياغة الصحيحة لبناء الاختبار ات. وكتابة قائمة بالأخطاء الواردة في الاختبار ات مع تصويبها(وهي ملحقة بهذا البحث)، توزع على كليات الجامعة. وتكليف لجنة

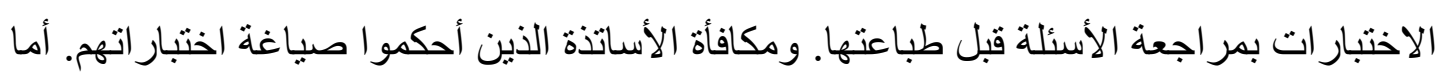
الاستر اتيجية البعيدة المدى فتُنَفٌْ أثناء تعليم الطلاب اللغة، وتركز على الأخطاء التي يكثر الوقوع فيها و الإكثار من التنريب على قو اعدها. 
مجلة الجمعية المصرية للكمبيوتر التعليمي

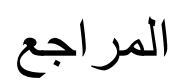

1- إير اهيم الثمسان أبو أوس (1420هـ)، مجابهة الضعف اللغوي، مجلة العقيق، المجلد

$$
\text { الثاني عشر، العدد(23، 24)، (محرم- ربيع الثاني). }
$$

2- أحمد محمد عبد الرحمن(2011م)، تصميم الاختبار ات أسس نظرية وتطبيقات عملية، دار أسامة للنشر والتوزيع، عمّان، الأردن، الطبعة الأولى. 3- أحمد مختار عمر(1991م)، أخطاء اللغة العربية المعاصرة عند الكتاب و الإذاعيين، مكتبة عالم الكتب، مصر.

4- أحمد مختار عمر(2008م/1)، معجم الصواب اللغوي، عالم الكتب، القاهرة، مصر،

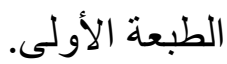

5- أحمد مختار عمر(2008م/2)، معجم اللغة العربية المعاصرة، عالم الكتب، القاهرة، مصر ، الطبعة الأولى. - مصلى 6- أحمد مصطفى أبو الخير(2006م)، علم اللغة التطبيقي بحوث ودر اسات، دار الأصدقاء للطباعة، المنصورة، جمهورية مصر العربية. 7- الأزهري، أبو منصور محمد بن أحمد(2001م)، تهذيب اللغة، تحقيق محمد عوض مر عب، دار إحياء التراث العربي، بيروت، لبنان، الطبعة الأولى.

8- أسـماء السيد محمود. (2011). تطوير الاختبارات الإككترونية للتلاميذ الصـم وتوظيفها بالمرحلة الابتدائية. رسالة ماجستير غير منشورة، كلية التربية جامعة حلوان. 9- إمطانيوس نايف ميخائيل(2016م)، بناء الاختبار ات و المقاييس النفسية والتربوية وتقنيتها، دار الأعصار العلمي للنشر والتوزيع، عمان، الأردن، الطبعة الأولى. 10- أيمن أحمــ الجوهري. (2011). أثر العلاقــة بين متغيرات إنتـاج الاختبـارات وبين الأسـلوب المعرفي على معدل أداء المتعلمين. رسـالة دكتوراه غير منشـورة، كلية التربية جامعة حلوان.

11- إيناس محمد الحسيني مندور . (2013). أثر برنامج تدريبي لطلاب الدراسات العليا بكلية التربية في تصميم الاختبارات الإكترونية وفقًا لمعايير الجودة المقترحة. دراسات

$$
\begin{aligned}
& 460-391 \text { تربوية واجتماعية، } 19 \text { (2)، } 4 \text { (2) }= \\
= & 345=
\end{aligned}
$$


مجلة الجمعية المصرية للكمبيوتر التعليمي

12- ابن الحاجب عثمان بن عمر بن أبي بكر بن بونس، أبو عمرو جمال الدين الكردي المالكي(2010م)، الثـافية في علمي التصريف والخط، تحقيق صالح عبد العظيم الثـاعر، مكتبة الآداب، القاهرة، مصر ، الطبعة الأولى.

13- جاسم علي جاسم(2009م)، نظرية تحليل الأخطاء في التراث العربي، "عين" مجلة الجمعية العلمبة السعودية للغات و الترجمة. 2009م. العدد الرابع، السنة الثانية. (ص237-

14- جامعة الإمام محمد بن سعود(1992)، ظاهرة الضعف العام في استعمال اللغة العربية، الرياض. 15 - جامعة الكويت(1979م)، ندوة مشكلات اللغة العربية على مستوى الجامعة في دول الخليج و الجزيرة العربية، الكويت (الفترة 4-6نوفمبر، ص 90-97). 16- جلايلي سمية(2017م)، اللسانيات التطبيقية مفهومها ومجالاتها، مجلة الأثر، الجزائر، العدد29، ديسمبر.

17-جمال مصطفى شتا(2020م)، اللغويات التطبيقية و أخطاء متعلمي اللغة الأصليين في مو اقع التو اصل الاجتماعي: المتو اصلون المصريون و السعوديون أنموذجًا، مجلة الجمعية المصرية للكمبيوثر التعليمي، المجلد الثامن، العدد الأول، يونيو، ص(341-

18- الحريري، القاسم بن علي بن محمد(1996م)، درة الغوّاص في أوهام الخو اصّ، تحقيق عبد الحفيظ فر غلي علي القرني، دار الجيل بيروتـ مكتبة التراث الإسلامي القاهرة، ط الأو لمى.

19- حسن شحاتة، و أحمد طاهر حسنين(1998م)، قو اعد الإملاء العربي بين النظرية و التطبيق، مكتبة الدار العربية للكتاب (د.ت).

20- حمدي عبدالله عبد العظيم(2013م)، موسو عة الاختبار ات و المقاييس، مكتبة أولاد الثيخ للتراث، الجيزة، مصر.

21- أبو داود سليمان بن الأشعث السِِّجنتاني(2009 م)، سنن أبي داود، تحقيق: شعَيب الأرنؤوط، و محَمَّد كامِل قره بللي، دار الرسالة العالمية، ط. الأولى. $=346=$ 
مجلة الجمعية المصرية للكمبيوتز التعليمي

22- رشدي أحمد طعيمة(2004م)، المهار ات اللغوية، مستو ياتها تدريسها صعوباتها، دار

الفكر العربي، القاهرة، مصر ، الطبعة الأولى.

23- الزمخشري، أبو القاسم محمود بن عمر(1998م)، أساس البلاغة، تحقيق محمد باسل

عيون السود، دار الكتب العلمية، بيروت، لبنان، الطبعة الأولى.

24- س. بيت كوردر(1976م)، مدخل إلى اللغويات التطبيقية، ترجمة جمال صبري، مجلة

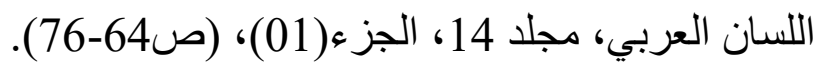

25- سليمان يوسف خاطر(1429 هـ)، الأخطاء اللغوية في صباغة الاختبار ات النهائية

أسبابها و أنماطها و علاجها: در اسة وصفية تحليلية تقويمية، مجلة الجمعية العلمية

السعودية للغة العربية، العدد الثاني، ذو الحجة(صن2584-304).

26- سيبويه، عمرو بن عثمان بن قنبر(1988م)، الكتاب، تحقيق عبدالسلام محمد هارون، مكتبة الخانجي بالقاهرة، الطبعة الثالثة.

27- شارل بوتون(د.ت)، اللسانيات التطبيقية، ترجمة قاسم المقداد، ومحمد المصري، دار

الوسيم للخدمات الطباعية، دمثق، سوريا.

28- صفاء عبد العزيز سلطان(2009م): "الأخطاء اللغوية الثائعة في البحوث التربوية المنشورة تشخيصها ومقترحات علاجها" مجلة دراسات عربية في التربية وعلم النفس،

المجلد الثالث، العدد الأول يناير(243-270).

29- عبد الرحمن أحمد سالم،2020م: أثر التفاعل في الاختبار ات الإلكترونية بين ترتيب

الأسئلة ونمط عرضها في التحصيل والأداء المهاري و الاتجاه نحوها لدى طلاب

الدراسات العليا بجامعة القصيم، المجلة العلمية للكمبيوتر التعليمي، مجلة البحث العلمي

في التربية، العدد (21) يونيو.

30- عبد السلام محمد هارون(1993م)، قو اعد الإملاء، مكتبة الأنجلو المصرية، القاهرة،

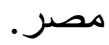

31- عبد العزيز إبر اهيم العصيلي(2006م)، علم اللغة النفسي، عمادة البحث العلمي، جامعة الإمام محمد بن سعود الإسلامية، المملكة العربية السعودية. 
مجلة الجمعية المصرية للكمبيوتر التعليمي

32- عبد العليم إبر اهيم(1975م)، الإملاء و الترقيم في الكتابة العربية، مكتبة غريب،

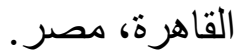

33- عبد القدوس الأنصاري(2006م)، إصلاحات في لغة الكتابة والأدب، ط1، دار المنهل،

جدة، المملكة العربية السعودية.

34- عبد اللطيف محمد الخطيب(1994م)، أصول الإملاء، دار سعد الدين، دمشق، سوريا،

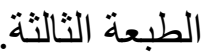

35- عبد المنعم الجاسم(2019م): الأخطاء الإملائية في اختبار ات المستوى المتوسيّ الأوسط: در اسة تحليلية تقويمية في المعهد العالي للّغات بجامعة دمشق، مجلة جامعة

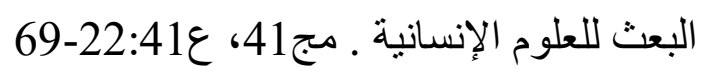

36- عبده الر اجحي(1995م)، علم اللغة التطبيقي وتعليم العربية، دار المعرفة الجامعية،

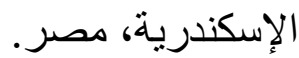

37- عمر فاروق الطباع(1993م)، الوسيط في قو اعد الإملاء والإنشاء، مكتبة المعارف، بيروت، لبنان، الطبعة الأولى.

38- الفارسي، الحسن بن أحمد بن عبد الغفار (1990م)، التعليقة على كتاب سيبويه، تحقيق عوض بن حمد القوزي، الطبعة الأولى، المكتبة الثاملة. 39- فهد عبد الله الخزي(2010). أثر قلق الاختبار وبعض المتغيرات الديموغرافية على أداء طلبة جامعة الكويت في الاختبارات الإكترونية: دراسة وصفية ارتباطية. مجلة جامعة صنعاء للعلوم التربوية والنفسية، 7 (1)، 221- 267. 40- فيصل عباس(1996م)، الاختبار ات النفسية تقنياتها و إجر اءاتها، دار الفكر العربي، بيروت، لبنان، الطبعة الأولى.

41- قاسم بن ثابت بن حزم العوفي السرقسطي أبو محمد،2001م، الدلائل في غريب الحديث، تحقيق محمد بن عبد الله القناص، مكتبة العبيكان، الرياض، السعودية، الطبعة

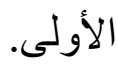


مجلة الجمعية المصرية للكمبيوتر التعليمي

42 كهينة شابي، وسهام خلافي(2017م)، تحليل الأخطاء اللغوية في اللافتات و اللوحات الإعلانية التجارية بمنطقة بجاية در اسة في ضوء اللسانيات التّطبيقية، ماجستير، بجامعة عبد الرحمن ميرة بجاية، كلية اللغة العربية و آدابها، بالجز ائر. 43ـ ليونا أ. تايلر (1998م)، الاختبار ات و المقاييس، ترجمة سعد عبد الرحمن، مر اجعة محمد عثمان نجاتي، مؤسسة الأهر ام للنشر والتوزيع. القاهرة، مصر. 44- ابن ماجة أبو عبد الله محمد بن يزيد القزويني (المتوفى: 273هـ)، (2009م)، سنن ابن ماجة، تحقيق شعيب الأرنؤوط ورفاقه، دار الرسالة العالمية، الطبعة الأولى. 45- مازن المبارك(1981م): اللغة العربية في التعليم العالي والبحث العلمي، مؤسسة الرسالة.

46- ماهر صبري، وصفاء سلطان، و أميرة الثافعي(2012م): "برنامج تدريبي مفترح لعلاج الأخطاء المنهجية و اللغوية الثائعة في تقارير بحوث التربية العلمية المنشورة بالمملكة العربية السعودية" در اسات عربية في التربية و علم النفس، العدد(24)، الجزء

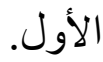
47- مجمع اللغة العربية بالقاهرة(1989م)، القرار ات المجمعية في الألفاظ و الأساليب من 1934 - 1987م، الهيئة العامة لشؤون المطابع الأميرية، مصر. 48- مجمع اللغة العربية بالقاهرة(د.ت)، المعجم الوسيط، دار الدعوة، المكتبة الثاملة الإلكترونية. 49- محمد العدناني(1973م): معجم الأخطاء الثائعة، مكثبة لبنان، بيروت. 50- محمد تقي الدين الهلالي(د.ت): تقويم اللسانين، بموقع المؤلف الإلكتروني: /http://www.alhilali.net

51- محمد جابر خلف الله (2017): فاعلية اختلاف حجم المجموعات المتزامنة بالفصول الافتراضية في تتمية مهارات إنتاج الاختبارات الإلكترونية والاتجاهات نحو التقنية لدى أعضاء هيئة التدري، مجلة البحث العلمي في التربية (كلية البنات جامعة عين شم)، العدد 18. (20) 
مجلة الجمعية المصرية للكمبيوتز التعليمي

52- محمد عبد الله صالح أبو الرب(2005م): "الأخطاء اللغوية في ضوء علم اللغة النة

التطبيقي"، دار وائل للنشر، عمان، الأردن، الطبعة الأولى.

53ـ محمود إسماعيل صيني، و إسحاق محمد الأمين(1982م)، التقابل اللغوي وتحليل الأخطاء، عمادة شؤون المكتبات، جامعة الملك سعود، الرياض، السعودية، الطبعة

الأولى.

54- محمود فهمي حجازي(1992م)، النظريات الحديثة في علم اللغة وتطبيقاتها في تعليم العربية على المستوى الجامعي، مجلة التعريب، دمثق، سوريا، العدد (4)، ديسمبر، ص(92-63).

55- مصطفى بن محمد سليم الغلاييني(1993م)، جامع الدروس العربية، المكتبة العصرية، صيدا- بيروت، لبنان، الطبعة الثامنة و العشرون.

56- مصطفى جو اد(2001م): قل ولا تقل، دار الهدى للتقافة و النشر، دمشق، سوريا.

57- معهد اللغة العربية لغير الناطقين بها(د.ت): الأخطاء اللغوية التحريرية لطلاب المستوى المتقدم في معهد اللغة العربية بجامعة أم القرى، مكة المكرمة، المملكة العربية السعودية.

58- ابن مكي الصقلي(1990م): تثقيف اللسان وتلقيح الجنان، قدم له وقابل مخطوطاته وضبطه مصطفى عبد القادر عطا، دار الكتب العلمية، بيروت لبنان، ط الأولى. 59- منال نبيل قاسم السعدي اليافعي(2016)، الأخطاء التركيبية لاى متعلمي اللغة العربية: طلبة برنامج تعليم اللغة العربية للناطقين بغير ها بجامعة قطر أنموذجا (ماجستير). جامعة قطر. كلية الآداب و العلوم، قطر .تم استرجاعه من .search.shamaa.org 60- ناصف يمين(1999م)، المعجم المفصل في الإملاء، دار الكتب العلمية، بيروت، لبنان، الطبعة الر ابعة.

61- نهاد الموسى(1984م): مقدمة في علم تعليم اللغة العربية، دار العلوم للتحقيق والطباعة و النشر، بيروت، لبنان، ط الأولى.

62- نهاد الموسى(2007م): "اللغة العربية في العصر الحديث: قيم الثبوت وقوى التحول"، دار الشروق، عمَّان، ط الأولى. 
مجلة الجمعية المصرية للكمبيوتر التعليمي

63- هـ. دوجلاس براون(1994م)، أسس تعلم اللغة وتعليمها، ترجمة عبده الر اجحي،

و علي شعبان، دار النهضة العربية للطباعة والنشر ، بيروت، لبنان.

64- هكتر هامرلي(1994م)، النظرية التكاملية في تدريس اللغات ونتائجها العملية، ترجمة

$$
\text { راثد الدويش، جامعة الملك سعود. }
$$

65- أبو هلال العسكري(د.ت)، الفروق اللغوية، حققه و علق عليه محمد إبر اهيم سليم، دار

$$
\text { العلم و الثقافة للنشر و التوزيع، القاهرة، مصر. }
$$

66- يوكي سوريادارما(2015م)، المقارنة بين علم اللغة التقابلي وتحليل الأخطاء، مجلة

$$
\text { لسان الضـاد، المجلد الثاني العدد الأول، شهر إبريل. }
$$

67- $\quad$ Alonso, L. \& Yuste, R. ( 2015). Constructing a grounded theory of e-learning assessment. Journal of Educational Computing Research, 53(3), 315-344.

68- $\quad$ Cigdem, H. \& Oncu, S. (2015). E-Assessment adaptation at a Military Vocational College: Student Perceptions. EURASIA. Journal of Mathematics, Science \& Technology Education, 11(5), 971-988.

69- $\quad$ Mora, C.; Sancho-Bru, L.; Iserte, L.; Sanchez, T. (2012). An E-Assessment approach for evaluation in engineering overcrowded groups. Computers \& Education, 59 (2), 732-740. 70- lamas, M.; Fernandez-Iglesias, M.; Gonzalez-Tato, J. \& Mikic-Fonte, A. (2013). Blended E-Assessment: Migrating Classical Exams to the Digital World. Computers \& Education, 62 (3),72-87. 
مجلة الجمعية المصرية للكمبيوتر التعليمي

\title{
Language errors in test questions at the University of Qassim in the light of applied languistics "paper and electronic tests"
}

\author{
Dr. Jamal bin Mustafa Sheta \\ Assistant Professor of Linguistics, Faculty of Science and Arts, \\ Unaizah,
} Qassim University - Kingdom of Saudi Arabia

\section{Abstract:}

The study aims to find ways towards accurate formulation of test questions and their linguistic validity. Up to the student's correct understanding of the test questions; In order to achieve the overall quality of the university educational product, in light of applied linguistics in the fields of language teaching and error analysis; It is a standard analytical descriptive study, by monitoring linguistic errors in test questions, analyzing and classifying them, stating their causes, and proposing the best ways to address and avoid them later. The professor is sure to focus on what is required of the question; Which may lead to neglecting the linguistic aspect of it or being overlooked. The required question does not disappear in the minds of the students. The study sample and its limits were from Qassim University tests at Buraidah Community Colleges, Sharia and Islamic Studies, the Arabic language, and the Faculties of Science and Arts, Qassim University. In the years from 1429/28 AH until the second semester of $1441 \mathrm{AH}$; To ensure the diversity of the major, the diversity of the students and the diversity of the questioners The researcher also conducted a questionnaire to survey the views of Qassim University students in $1441 \mathrm{AH}$, and it was distributed electronically, and (1084) students from all the university's colleges interacted with it, both theoretical and scientific. The study dealt with Paper and electronic tests through Three sections, the first: the reasons that led to the occurrence of linguistic errors in the test questions, and the second: the collection of errors and their classification into phonemic, morphological, grammatical and semantic errors, and correcting them. And the third: setting up two strategic plans for treatment, one of which is quick to implement, and falls on the responsibility of the administrative leaderships at the university, and the other is implemented - in the long term - during language teaching. The study found that there are many written errors in the tests, and that they affect the students' performance of those tests, and that the speedy writing of the questions, forgetting the rule, indifference in the wording, the wrong measurement, and the overlap of the dialect with the language - are the reasons that led to the occurrence of linguistic errors in the tests, And based on that means of treatment.

KeyWords: tests, electronic , errors, Applied Linguistics. 